Anderson Basilio Beserra

\title{
A Adaptação Quimiotática e a Estrutura da Dinâmica da Metilização
}





\section{Universidade de Brasília}

Anderson Basilio Beserra

\section{A Adaptação Quimiotática e a Estrutura da Dinâmica da Metilização}

Estudo matemático e computacional dos efeitos do número de sítios metílicos e de sua ordem de preenchimento na adaptação quimiotática da E. Coli.

Universidade de Brasília - UNB

Programa de Pós-Graduação

Orientador: Prof. Dr. Bernardo de Assunção Mello

Brasil

2014 
Anderson Basilio Beserra

A Adaptação Quimiotática e a Estrutura da Dinâmica da Metilização/ Anderson Basilio Beserra. - Brasil, 2014-

77 p. : il. (algumas color.) ; $30 \mathrm{~cm}$.

Orientador: Prof. Dr. Bernardo de Assunção Mello

Dissertação (Mestrado) - Universidade de Brasília - UNB

Programa de Pós-Graduação, 2014.

1. Quimiotaxia bacteriana. 2. Adaptação perfeita. 3. Modelo sequecial e não-sequencial de metilização I. Prof. Dr. Bernardo de Assunção Mello. II. Universidade de Brasília. III. Pos-graduação de Física. IV. A Adaptação Quimiotática e a Estrutura da Dinâmica da Metilização 
"A Adaptação Quimiotática e a Estrutura da Dinâmica da Metilização"

Por

\section{Anderson Basilio Beserra}

Dissertação submetida ao Instituto de Física da Universidade de Brasília como parte dos requisitos para obtenção do grau de Mestre em Física.

Aprovado por:

Prof. Bernardo de Assunção Mello

IF/UnB

Prof. André Luiz Almeida Penna

FGA/UnB

Prof. Fernando Albuquerque de Oliveira

$\mathrm{IF} / \mathrm{UnB}$

Prof. Dr. Fernando de Oliveira Albuquerque

Coordenador de Pós-graduação

Instituto de Física 

Dedico a todas pessoas que através do estudo conseguiram lograr sucesso em suas vidas. 



\section{Agradecimentos}

Gostaria de agradecer a Deus por ter me feito aceitar as dificuldades e através delas buscar sempre algo melhor e digno;

Aos professores que tive durante está dura caminhada, em especial ao meu orientador Prof. Dr. Bernardo de Assunção Mello que foi de fundamental importância para a conclusão deste trabalho, sempre me orientando da maneira mais correta e que, sem sombra de dúvidas, é um grande amigo;

Aos meus amigos de trabalho Marcos Valério Madureira e Marcos Aquiles Landim Viegas do Departamento de Estradas de Rodagem - DER/DF, em especial ao meu amigo Flávio Sena Suzano, que com seu apoio e compreensão sempre esteve ao meu lado, tornando essa caminhada mais tranquila;

Aos meus filhos, Guilherme e Breno, que são os verdadeiros motivos de tanta dedicação;

Ao meu amor que sempre foi minha maior inspiração, sendo a razão pela qual dedico todos os meus esforços e que sem ela não chegaria até este lugar (Te Amo Muito);

À minha mãe, que mesmo não estando mais presente, foi quem me ensinou a ser quem sou hoje. 

"A mente que se abre a uma idéia, jamais voltará ao seu tamanho original".

(Albert Einstein) 



\section{Resumo}

O estudo da quimiotaxia bacteriana é um assunto que está em intenso desenvolvimento, tendo em vista que ainda possui diversos fenômenos que não foram completamente esclarecidos. Neste trabalho, estudamos os motivos pelo quais se podem relacionar o modelo de Ising com a interação entre os receptores, dando uma visão matemática. Analisamos o efeito da ordem de metilização e desmetilização na dinâmica da quimiotaxia da bactéria Escherichia coli. Por meio de simulações Monte Carlo determinamos como a adaptação quimiotática em resposta à mudanças na concentração de estímulos é afetada pelas características dos modelos de metilização sequencial e não sequencial. Os resultados deste estudo comprovaram que a perfeita adaptação somente é conseguida usando o modelo sequencial de adição de grupos metílicos nos receptores e que no modelo não-sequencial não é capaz de fazer o sistema se adaptar. Os resultados mostram também que o número de sítios metílicos da E. Coli (4 sítios) é o mais vantajoso do ponto de vista evolutivo.

Palavras-chaves: quimiotaxia bactériana. adaptação perfeita. modelo sequecial e nãosequencial de metilização. 



\section{Abstract}

Bacterial chemotaxis is a research topic under fast development presently, with several phenomena not yet fully understood. In this work we study the connections between the Ising model and the cellular receptors interaction, from a mathematical point of view. We analyse the effects of receptor methylation and demethylation order in the chemotaxis dynamics of the Escherichia coli bacterium. We use Monte Carlo simulation to determine how the chemotatic adaptation in response to changes in stimulus concentration is affected by the characteristics of the sequential and non-sequential methlylation models. Our results show that the perfect adaptation can only be attained in the sequential methylation model, under certain conditions, and that the non-sequential model doesn't adapt. We also show that the number of methylic sites found in the Escherichia coli (4 sites) is the most advantageous from the evolution point of view.

Key-words: bacterial chemotaxis. perfect adaptation. sequential and non-sequential pattern of methylation. 



\section{Lista de ilustrações}

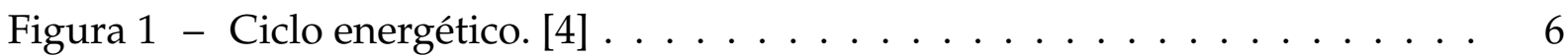

Figura 2 - Função $\frac{[L]}{([L]+K)}$ em gráfico linear (a) e monolog (b). . . . . . . . . 8

Figura 3 - Imagem virtual da bactéria Escherichia Coli mostrando os flagelos.[11] 10

Figura 4 - Comportamento do nado da E. Coli. A) sem estímulo; B) com estímulo

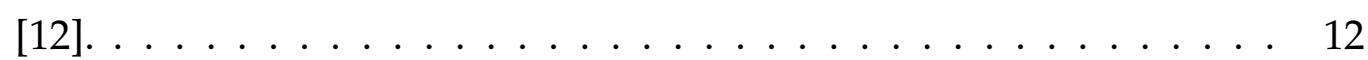

Figura 5 - Representação do movimento: A) das bactérias; B) e C) das células eucariontes $[11] \ldots \ldots \ldots \ldots$. . . . . . . . . . . . . . 14

Figura 6 - Ilustração das vias de sinalização da Escherichia Coli, demostrando as comunicações feitas entre CheA, CheW, CheY, CheR, CheB e CheZ; suas devidas fosforizações em CheA e CheY e desfosforizações devido a influência dos CheB e CheZ (SOURJIK, 2004). . . . . . . . . . . 15

Figura 7 - Movimento de natação e giro das bactérias ([16], com adaptações do

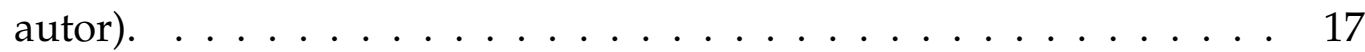

Figura 8 - Movimento quimiotático das bactérias [16] . . . . . . . . . . . 18

Figura 9 - Sítios metílicos dos receptores da E. Coli: sitios ocupados (círculo escuro), sítios vagos (círculo claro) [9]. . . . . . . . . . . . . . .

Figura 10 - Esquema simplificado da interação entres os receptores, as proteínas (CheA, CheW, CheB, CheR, CheY e CheZ) e o motor flagelar (FliM) durante o processo de transdução de sinal quimiotático na Bactéria [9]. 19

Figura 11 - Demonstração do Esquema interno da bactéria, mostrando a adição e subtração dos grupos metílicos: a) receptor esta ativo e na ausência de nutrientes conectados, CheR adiciona e CheB retira os grupos metílicos em quantidades aproximadamente iguais; $b$ ) na presença de uma grande concentração de nutrientes, CheR faz a metilização sem a utilização de cheB; c) após adaptado Che-B volta a retirar grupos metílicos e o número de grupos metílicos se estabiliza num nível mais alto [20]

Figura 12 - Comportamento da atividade em meio a uma concentração de estímulo. Adaptação perfeita, linha preta [21]. . . . . . . . . . . . . .

Figura 13 - Diferença entre os modelos MWC e Ising. No modelo MWC a interação é apenas entre os receptores do mesmo grupo. No modelo de ising a interação é dada com os vizinhos mais próximos, não existe

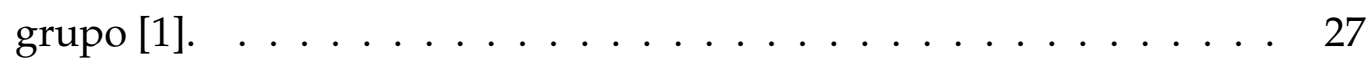

Figura 14 - Esquema de metilização sequencial. . . . . . . . . . . . . . . 32

Figura 15 - Esquema de metilização não sequencial. . . . . . . . . . . . . . . 33 
Figura 16 - Razão de receptores ocupados por moléculas de ligante, em função da concentração de ligante do ambiente [32] . . . . . . . . . . . 38

Figura 17 - Razão de receptores ocupados por moléculas de ligante, em função da concentração de ligante do ambiente [32], com adaptação. . . . . .

Figura 18 - Esquema simplificado do modelo sequencial, mostrando a população de receptores e seus possíveis caminhos após metilizados/desmetilizados, lembrando que CheR só age em receptores inativos e CheB nos ativos. 40

Figura 19 - Esquema simplificado de uma simulação utilizando o método Monte Carlo [34].

Figura 20 - Comportamento da atividade sob a influência da concentração de ligantes, dos receptores ligados (conectados) e dos grupos metílicos, onde a atividade se refere a média dos receptores ativos, o $[L 0]$ representa a concentração de estímulos externos, "Rec. Lig"é a média dos receptores ligados e $M 0, M 1, M 2, M 3, M 4$ são frações dos receptores com cada número de grupos metílicos. . . . . . . . . . . . . . . 55

Figura 21 - Atividade dos receptores, Concentração de Estímulo. . . . . . . . . . . . 56

Figura 22 - Atividade dos receptores e receptores ligados aos ligantes. . . . . . . 57

Figura 23 - Ampliação da figura 22 entre o intervalo $t=35$ a $t=50 \ldots \ldots$. . . 59

Figura 24 - Comparação entre a atividade por sítios de metilização. . . . . . . . . 60

Figura 25 - Distribuição dos níveis após a adaptação, obtidos dos valores médios dos 20 últimos pontos antes de cada mudança de concentração da figura 20, da esquerda para a direita, as colunas de cada conjunto representam a ocupação dos receptores $M 0, M 1, M 2, M 3$ e $M 4$, com a concentração de estímulo no intervalo de $10^{-1}$ a $10^{8} \ldots$. . . . . . .

Figura 26 - Comportamento do sistema com $m_{0}=2$ : a) gráfico com a atividade e a metilização; b) distribuição da população de $M 0, M 1, M 2, M 3$ e $M 4$, entre o intervalo de concentração de estímulo de $10^{-1}$ a $10^{8}$. . . . . .

Figura 27 - Comportamento do sistema com $m_{0}=3$ : a) gráfico com a atividade e a metilização; b) distribuição da população de $M 0, M 1, M 2, M 3$ e $M 4$, entre o intervalo de concentração de estímulo de $10^{-1}$ a $10^{8}$. . . . . .

Figura 28 - Comportamento do sistema com 3 sítios de metilização: a) Refere-se ao gráfico geral com todas as grandezas $a,[L 0]$, Rec.lig e sítios metíli$\cos M 0, M 1, M 2, M 3 ; b)$ Histograma com a ocupação das populações de cada sítios metílicos.

Figura 29 - Comportamento do sistema com 6 sítios de metilização: a) Refere-se ao gráfico geral com todas as grandezas $a,[L 0]$, Rec.lig e sítios metílicos $M 0, M 1, M 2, M 3, M 4, M 5, M 6 ; b)$ Histograma com a ocupação das populações dos sítios metílicos. 
Figura 30 - Demonstração do sistema não-sequencial: a) Refere-se ao gráfico geral com todas as grandezas b) Histograma com a ocupação das populações de cada sítio metílico. . . . . . . . . . . . . . . . . . . 69 



\section{Lista de tabelas}

Tabela 1 - Variedade da Motilidade nas Bactérias [12] . . . . . . . . . . 16

Tabela 2 - Parâmetros usados na simulação . . . . . . . . . . . . . 47 



\section{Lista de abreviaturas e siglas}

$\alpha_{q}$

$\Delta E$

$\langle m\rangle_{q}$

$\mu_{q}^{A}$

$\vec{m}$

$a$

$C_{q q^{\prime}}$

E

$E_{q m}^{M}$

$E_{q}^{C}$

$f_{m}(m)$

$H_{q \vec{m} l a}$

I

K

$K_{a}$

$K_{a}[L]$

$K_{B} T$

$k_{q 0} ; k_{q 1}$
Concentração de ligantes, página 6

Concentração de ligante para um tipo de quimioreceptor, página 33

Concentração de proteínas, página 6

Concentração de Proteínas-Ligantes, página 6

Mudança na diferença da energia entre os estados ativos e inativos, página 35

Variação de energia no passo Monte Carlo, página 48

Metilização média, página 41

Potencial químico no passo Monte Carlo do estado ativo, página 32

Vetor do nível de metilização no modelo não-sequencial, página 31

Estado de atividade do receptor, página 32

Constante de acoplamento entre receptores, página 35

Energia de determinado estado do sistema, página 29

Energia dos receptores com dependência dos grupos metilicos, página 32

Energia dos receptores com dependência nas interações dos receptores vizinhos, página 32

Diferença de energia livre entre o estado ativo e inativo, página 28

Energia individual de cada receptor, página 32

Constante de interação no modelo de Ising, página 30

Contante de dissociação, página 7

Constante de associação, página 7

Concentração de ligantes livres, página 7

Constante de Bolltzman vezes a temperatura, página 32

Taxa de ligação dos ligantes ao receptor, página 33 
CheB

CheR

CheW

CheY

CheZ

FLiM

FRET
Constante de dissociação dos ligantes aos receptores ativos, página 34 Estado de ligação ou não do ligante ao receptor, página 31

Nível de metilização, página 31

Receptor sem grupo metílico, página 60

Receptor com 1 grupo metílico, página 60

Receptor com 2 grupo metílico, página 60

Receptor com 3 grupo metílico, página 60

Receptor com 4 grupo metílico, página 60

Origem do nível de metilização, página 35

Número de receptores da simulação, página 68

Probabilidade para quatro estados (ativo, inativo, com ligante e sem ligante), página 28

Probabilida do estado descrito por q,m,l,a, página 32

população dos receptores do tipo $q$ com $m$ grupos metílicos, página 40

Tipo de quimioreceptores, página 31

Receptor no estado ligado, ou desligado a ligantes e ativo, ou inativo, página 31

Adenosina trifosfato, página 5

Proteína quimiotática A, página 18

Proteína quimiotática $\mathrm{B}$, página 18

Proteína quimiotática $\mathrm{R}$, página 18

Proteína quimiotática $\mathrm{W}$, página 18

Proteína quimiotática $Y$, página 18

Proteína quimiotática $Z$, página 18

Motor-flagelar, página 26

Fluorecence Resonance Energy Transfer, página 27

Monte Carlo, página 36 
MCP's Methyl-accepting chemotaxis proteins, página 11

MWC Monod, Wyman e Changeux, página 26 



\section{Sumário}

Introdução $\ldots \ldots \ldots \ldots \ldots \ldots \ldots \ldots$

I DESCRIÇÃO DO PROBLEMA 3

$1 \quad$ INTRODUÇÃO TEÓRICA $\ldots \ldots \ldots \ldots \ldots$

$1.1 \quad$ Vias metabólicas $\ldots \ldots \ldots \ldots \ldots \ldots \ldots$

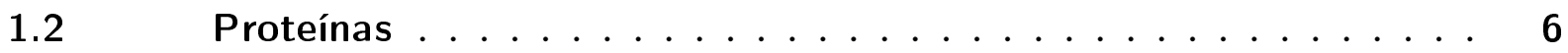

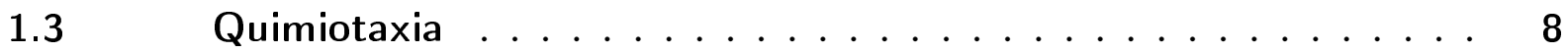

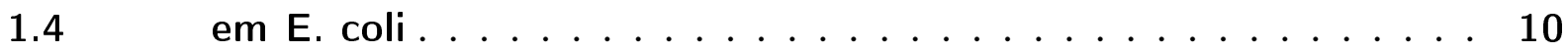

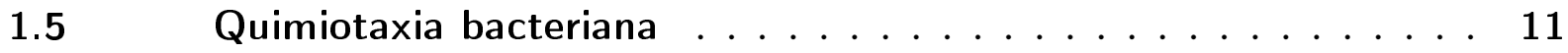

$1.6 \quad$ Mecanismo da quimiotaxia bacteriana . . . . . . . . . . 14

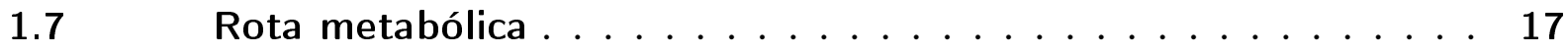

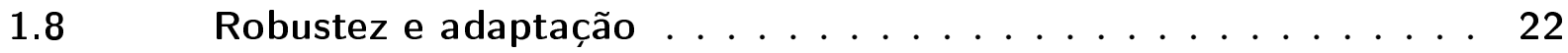

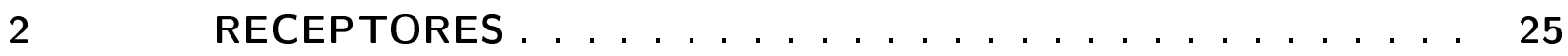

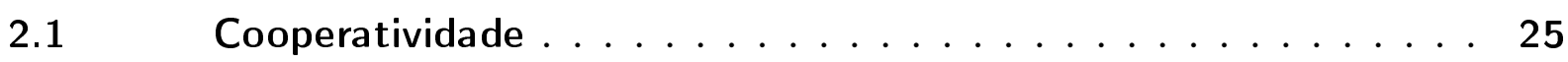

2.2 Comunicação e amplificação do sinal . . . . . . . . . . . 27

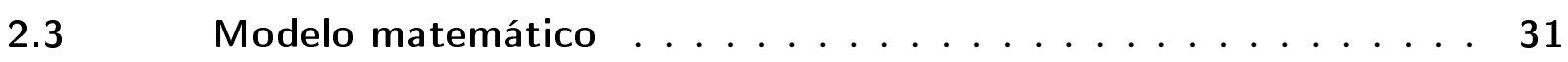

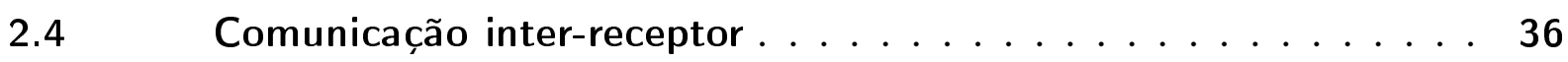

$2.5 \quad$ Adaptação perfeita $\ldots \ldots \ldots \ldots \ldots \ldots \ldots$

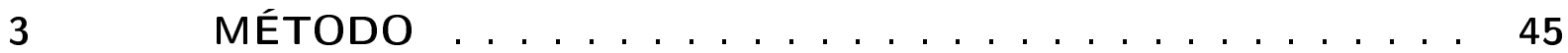

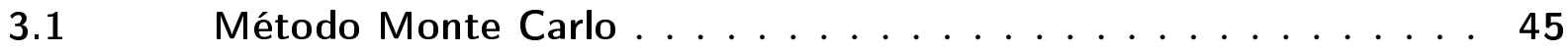

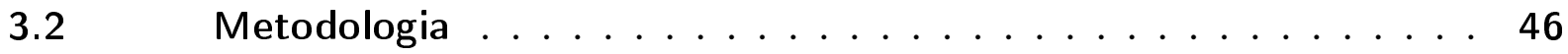

$\begin{array}{lll}\text { II } & \text { RESULTADOS } & 51\end{array}$

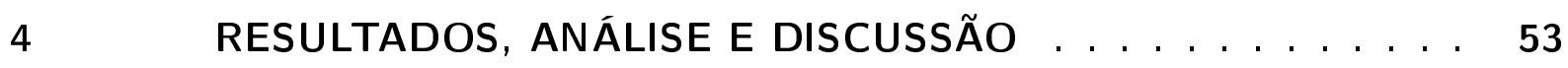

$4.1 \quad$ Atividade VS Concentração de Estímulos . . . . . . . . . 54

$4.2 \quad$ Atividade VS Receptores Ligados . . . . . . . . . . . . . 57

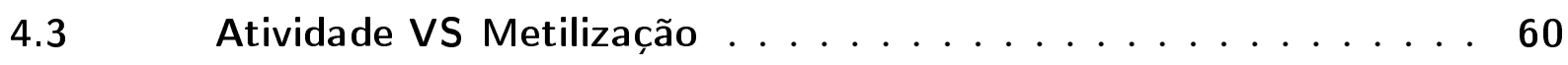

$4.4 \quad$ Efeitos do número de grupos metílicos . . . . . . . . . . 63

$4.5 \quad$ Modelo Não-Sequencial $\ldots \ldots \ldots \ldots \ldots$ 
Referências . 


\section{Introdução}

O deslocamento dos seres vivos em direção a um ambiente mais favorável é um fenômeno que pode ser visto em vários tipos de animais. Como exemplo, podemos citar os seres humanos e os animais irracionais. O primeiro, com sua capacidade motora e desenvolvimento cognitivo consegue traçar metas e objetivos com o intuito de saciar suas necessidades. O segundo, os animais irracionais, também conseguem traçar metas e através de seus instintos abaterem suas presas. No entanto, os seres humanos e os animais irracionais são dotados de capacidade cognitiva. Mas o que dizer de seres vivos que são totalmente desprovidos de um tipo de inteligência e sem qualquer capacidade de raciocínio? Como eles conseguem saber quais os nutrientes são necessários para o seu desenvolvimento? Como são capazes de se orientar em direção de seus alimentos (atratores) e se afastar de ambientes hostis (repelentes)? Com o desenvolvimento da ciência e consequentemente da microscopia, os movimentos das bactérias começaram a ser identificados e despertaram o interesse dos pesquisadores. Assim, com essa característica de buscar nutrientes e se afastar de ambientes hostis, surge a necessidade de entender os motivos e os fenômenos físicos que poderiam estar envolvidos nesse processo.

Diretamente ligada a isso, está a quimiotaxia que é um fenômeno físico em que as células bacterianas têm a propriedade de sentir o ambiente químico e orientar os seus movimentos em direção aos atraentes e se afastar dos repelentes. Este é um dos sistemas de transdução de sinais mais bem estudados na Biologia [1].

Sendo assim, em nossos estudos daremos ênfase a bactéria Escherichia coli (E. coli), em especial a processos relacionados aos efeitos da ordem da metilização nos receptores trans-membráticos na quimiotaxia das bactérias. 

Parte I

Descrição do problema 



\section{Introdução teórica}

\subsection{Vias metabólicas}

O amplo campo de estudo dos micro-organismos possibilita aprofundar no assunto e conhecê-los com mais qualidade, quando comparado com a complexidade dos estudos envolvendo animais e vegetais. Uma forma de poder compreender esses microorganismos é entendendo o mecanismo por trás de cada função vital. Estes mecanismos químicos são as Vias Metabólicas Celulares constituídas por um emaranhado de reações químicas que se superpõem e se completam formando um complexo e preciso ciclo químico de consumo de reagente (substratos) e formação de produtos [2]. As vias metabólicas podem ser entendidas como uma série de reações químicas que fornecem um produto, sendo que, necessariamente, esse produto deve ser usado na próxima reação, onde sempre deve haver, em cada via, uma reação irreversível, assegurando que esta reação não seja apenas uma dissipação de energia. Para Corsino (2009), as vias metabólicas consistem em uma série de reações enzimáticas relacionadas que resultam em um produto, sendo que existem mais de 2.000 reações metabólicas conhecidas, catalisadas por diferentes enzimas.

A fonte energética da célula é uma molécula chamada de ATP (Adenosina Trifosfato), presente em diversos processos biológicos, sendo criada e aproveitada durante o metabolismo e utilizada nas diversas vias metabólicas como agente de criação de moléculas complexas (Figura 1). As diversas vias metabólicas relacionam-se entre si, permitindo uma regulação adequada. Este relacionamento envolve a regulação enzimática de cada uma das vias [3].

Existe grandes variedades de vias metabólicas, sendo que, nos humanos, podemos citar: Glicólise; Ciclo de Krebs; Fosforilação Oxidativa; Via das Pentoses-Fosfato; Ciclo da Ureia; beta-oxidação dos ácidos graxos e Neoglicogenese [3]. Importante salientar que as vias metabólicas devem ser estudadas de maneira integrada, pois ocorrem dentro de uma entidade dinâmica e programada para a sobrevivência da célula [2]. 


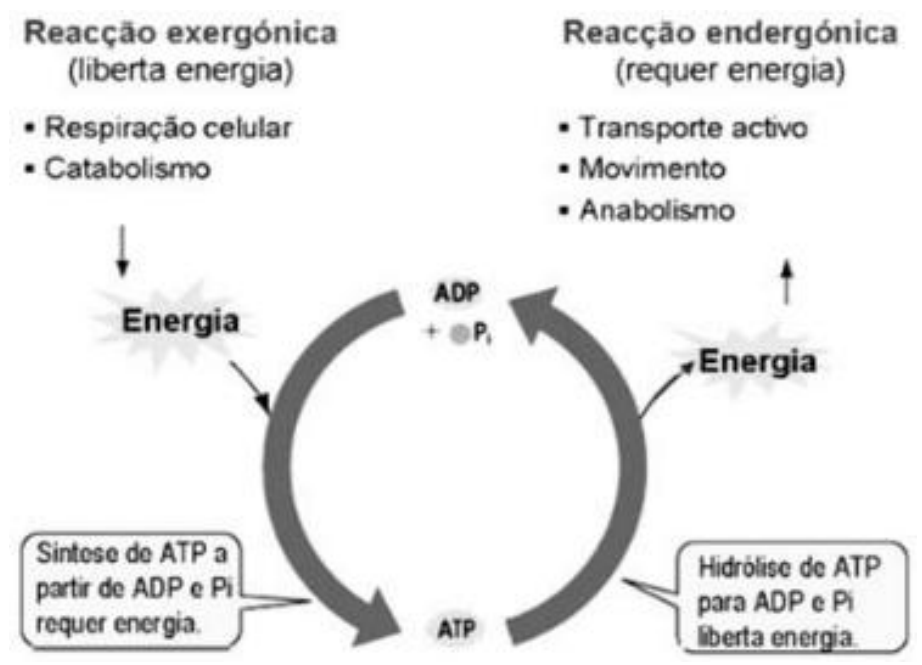

Figura 1 - Ciclo energético. [4]

\subsection{Proteínas}

O nome proteínas vem da palavra grega "protos" que significa "a primeira" ou a "mais importante". As proteínas são as biomoléculas mais abundantes nas células vivas e são os instrumentos moleculares por meio dos quais as informações genéticas são expressas [5], estando presente em todas as partes das células. As proteínas são polímeros, fundamentalmente composta por aminoácidos, sendo que apenas 20 aminoácidos são responsáveis para formarem todas as proteínas, seja qual for a forma de vida [6]. As proteínas são moléculas dinâmicas cujas funções dependem, quase invariavelmente, das interações com outras moléculas.

As funções de muitas proteínas são envolvidas por ligações reversíveis com outras moléculas ou proteínas, a essa ligação reversível se dá o nome de ligante [5]. Esse processo é fundamental para a vida, pois permite que o organismo possa responder as mudanças ambientais de maneira rápida e reversível.

Nelson (2002) mostra que essas interações, proteínas-ligante, podem ser descritas quantitativamente, onde, geralmente, uma ligação reversível pode ser mostrada como uma expressão de equilíbrio:

$$
P+L \Longleftrightarrow P L
$$

Sendo essa reação caracterizada por uma constante de equilíbrio de associação, de unidade $M^{-1}$, representada pela razão das concetrações de Proteínas-Ligante $[P L]$ com o valor das concentrações unitário das proteínas $[P]$ e ligantes livres $[L]$ em 
equilíbrio:

$$
K_{a}=\frac{[P L]}{[P][L]}
$$

onde $K_{a}$ (constante de associação) constitui a afinidade do ligante pela proteína. Quanto maior o valor de $K_{a}$ maior a afinidade. $\mathrm{O}$ quociente entre a proteína ligada com a proteína pura é proporcional à concentração do ligante livre $K_{a}[L]$ :

$$
K_{a}[L]=\frac{[P L]}{[P]}
$$

Quando a concentração de ligantes é muito maior que a concentração de sitio para ligação, a associação do ligante não muda a concentração de ligante livre $[L]$, deixando-o constante [5]. Assim, a fração de proteínas ligadas pode ser dado por $\theta$ da seguinte maneira:

$$
\theta=\frac{[P L]}{[P L]+[P]}
$$

onde $[P L]$ o número de sítios ligados e $[P L]+[P]$ é o número total de sítios (ligados e desligados). Usando a equação 1.3 na equação 1.4 , temos:

$$
\theta=\frac{K_{a}[P][L]}{K_{a}[P][L]+[P]}=\frac{K_{a}[L]}{K_{a}[L]+1}=\frac{[L]}{[L]+\frac{1}{K_{a}}}
$$

Assim como a constante de associação $K_{a}$, existe também a constante de dissociação $K$ que está relacionada com os ligantes não ligados aos receptores. $K$ é mais comumente encontrada na literatura. Dessa forma, considerando a constante de dissociação $K$ como $K=\frac{1}{K_{a}}$, as equações 1.3 e a equação 1.4 podem ser escritas da seguinte forma:

$$
\begin{gathered}
K=\frac{[P][L]}{[P L]} \\
{[P L]=\frac{[P][L]}{K}} \\
\theta=\frac{[L]}{[L]+K}
\end{gathered}
$$

a equação 1.8 mostra que, se $[L]$ for igual a $K$, metade dos sítios de ligação estará ocupado [5].

É interessante lembrar que, para baixas concentrações, $[L] \ll K$, a equação 1.8 pode ser descrita $\operatorname{como} \theta=\frac{[L]}{K}$, ou seja, o número de proteínas ligadas é proporcional à $[L]$. A medida que $[L]$ se aproxima de $K$, o comportamento torna-se não linear, como 


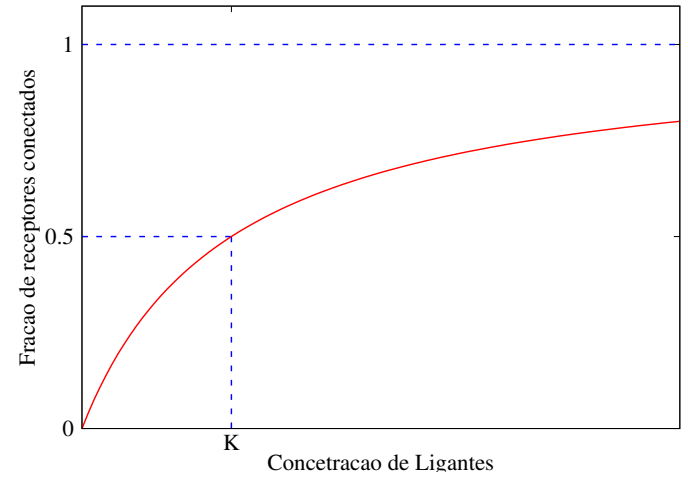

(a)

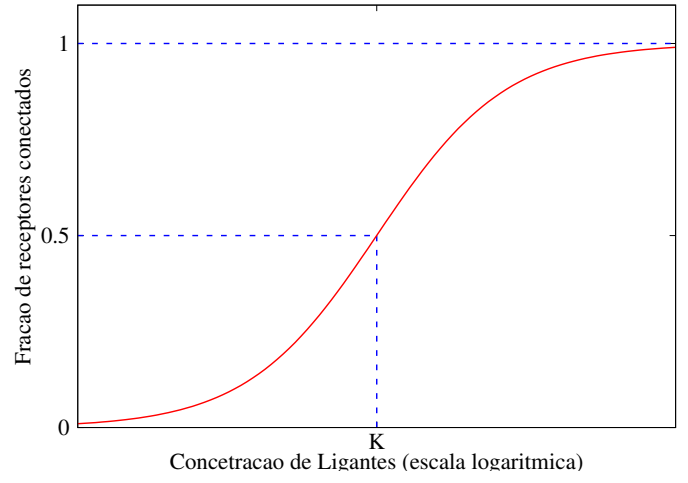

(b)

Figura 2 - Função $\frac{[L]}{([L]+K)}$ em gráfico linear (a) e monolog $(\mathrm{b})$.

pode ser visto na figura $2 \mathrm{a}$. A figura $2 \mathrm{~b}$ evidencia que $K$ define a escala de valores de $[L]$.

As proteínas também são responsáveis pela existência de varias células, ou melhor, a existência de varias células diferentes, em um mesmo organismo, é proveniente da sintetização e acumulação de proteínas diferentes. O responsável por este fenômeno é chamado de expressões gênicas, que é o processo pelo qual uma informação, codificada por um determinado gene, vai ser decodificada em uma proteína. Em organismos procariontes, como as bactérias, a regulação da expressão gênica, faz com que as células se ajustem ao seu ambiente.

\subsection{Quimiotaxia}

A importância da quimiotaxia está diretamente ligada a diversos comportamentos dos seres vivos e que muitas vezes não são evidenciadas visualmente. Como exemplo, podemos citar: o direcionamento do espermatozóide em direção ao óvulo; a orientação das células brancas para combater alguma inflamação e a locomoção dos microorganismos em busca de alimentos [7]. Tudo isso é fonte de estudo é já amplamente caracterizado como um comportamento que é um dos produtos da quimiotaxia. Em um sentido amplo, podemos dizer que a quimiotaxia é um movimento inerente a alguns seres vivos, tais como organismos unicelulares, insetos e mamíferos, que envolvem processos químicos, com o objetivo de buscar o melhor local para sobrevivência ou se afastar de locais desfavoráveis. Nas bactérias podemos citar a busca pelos nutrientes e os afastamentos dos repelentes. Nos insetos, a quimiotaxia está presente na condição de 
se agruparem em bandos visando condições mais agradáveis, ou para reprodução, um exemplo desse último caso é o bicho da seda fêmea que exala um cheiro (feromônio), identificado pela antena do bicho da seda macho que persegue maior concentração desse feromônio fazendo ele se deslocar em sua direção [8]. Outro exemplo são os mamíferos, que com este processo químico evitam predadores e buscam condições necessárias para propagação da espécie.

O processo da quimiotaxia exerce um papel crucial nos mecanismos biológicos dos seres vivos e, em alguns casos, este processo é, de certa forma, o mesmo para varias espécies. Nos animais e nos seres humanos, as infecções são responsáveis por grande parte das doenças e acabam levando a um grande numero de mortes. Neste sentido, a quimiotaxia exerce importante papel, sendo um exemplo, o combate que nosso próprio corpo exerce quando se vê sob a ameaça de alguma infecção. Evidências sugerem que os leucócitos no sangue se movimentam em direção a inflamação bacteriana para combatêla [8]. Todo esse processo de quimiotaxia está diretamente ligado à concentração do estímulo, ou melhor, do gradiente químico da concentração destes estímulos (atraentes ou repelentes).

De forma geral, podemos dizer que a quimiotaxia é caracterizada por movimentos quimicamente direcionados e que é um processo natural dos seres vivos sejam eles racionais, irracionais, ou organismos sem sistema nervoso central, como por exemplo, as bactérias. Na literatura, a quimiotaxia é usada como um termo que designa o movimento de uma célula que pode ser tanto para se aproximar como para se distanciar de uma fonte de um produto químico. Esses movimentos de aproximação e distanciamento são conhecidos pelos nomes de quimiotaxia positiva (movimento de aproximação) e quimiotaxia negativa (movimento de distanciamento). No entanto, mesmo com toda a influência e importância da quimiotaxia na vida dos seres vivos mencionadas até aqui, o termo "quimiotaxia" é mais conhecido quando está relacionado aos movimentos das células. Sendo assim, fica evidente, pela abrangência dos conceitos e vasta aplicação de suas características, a importância da quimiotaxia para o desenvolvimento dos seres vivos. 


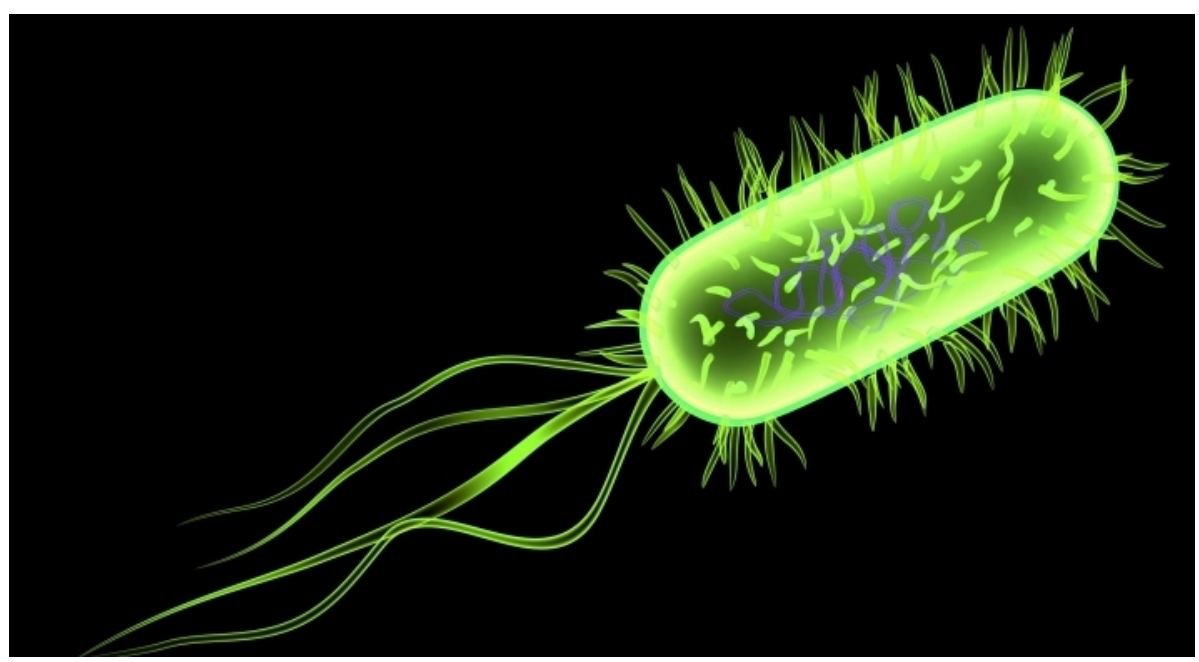

Figura 3 - Imagem virtual da bactéria Escherichia Coli mostrando os flagelos.[11]

\subsection{Escherichia Coli (E. Coli)}

A E. Coli é um organismo unicelular que tem como principal ambiente o intestino. De certa forma, a quantidade de estudos feitos com esta bactéria está ligada à simplicidade de suas características. Se comparadas com outras bactérias, podemos dizer que a $E$. Coli está para os biólogos assim como o átomo de hidrogênio está para os físicos. Conhecer o que acontece com ela certamente abrirá uma grande possibilidade de se entender as características das outras bactérias.

A E. coli é equipada por um conjunto de propulsores, conhecido como flagelos, filamento fino e helicoidais que se estendem para fora da célula (figura 3). O movimento dos flagelos podem ser feitos em dois sentindo: anti-horário e horário, sendo que estes sentidos são responsáveis pelo tipo de movimento que a bactéria irá seguir. Através da rotação de seus flagelos a E. Coli tem a capacidade de direcionar-se para a área mais propícia ao seu desenvolvimento (direção dos estímulo de atração). Se as condições não são favoráveis, movimenta os flagelos no sentido horário fazendo com que fiquem desordenados e provoquem uma mudança aleatória de direção. Com os movimentos dos flagelos no sentido anti-horário, eles formam um tipo de hélice, levando a deslocamentos mais prolongados em direção aos atratores [9]. Como resultado, a bactéria executa um passeio aleatório tendendo à maior concentração de atraente. Este mecanismo proporciona à bactéria a capacidade de seguir o gradiente de concentração química, isto é, a quimiotaxia [10].

Na bactéria E. Coli o movimento dos flagelos está diretamente ligado aos seus 
receptores celulares, pois o início de transmissão de informação, para que seja dada a ordem do sentido da rotação, depende se os receptores estão inativos (ocupados com algum tipo de nutriente) ou ativos (desocupados de nutrientes).

\subsection{Quimiotaxia bacteriana}

O fenômeno da quimiotaxia bacteriana foi descoberto por W. Engelmann e W. Pfeffer em 1880. No entanto, a investigação completa do fenômeno começou na década de 1960 com os estudos quantitativos, genéticos e bioquímicos de J. Adler [12]. Para Kugler (2009) a quimiotaxia bacteriana é um dos subsistemas biológicos mais bem conhecidos e que, de certa forma, acaba tornando alvo potencialmente promissor para modelagem computacional, seja na biologia, na química ou na física, onde nesta última área o estudo está caracterizado mais especificamente em seu comportamento físico (cinética) e reações causadas por ele.

Devido ao pequeno tamanho e relativa simplicidade das bactérias, a capacidade de se ajustar ao ambiente para conseguir suprir suas necessidades é, de certa forma, muito limitada. No entanto, ao invés de tentar se ajustar ao meio em que vivem, elas aparentemente adotaram a estratégia de se moverem de um ambiente para outro, o que faz com que, durante seu ciclo de vida, as bactérias frequentem diversos ambientes [12]. Por outro lado, as bactérias são incapazes de escolher os caminhos que elas devem nadar e de manter a natação em linha reta por mais de alguns segundos. Assim, se a bactérias estiverem se movendo na direção de um atraente químico, ou se afastando de um repelente, elas procuram nadar uma maior distância em linha reta com eventuais pequenas guinadas, mas sempre mantendo o caminho do atraente-químico. Do contrário, se estiverem se movendo em direção a um repelente químico, ou se afastando de um atrator, elas tendem a dar "guinadas" com mais frequência, buscando uma nova rota (Figura 4). Essa característica faz com que as bactérias usem um sensoriamento temporal, possuindo uma "memória", onde ela compara as informações passadas com as informações futuras para tomar uma decisão [7].

Na bactéria E. Coli alguns estímulos quimiotáticos se ligam diretamente nos receptores específicos, chamados de MCP's (methyl-accepting chemotaxis proteins) . Os MCP's são os identificadores das proteínas específicas para cada tipo de receptor. Outros estímulos fazem um percurso maior, passando antes por um receptor principal 


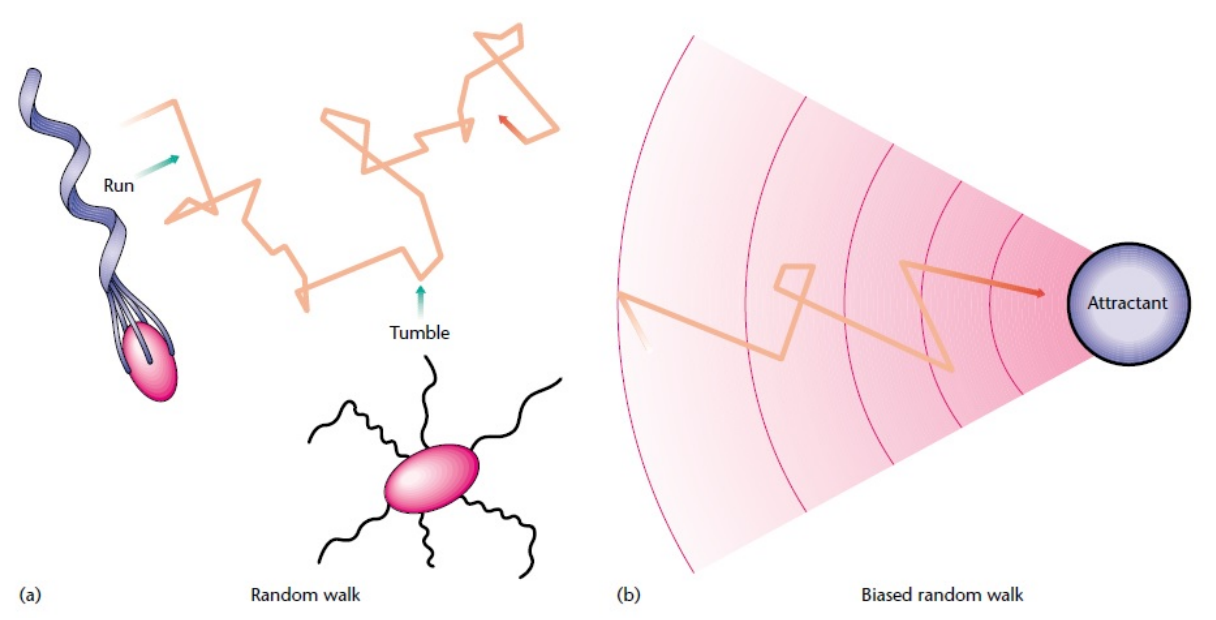

Figura 4 - Comportamento do nado da E. Coli. A) sem estímulo; B) com estímulo [12].

e somente depois se ligam ao receptor específico (EINSENBACH, 2004). Neste trabalho trataremos os $\mathrm{MCP}$ 's apenas como receptores.

A quimiotaxia bacteriana desempenha uma função muito importante, pois é através dela que as bactérias conseguem buscar alimento, ou fugir dos venenos. Estes estímulos são detectados por receptores, proteínas lineares que atravessam a membrana e tem um local de ligação na parte externa da bactéria. Cada bactéria possui uma capacidade de atração, ou adaptação a diferentes tipos de moléculas. Em uma determinada bactéria, cada receptor tem por sua natureza uma identidade com moléculas diferentes, ou seja, cada receptor tem uma molécula especifica para se ligar. Na bactéria Escherichia Coli (E. Coli), por exemplo, os receptores já são bem definidos em questão quantitativa, sendo no total cinco tipos de quimioreceptores: aspartato (Tar), serina (TSR), dipeptídios (TAP), ribose e galactose (TRG) e potencial redox (Aer), sendo encontrado em maior quantidade os receptores que tem mais afinidade de atração com os aminoácidos do tipo Tar e TSR. Já receptores que tenham maior afinidade com TAP, TRG e Aer são encontrados em menor quantidade na bactéria E. Coli [13]. A ligação de um atraente no receptor desencadeia uma série de respostas nas bactérias, sendo que a principal é o modo como ela vai se comportar, seja deslocando-se em direção ao local de maior concentração de atraentes, seja dando guinadas aleatórias e buscando locais de maior concentração de nutrientes.

Conforme Eisenbach (2004) menciona em seu trabalho, existem várias técnicas de se medir a "mobilidade" e a quimiotaxia das bactérias, tais como: o estabelecimento do gradiente do estímulo feito por difusão (passagem do local de maior concentração para 
o de menor); a migração da população do gradiente liquido previamente estabelecido; a formação de anel em uma placa de "agar" semissólida (utilizam a metabolização da bactérias com o atraente-químico) e o rastreamento de bactérias de nado livre, rotações dos flagelos.

Além dessas técnicas para se medir a quimiotaxia, mencionadas no paragrafo anterior, existe também a que trabalha com a variação temporal da concentração de ligantes. Ou seja, a bactéria, usando seus receptores, detecta o gradiente da concentração de ligantes que existe a sua volta e faz uma comparação com o que ja havia encontrado, assim, dependendo do resultado ela ou aumenta o número de guinadas, ou permanece nadando. Essa técnica é a que será utilizada nesse trabalho. Em determinado instante, a concentração de ligantes é alterada e os receptores irão se ligar, ou não aos atraentes químicos, dando origem aos processo quimiotático.

Embora o fenômeno da quimiotaxia bacteriana tenha sido descoberto há mais de um século atrás e da era moderna, com intensas investigações científicas, ter acontecido a mais de cindo décadas, os enigmas da importância da quimiotaxia só tiveram um avanço considerável há duas décadas. Foi então que o mecanismo de transdução de sinais das células começou a ser revelado [14].

Além do processo de transdução e de transmissão de informações do ambiente externo, os receptores também processam estas informações. Neste processo de transdução devemos citar que as bactérias são altamente sensíveis às variações na concentração, mas são, praticamente, insensíveis a estímulos constantes. Tal comportamento é conseguido por uma combinação de uma resposta rápida e altamente sensível a alterações nas concentrações destes estímulos seguido por uma adaptação lenta e precisa.

Neste processo de detecção da concentração dos estímulos, o tamanho da bactéria tem influência em seu comportamento, pois devido a ele, a bactéria pode não ter capacidade de detectar com eficácia o gradiente do estímulo, portanto, a avaliação do ambiente é feita através de um movimento constante (para frente ou dando guinadas). Uma estratégia diferente é usada na quimiotaxia eucariótica que, ao contrário do primeiro, devido o seu tamanho, tem a possibilidade de detectar o gradiente e se locomover através dos pseudópodes, presente em algumas células eucariontes (Figura 5). Pseudópodes são heterogêneos e constantemente feitos, alterados e reabsorvidos. Qualquer célula eucarionte pode ter nenhum, um ou muitos, sendo seu número e o 


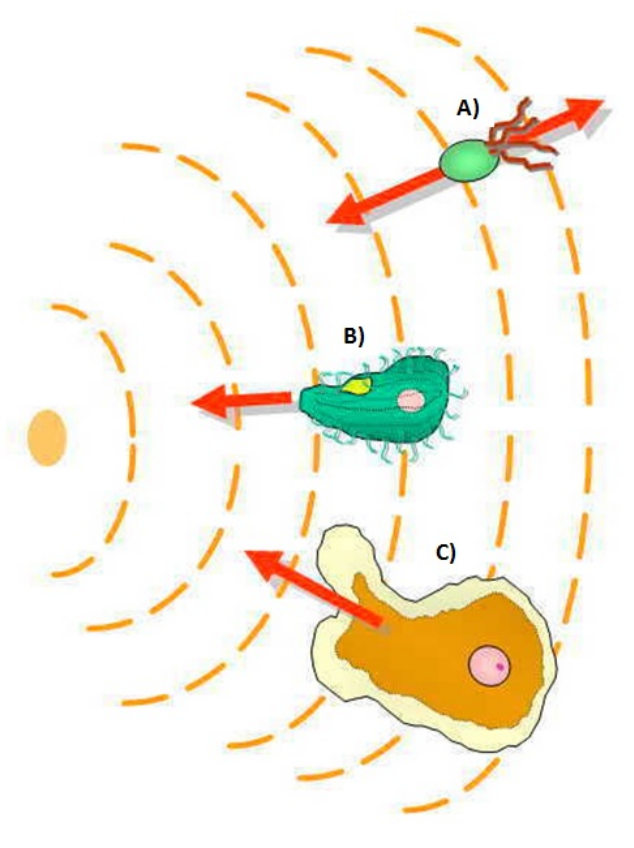

Figura 5 - Representação do movimento: A) das bactérias; B) e C) das células eucariontes [11]

comportamento diretamente ligados aos estímulos presente no ambiente da célula [15]. No entanto, em ambos os casos, nas bactérias e nas células eucarioticas a presença do gradiente químico ainda é essencial para desenvolvimento do processo da quimiotaxia.

\subsection{Mecanismo da quimiotaxia bacteriana}

A quimiotaxia da E. Coli é uma forma de se movimentar no ambiente, seja em busca de nutriente ou fugindo de repelentes. A estratégia mais usada para que seja feito este deslocamento é o movimento impulsionado pela rotação de seus flagelos, organelas externos à célula que servem como hélices. Estes flagelos exercem uma força que empurra a bactéria, fazendo elas se deslocarem de forma relativamente rápida, até 20 a $30 \mu \mathrm{m} / \mathrm{s}$ [12].

Outro ponto importante é que cada espécie de bactéria tem alguma característica diferente com relação ao tipo de movimento que elas podem executar durante seu processo de locomoção. Esse tipo de movimento está diretamente ligado à forma como são distribuídos os flagelos ao longo de seu corpo celular e também ao tipo de espécie da bactéria. Algumas espécies têm a característica de se movimentar apenas para frente e para trás sendo que a sua orientação seguem um movimento Browniano, como exemplo dessas espécies podemos citar: Pseudomonas spp., Spirillum spp., Chromatium 


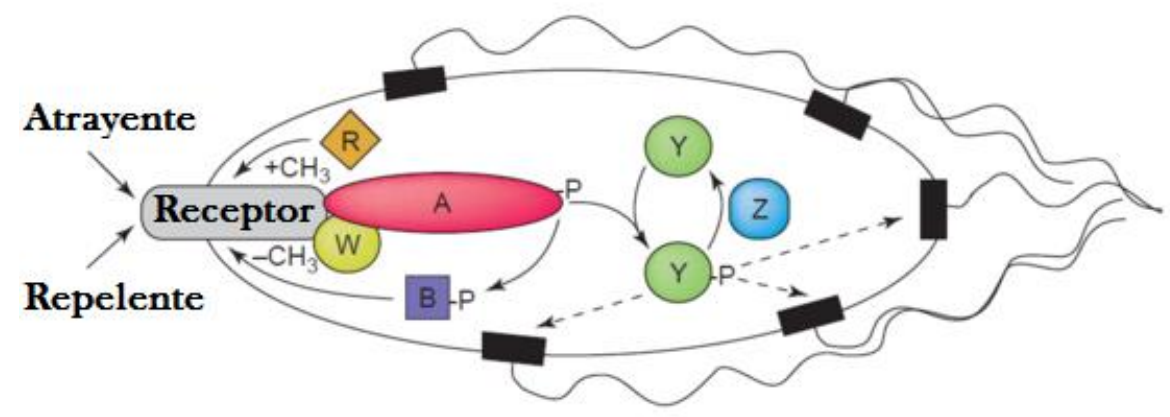

Figura 6 - Ilustração das vias de sinalização da Escherichia Coli, demostrando as comunicações feitas entre CheA, CheW, CheY, CheR, CheB e CheZ; suas devidas fosforizações em CheA e CheY e desfosforizações devido a influência dos CheB e CheZ (SOURJIK, 2004).

spp. e Halobacteria. Em outras espécies os movimentos são apenas em linha reta, como por exemplo: Escherichia coli, Salmonella typhimurium, Sinorhizobium meliloti, sphaeroides Rhodobacter e Agrobacterium. No entanto, nada impede que existam bactérias que tenha as duas características de tipo de deslocamento, exemplo desse caso, podemos citar as células de Vibrio alginolyticus [12]. A Tabela 1 mostra detalhadamente cada bactéria e a contribuição que os flagelos e suas distribuições pelo corpo celular têm em relação à sua mobilidade.

Mitchell (2002) analisa quatro estratégias de movimento para a quimiotaxia que pode estar presente em diversos tipos de bactérias: Corrida (natação) e guinada (giro); corrida e arco; corrida e parada e corrida e reversa. Das quatro estratégias identificadas a mais conhecida e mais simples de se traduzir em regras simples é a de "corrida e guinada" [16]. Neste trabalho o movimento estudado será o movimento caraterístico da Escherichia Coli que é o de "corrida e guinada".

A bactéria detecta o gradiente químico do entorno usando os receptores e faz uma comparação temporal contínua dos gradientes encontrados e a cada instante, dependendo das condições externas, ela toma a decisão de continuar a "corrida", ou "girar" (dar guinadas) os flagelos até detectar a presença de outro gradiente.

Como mostrado na Figura 6, além do receptor podemos perceber a existência de seis proteínas (CheA, CheB, CheR, CheW, CheY, CheZ) que são as principais responsáveis pelo processo da quimiotaxia no interior da Bactéria. A enzima chave é a histidina quinase CheA que através da proteína CheW é ligada aos receptores (essa descrição será mais detalhada na seção 1.7). 


\section{Tabela 1 - Variedade da Motilidade nas Bactérias [12]}

\begin{tabular}{llll}
\hline $\begin{array}{l}\text { DISTRIBUIÇÃO DOS } \\
\text { FLAGELOS }\end{array}$ & APARÊNCIA & $\begin{array}{l}\text { ESPÉCIE PARA EXEM- } \\
\text { PLO }\end{array}$ & DESCRIÇÃO DE MOTILIDADE \\
\hline $\begin{array}{l}\text { Um único flagelo (ou } \\
\text { quase) em um dos polos } \\
\text { celulares. }\end{array}$ & & $\begin{array}{l}\text { Pseudomonas spp } \\
\text { Dependendo do sentido de rotação do }\end{array}$ & $\begin{array}{l}\text { flagelo ele pode empurrar ou puxar a cé- } \\
\text { lula, em um movimento de vai e volta. }\end{array}$ \\
\hline
\end{tabular}

Um único flagelo, aparentemente entre os polos.
O flagelo pode girar no sentindo antihorário ou pausar. Consequentemente a célula nada em uma linha reta e, ocasionalmente, para e se reorienta.
Conjunto de flagelos em um dos polos.

\section{Orna Rhodobacter sphaeroids}

Conjunto de Flagelos
em cada um dos dois
polos.

Chromatium okenii

Dependendo do sentido de rotação o conjunto de flagelos pode empurrar ou puxar a célula, em um movimento de vai e volta.
Conjunto de flagelos em cada polo da Spirillum spp.

\section{Spirillum Volutans}

O movimento para frente e para trás é realizado da mesma maneira. Seu corpo da célula helicoidal gira em reação da rotação dos Flagelos, produzindo um impulso para a motilidade.
5 a 10 Flagelos distribuídos aleatoriamente em torno da célula.

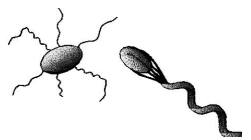

Escherichia Coli, Salmonella typhimurium, Bacillus subtilis.
Na maioria das vezes os Flagelos giram em um sentido anti-horário e as células nadam em uma linha reta, intermitentemente, os Flagelos giram no sentido horário, fazendo com que a célula dê guinadas aleatórias.
5 a 10 Flagelos distribuídos aleatoriamente em torno da célula.
Na maioria das vezes os Flagelos giram em um sentido anti-horário e as céluSinorhizobium melimoti las nadam em uma linha reta, ocasionalmente, mudanças na velocidade de rotação dos flagelos causam uma transformação.
Dois Flagelos em um polo e 2 a 4 Flagelos laterais.

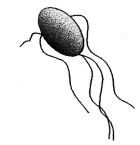

Agrobacterium tumefaciens
Flagelos giram em sentido horário ou ficam parados, consequentemente, as células nadam em linha reta ao invés de dar voltas.
Flagelos excessivos em torno da célula.
E. Coli, S. typhimurium,

Serratia marcescens, Pro- Mobilidade superficial em uma colônia. teus mirabolis

\begin{abstract}
Um Flagelo em uma Extremidade e um ou mais sub-Flagelos subterminal em cada extremidade, todos os Flagelos são constituídos no espaço periplasmático.
\end{abstract}

Os Flagelos Peri plasmáticos fazem a célula dobrar ou girar, quando o feixe flagelar, situados nos polos da célula, giram em sentidos opostos (um puxa e um empurra) a célula nada em linha reta, quando os dois feixes nadam no mesmo sentido a celular flexiona. 

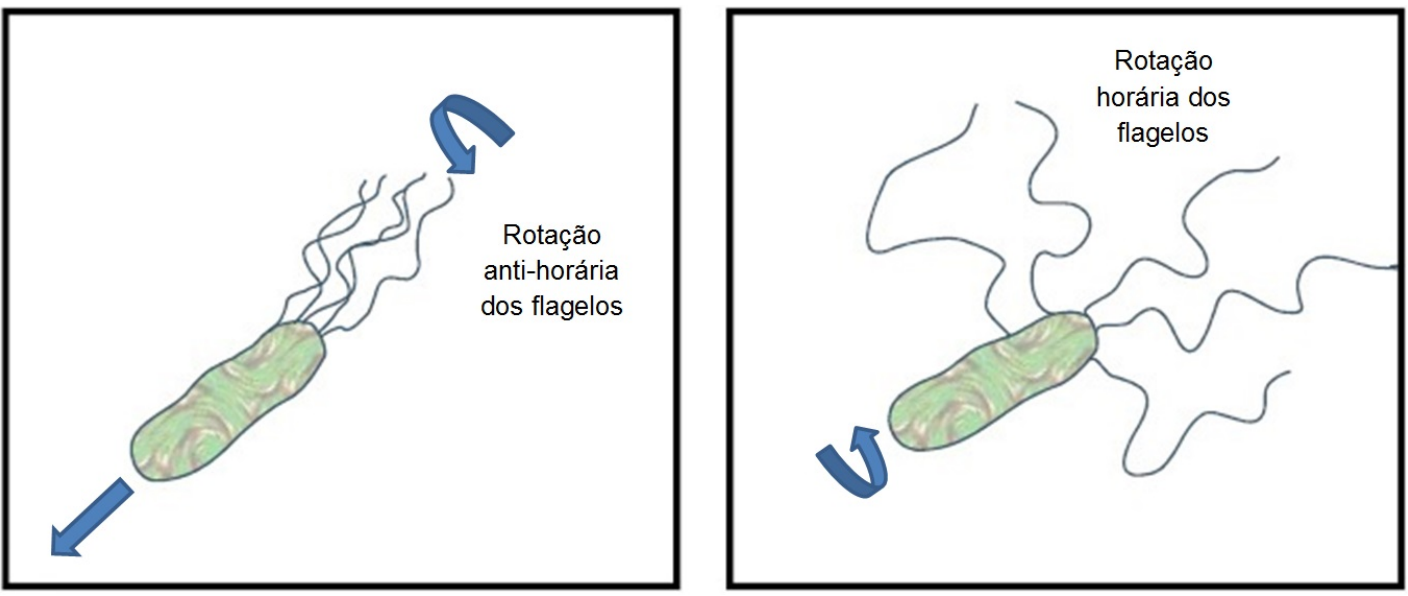

Figura 7 - Movimento de natação e giro das bactérias ([16], com adaptações do autor).

Os Flagelos das bactérias tem formato helicoidal, podendo girar de 270 a 600 rotações por segundo [17]. Como consequência, quando todos eles giram no mesmo sentido (rotação horária), atuam como propulsores, movimentando a bactéria suavemente para frente num movimento quase retilíneo [16]. No caso das E. Coli, os flagelos giram no sentido anti-horário. O formato helicoidal faz com que os flagelos quando girados na direção contrária ao da natação (horário) se desestabilizem e impulsionem a célula em diversas direções ao mesmo tempo, girando aleatoriamente [16]. A Figura 7 representa a natação e o giro. A combinação desses dois movimentos é responsável por fazer a bactéria se movimentar em seu ambiente.

Guzman (2009) detalhou o comportamento da bactéria de acordo com as substâncias e o gradiente encontradas no ambiente. Para ela, se o ambiente for neutro, a bactéria alterna os movimentos de natação e giro, descrevendo um movimento aleatório (random walk) e continua explorando. Caso a bactéria encontre um atraente químico, mas sem gradiente, a velocidade média da natação aumenta e a duração dos giros diminui instantaneamente e depois volta lentamente ao normal. Se a bactéria encontrar um gradiente, seja de quimioatraente ou quimiorepelente, ela alterna os movimentos de natação e giro. Diminuindo o numero de giro se for um atraente e aumentando se for um repelente. Figura 8 representa esse movimento.

\subsection{Descrição da rota metabólica da quimiotaxia}

A quimiotaxia é um processo que envolve diversos fatores, como a existência de várias funções desempenhadas pelos elementos internos e externos. Assim, não são 


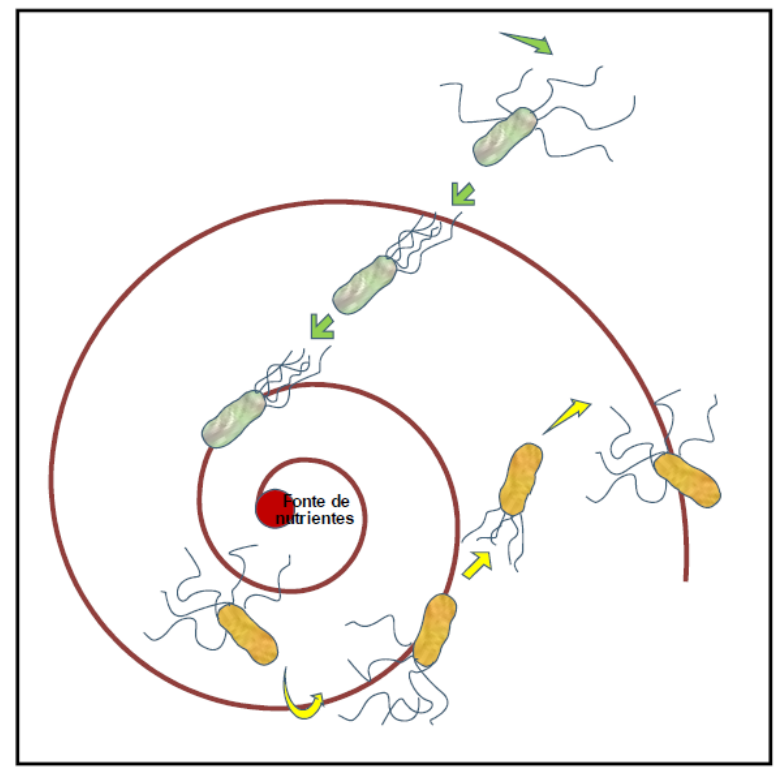

Figura 8 - Movimento quimiotático das bactérias [16].

apenas fatores externos, como, os receptores e as concentrações de ligante/estímulos que executam o papel principal na quimiotaxia. Além da parte externa do receptor, existe a parte interna onde são situados os sítios metílicos. Na bactéria E. Coli cada receptor possui quatro sítios metílicos (Figura 9), nos quais podem ser adicionados ou retirados grupos metílicos fazendo com que os receptores se tornem ativo, ou inativo. Se o receptor ganha grupos metíticos ele se torna mais ativo, se perde, ele fica mais inativo.

Ainda no interior da bactéria, existem proteínas que dão o real efeito para todos esses elementos externos, ou seja, recebem as informações externas e as traduzem no interior da bactéria. O ambiente interno é responsável pela parte de transdução do sinal recebido pelos receptores, fazendo com que após a transmissão interna dessas informações, as bactérias decidam que tipo de direção devem tomar durante seu percurso. Desta forma, a descrição das funções das proteínas internas (CheA, CheW, CheR, CheB, CheY e CheZ) é de fundamental importância para entender o processo da quimiotaxia. A Figura 10 mostra um esquema simplificado das interações entre receptores, proteínas e motor-flagelar. Eisenbach (2004) e outros autores definem as funções de cada uma dessas proteínas em seu trabalho da seguinte forma:

CheA - Histidina quinase que pertence à super-família de sistemas reguladores com dois componentes, um sensor e um regulador de respostas. Um domínio de acoplamento promove a ligação de CheA aos receptores, por meio de CheW [13]. 


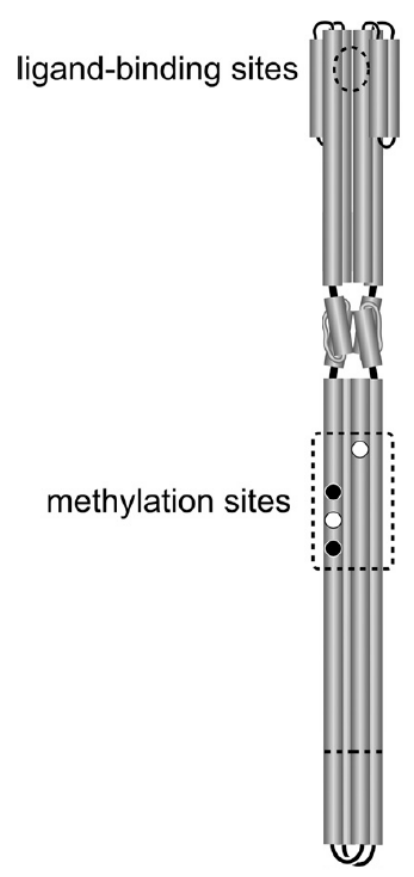

Figura 9 - Sítios metílicos dos receptores da E. Coli: sitios ocupados (círculo escuro), sítios vagos (círculo claro) [9].

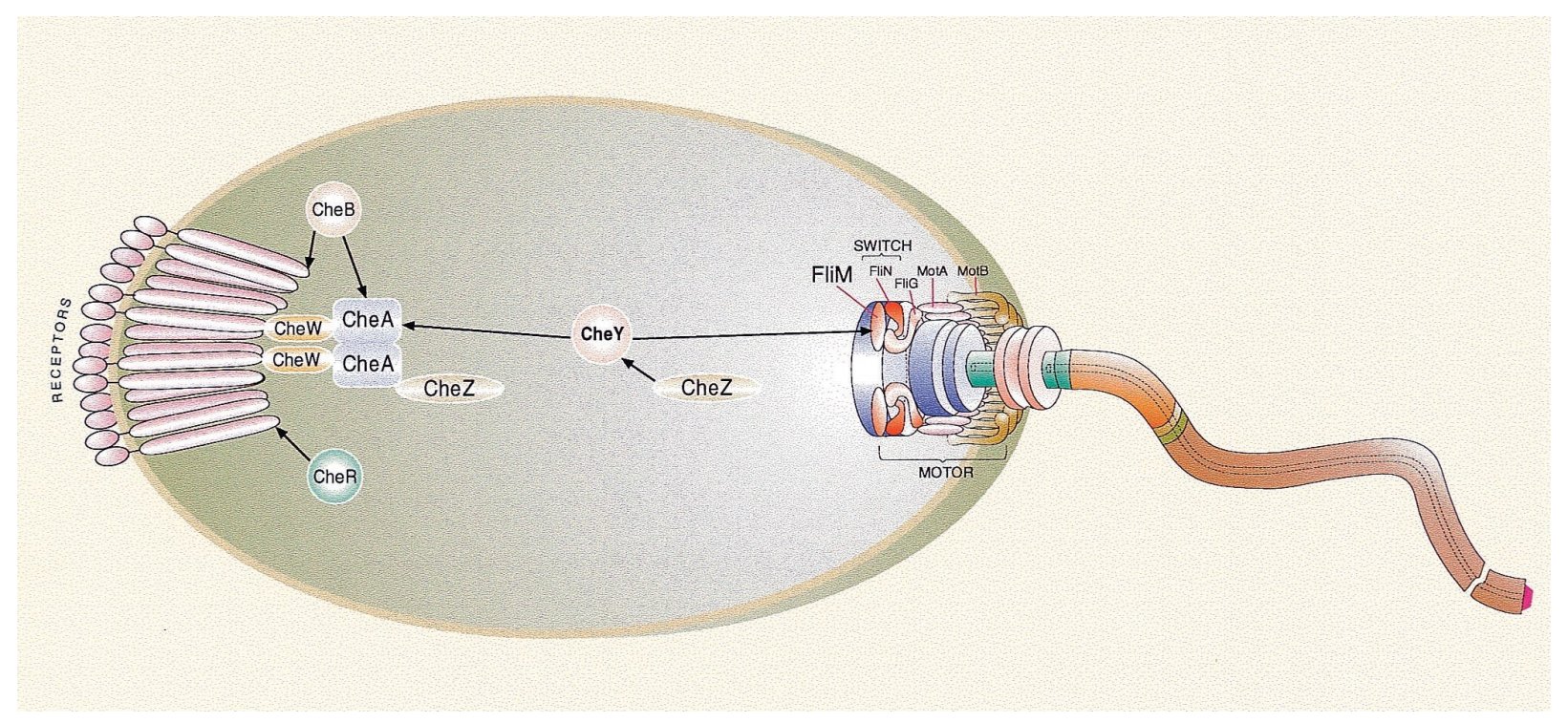

Figura 10 - Esquema simplificado da interação entres os receptores, as proteínas (CheA, CheW, CheB, CheR, CheY e CheZ) e o motor flagelar (FliM) durante o processo de transdução de sinal quimiotático na Bactéria [9]. 
Assim formam um complexo ternário, no qual tornam ativos os receptores. CheA tem como principal função se submeter a uma auto-fosforilação. O grupo fosfato pode ser transferido rapidamente para CheY, que influencia o sentido de rotação do motor-flagelar (horário e anti-horário), ou pode ser transferido para $\mathrm{CheB}$, onde terá um papel importante na adaptação da bactéria [7]. O processo de adaptação será estudado na seção 1.8 .

CheB - Regulador de resposta que juntamente com o CheR controlam o nível de metilização dos receptores. Tem como principal função a desmetilização (retirada de grupos metílicos dos receptores). O resultado desta desmetilização é a inibição da autofosforilação de CheA [9]. Ainda para Bren e Eisenbach (2000) CheB possui dois alvos de interação, os receptores e CheA. Sendo que na última interação CheA fosforiza CheB e o libera para interação com os receptores.

CheR - É uma enzima relativamente lenta e tem como principal função metilizar os receptores. É dividido em dois domínios: um responsável pela identificação do substrato e o outro pela transferência de grupos metílicos para o receptor [7].

CheW - Conhecida como uma proteína adaptadora [18]. Tem como função principal estabelecer a comunicação entre CheA e os receptores, apenas em alguns casos CheA pode ser acoplado aos receptores diretamente.Tem um papel importante na comunicação entre os receptores. CheW também pode estar envolvido, de certa forma, na autofosforilação de CheA e na fosfotranferência para CheY [7].

CheY - Proteína relativamente pequena que tem como principal função a ponte entre o complexo dos receptores e o complexo de ativação do motor-flagelar (Figura 10), fazendo com que ocorra a mudança na direção de rotação dos flagelos, horário e anti-horário, a partir da informação que é dada pelos receptores. Para desempenhar esse papel é necessário que CheY sofra uma fosforilação relativamente rápida de CheA.

CheZ - Considerado uma proteína única, está presente apenas em bactérias entéricas (bactéria situadas no intestino de humanos e animais), tais como E. Coli e Salmonellas. Tem como função, melhorar a desfosforilação de CheY, fazendo com uma grande especificidade, tendo em vista que ela não consegue desfosforilar CheB. Para se fosforilizar, CheZ tem forte dependência de CheY-P (CheY fosforilado). 
Dessa forma, sob condições não estipuladas, quando o nível celular de CheY-P é baixo a influência de CheZ na desfosforilação de CheY é insignificante. No estado estacionário, ou perto dele, CheY é fosforizada por CheA no mesmo ritmo que CheZ desfosforiza CheY [13].

Assim, o funcionamento coletivo da rota metabólica, a partir dos receptores e das proteínas, pode ser descrito como um movimento das bactérias em um ambiente uniforme, onde esse movimento inicial é caracterizado por uma natação reta com leves guinadas que servem para a reorientar a bactéria. Nessa situação, o estado de uma fração dos receptores é ativo fazendo com que CheA se auto-fosforize. Esses grupos fosfatos adquiridos por CheA são transferidos para CheY fazendo com que ele vire CheY-P e para CheB tornando-os CheB-P. A presença, ou não de CheY-P no motor flagelar (FLiM) regula seu movimento (horário e anti-horário). Com o acúmulo de CheY-P no motor flagelar a bactéria realiza guinadas aleatórias com grande frequência, movimento horário. A regulação do nível de CheY-P é feita por CheZ, que é responsável pela retirada do grupo fosfato de CheY. Na presença de um gradiente de concentração de ligante o receptor conecta-se a um estímulo tornando-o inativo, com isso ocorre uma diminuição na auto-fosforilação de CheA e, consequentemente, CheY-P. Sem a produção constante de CheY-P, sua concentração diminui devido à presença de CheZ, com isso o motor flagelar gira no sentido anti-horário, fazendo com que a bactéria descreva um movimento reto e mais prolongado.

Assim, com um nível alto de concentração de ligante/estímulo, a forforilação de CheA e a fosforilação de CheB e CheY será pequena, fazendo com que a bactéria diminua o número de guinadas e nade sem problemas. Sem a presença de CheB-P para desmetilar e devido a baixa atividade dos receptores, CheR começa adicionar grupos metílicos nos receptores, tornando-os ativos novamente. Com os receptores ativos, ocorre novamente a auto fosforilação de CheA e, consequentemente, de CheB-P em menor taxa do que CheR, o que leva a bactéria a ter a mesma atividade do início do processo.

Portanto, a presença de CheR e CheB, no mecanismo da quimiotaxia, está diretamente ligada a atividade do receptor, pois se a $E$. Coli estiver em um ambiente onde existem muitos atraentes químicos ela também manterá muitos receptores inativos. Quando isso ocorre, a proteína CheR entra em ação adicionando grupos metílicos aos 
receptores tornando-os ativo novamente, o que faz a bactéria voltar a dar guinadas aleatórias. No entanto, se a E. Coli entrar em um ambiente com baixa concentração de nutrientes, aumentando a atividade dos receptores, CheB começa a retirar grupos metílicos fazendo com que a bactéria atinja o estado inativo novamente. Desta maneira, a E. Coli busca sempre se adaptar ao meio em que vive e com esse comportamento sempre busca o lugar com maior concentração de nutrientes.

A determinação da estrutura dos quimiorreceptores e de todas as proteínas Che ofereceu uma base para a compreensão de como está montado o complexo de sinalização existente nos receptores [18]. Portanto, a interação entre receptores, proteínas e motorflagelar é que são responsáveis pelos movimentos e pelo comportamento da bactéria, seja para buscar nutrientes ou para fugir dos repelentes.

\subsection{Robustez e adaptação}

O processo de adaptação das bactérias, quando submetidas a certa concentração de estímulos, é um dos assuntos mais estudados na quimiotaxia das bactérias. A adaptação consiste basicamente no retorno ao mesmo nível de atividade após uma mudança na frequência de guinadas da bactéria provocada pela alteração na concentração do estímulo [19]. Dessa forma, a bactéria adapta-se ao novo ambiente. Para Eisenbach (2004) a adaptação é um processo de recuperação de um comportamento quando o estímulo ainda está presente, sendo essencial para qualquer sistema comportamental, pois permite a detecção de pequenas mudanças no nível do estímulo. Na Quimiotaxia bacteriana, a adaptação permite responder a novos estímulos, quando estão na presença de níveis constantes de atraentes-químicos, ou repelentes-químicos.

Este processo de adaptação depende das proteínas CheR e CheB, respectivamente responsáveis por adicionar e subtrair grupos metílicos dos receptores celulares. A adição, ou subtração deve ser feita na quantidade certa, de modo que a bactéria consiga direcionar seus movimentos aos locais com maiores concentrações de nutrientes [20]. Conforme mencionado na seção 1.7, a adição de grupos metílicos no receptor pela proteína CheR faz com que ele aumente sua atividade, compensando a redução de atividade provocada pela conexão de ligantes no receptor, fazendo com que a bactéria volte a dar guinadas aleatórias a maior frequência. Com a diminuição do número de grupos metílicos ligados ao receptor, ele tende a permanecer no estado inativo, o que 


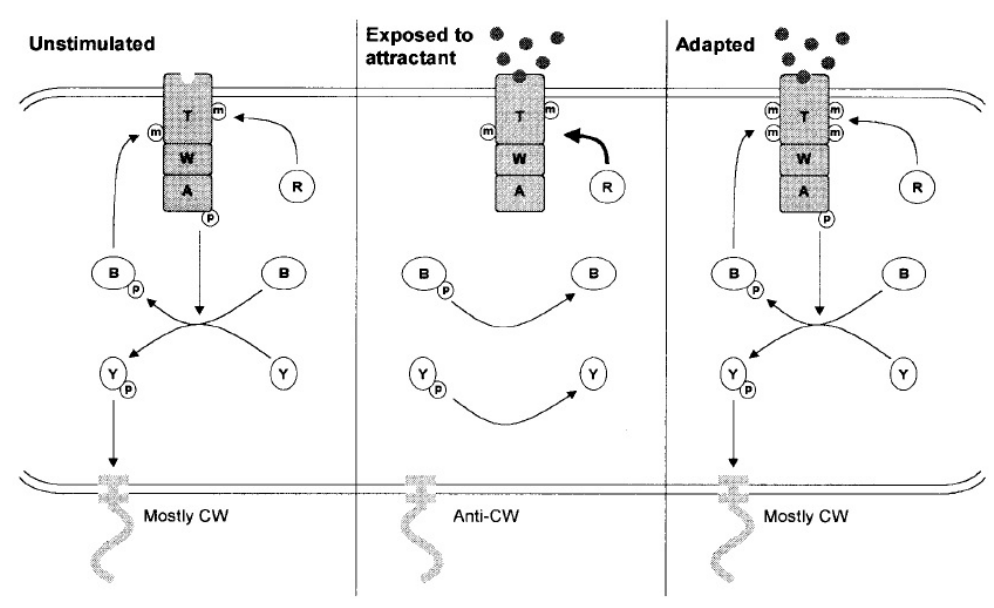

Figura 11 - Demonstração do Esquema interno da bactéria, mostrando a adição e subtração dos grupos metílicos: a) receptor esta ativo e na ausência de nutrientes conectados, CheR adiciona e CheB retira os grupos metílicos em quantidades aproximadamente iguais; b) na presença de uma grande concentração de nutrientes, CheR faz a metilização sem a utilização de cheB; c) após adaptado Che-B volta a retirar grupos metílicos e o número de grupos metílicos se estabiliza num nível mais alto [20]

faz com que a bactéria permaneça no local onde os nutrientes então mais concentrados. Portanto, CheR e CheB funcionam como reguladores da atividade da bactéria. A Figura 11 exibe um esquema da ação e mostra esse mecanismo com mais detalhes.

Para Lan, Schulmeister, Sourjik e Tu (2011) a adaptação sensorial da E. Coli é realizado pela metilização e desmetilização dos receptores, medidas por duas enzimas citoplasmáticas: CheR e CheB que adicionam e removem grupos metílicos.

Com essa característica da adaptação perfeita das bactérias, é de se imaginar que a adaptação possa depender criticamente da quantidade de moléculas das proteínas envolvidas na quimiotaxia. No entanto, estudos mostram que a adaptação perfeita é uma propriedade robusta da quimiotaxia, ou seja, a precisão da adaptação das bactérias ao meio que esta é inserida independe, em grande parte, da quantidade da concentração das proteínas da via metabólica [19]. Barkai e Leibler e, em seguida, Alon e outros comprovaram essa robustez e demostraram experimentalmente que a adaptação da bactéria é precisa e independe do nível exato das proteínas envolvidas na adaptação. A explicação para esta questão foi dada por Alon (1999) da seguinte maneira: por envolver propriedades críticas a função deve ser robusta, de forma a resistir às variações naturais do ambiente. A adaptação perfeita é uma função crítica para a quimiotaxia, enquanto a queda de frequência do estado estacionário e o tempo de adaptação podem ser inexatos, 


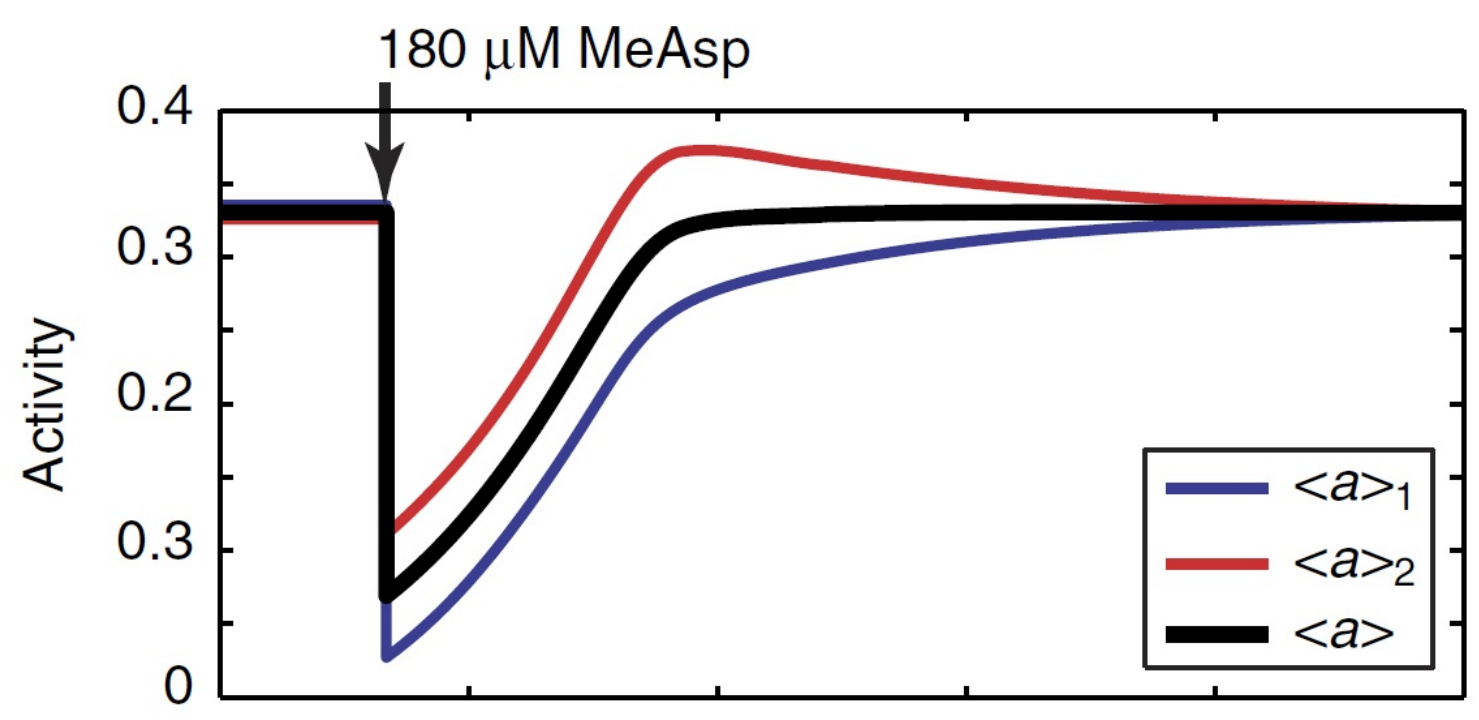

Figura 12 - Comportamento da atividade em meio a uma concentração de estímulo. Adaptação perfeita, linha preta [21].

sem que isso provoque um efeito grave sobre a capacidade de resposta quimiotática [7]. A figura 12 mostra como é o comportamento da atividade quando submetida a uma concentração de estímulo, com sua queda e adaptação.

Como exemplo, do processo de adaptação, podemos considerar o sistema sensitivo nervoso, onde, com a aplicação de estímulos contínuos o sistema reage com o aumento da frequência de impulsos, em resposta a variação do estímulo, diminuído e se adaptando progressivamente quando o estímulo se torna constante [22]. 


\section{Receptores}

\subsection{Cooperatividade}

A capacidade de nadar em direção aos nutrientes e de se afastar dos repelentes tem início com os receptores, pois são eles que captam estes sinais. Para alcançar este objetivo, algumas células são equipadas com milhares de receptores formando grandes matrizes em um, ou ambos os lados da bactéria [23]. Ainda segundo Endres (2007), algumas propriedades da quimiotaxia, como por exemplo, integração do sinal por vários tipos de quimiorreceptores, adaptação perfeita, que como já vimos é de fundamental importância para o desenvolvimento da célula, e a alta sensibilidade a mudanças de concentração dos ligantes, são iniciadas nessa rede complexa de receptores.

No estudo da quimiotaxia foram descobertos três grupos mutantes de identificação de receptores, que têm como principal diferença a capacidade de se ligarem com tipos de estímulos diferentes. Para Eisenbach (2004) esses três grupos são: mutantes que são "não quimiotáticos" apenas para alguns estímulos específicos; mutantes que são "não quimiotáticos" para vários estímulos (mas não todos) e mutantes que são "não quimiotáticos" para todos os estímulos. A E. Coli está enquadrada no segundo e terceiro grupo, possuindo receptores que se ligam a apenas alguns estímulos e receptores que não se ligam com nenhum estímulo. Na E. Coli os receptores se espalham por todo o corpo da bactéria, concentrando-se na extremidade oposta aos flagelos, sendo uma parte externa e outra interna à célula. Na parte externa eles são responsáveis pela ligação com os ligantes e na parte interna inicializam o processo de transdução das informações, influenciando todas as proteínas internas (CheA, CheB, CheR, CheY e CheZ). Na parte interna os receptores também sofrem influência das metilizações/desmetilizações e ajudam na fosforilação necessária ao processo da transdução do sinal.

Conforme seção 1.5, existem cinco tipos de quimiorreceptores na bactéria E.Coli que detectam uma variedade de estímulos os Tsr, Tar, Tap, Trg e Aer, sendo os mais abundantes os tipos Tsr e o Tar [24]. Estes receptores cumprem pelo menos três papéis na quimiotaxia bacteriana. Em seu trabalho, Eisenbach (2004) cita os três papéis como: ligar ao ligante, ou, ao menos, perceber as mudanças na temperatura; fazer a transdu- 
ção do sinal quimiotático através da membrana citoplasmática e ter participação no processo de adaptação, por meio da metilização/desmetilização. A principal função dos aglomerados de receptores é a de regular a atividade da proteína CheA, a qual, por sua vez, afeta o nível de fosforilação da proteína CheY que controla o motor-flagelar (FLim) , responsáveis pela movimentação da célula (figura 10), por meio de uma resposta de CheY.

Outro objeto de estudos dos receptores é a interação entre eles em uma mesma célula. Estudos mostram que a interação dos receptores é responsável pelo aumento da sensibilidade de diferentes vias de sinalização e acredita-se que a cooperatividade causada pela concentração dos receptores contribui para o elevado ganho na transdução do sinal na bactéria Escherichia Coli [25]. A vantagem de se estudar o sistema sensorial das bactérias é descrever como, em um nível molecular, o sinal é recebido, transduzido e regulado. No caso da E. Coli esse estudo já é desenvolvido [24].

A dedicação de muitos trabalhos na área de interação entre os receptores fez com que diversos modelos fossem propostos para explicá-lo, como exemplo, podemos citar o modelo de Ising e o MWC (Monod, Wyman e Changeux), ou modelo de "tudo ou nada". Este último se assemelha com o modelo de Ising, mas tem como limitação a interação a apenas grupos com o mesmo estado de atividade, fazendo com que a força de interação, nestes grupos, seja levada para o infinito e entre receptores de subgrupos diferentes a força de interação seja nula, como mostra a figura 13 [1]. No entanto, no modelo do tipo Ising é difícil determinar as propriedades do receptor individualmente e as propriedades dos aglomerados a partir dos dados obtidos como resposta, já o modelo de MWC é mais simples e mais intuitivo para descrever a cooperatividade dos receptores [24].

O modelo de MWC foi usado por Mello e Tu (2007) para descrever a sensibilidade e adaptação dos receptores. Neste trabalho o modelo de MWC foi generalizado para que pudesse descrever a quinase de um conjunto misto de quimiorreceptores, com o intuito de estudar a integração do sinal e explicar os dados das respostas para diferentes tipos de estímulos. Como resultado, Mello e Tu comprovaram que a maior sensibilidade é uma consequência direta da cooperatividade dos receptores e que a adaptação sincroniza as respostas dos complexos de receptores dentro de uma única célula, tendo influência na resposta média do sistema. A cooperatividade entre os receptores como 

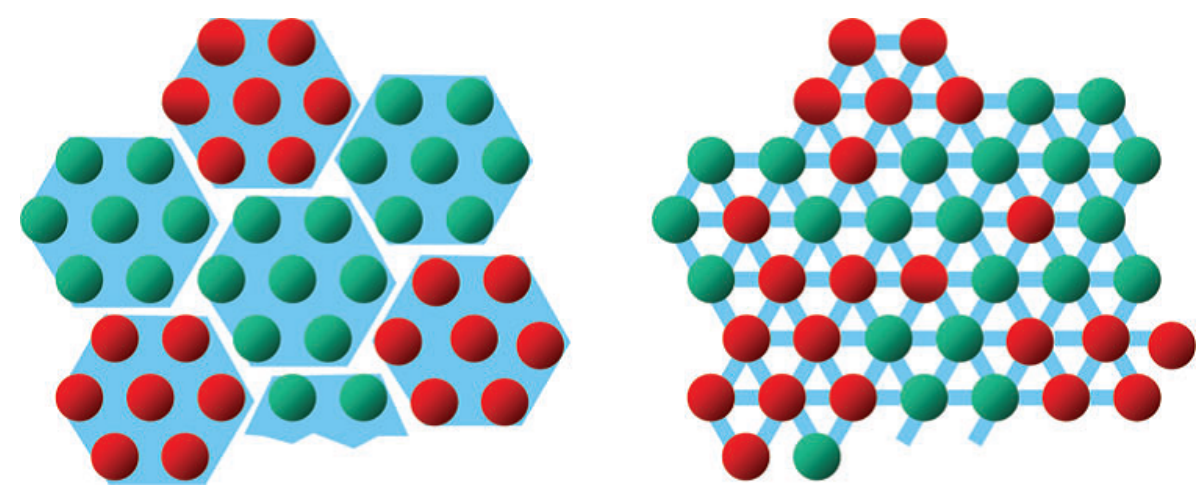

Figura 13 - Diferença entre os modelos MWC e Ising. No modelo MWC a interação é apenas entre os receptores do mesmo grupo. No modelo de ising a interação é dada com os vizinhos mais próximos, não existe grupo [1].

mecanismo para um aumento do ganho do sistema foi sugerido pela primeira vez por Bray, Levin e Morton Firth [26], mais tarde Shi e Duke [27], propuseram o estudo baseado no modelo de Ising, considerando que receptores idênticos interagiam com seus vizinhos mais próximos [28]. Mesmo com esses modelos bem fundamentados, propostos anteriormente, algumas informações ainda foram suprimidas, como por exemplo, os estado de metilização de cada receptor envolvido no modelo e a inclusão das interações entre receptores heterogêneos de diferentes tipos [28]. Atualmente o modelo de Ising é o que mais bem se encaixa nos padrões encontrados nos experimentos, pois não restringe as interações entre os receptores, onde cada receptor pode ser de um tipo diferente, como por exemplo de Tar (serina) ou Tsr (aspartato) [21].

Estudos recentes mostram que a amplificação do sinal pode depender não somente dos receptores, mas também do estado de metilização/desmetilização promovido respectivamente por CheR e CheB, tal afirmação se dá com base nos estudos propostos por Sourjik e Berg, empregando FRET (Fluorecence Resonance Energy Transfer) instrumento utilizado para monitorar as interações protéicas em tempo real [29]. Para Eisenbach (2004) parece razoável que existam duas etapas de amplificação, uma ao nível do complexo de receptores e outra ao nível do motor flagelar.

\subsection{Comunicação e amplificação do sinal}

Uma vez que os tipos de movimentos estão diretamente ligados aos receptores, é a partir deles que o processo de quimiotaxia ocorre. Devemos saber como esses receptores se comportam na presença de um gradiente de nutrientes e como ocorre a 
comunicação entre eles. Mello, Shaw e Tu (2004) mostraram que as interações entre os receptores devem ser vista como um modelo de Ising, onde sabemos que a interação entre vizinhos diretos e indiretos podem ter influência em um receptor escolhido.

A ideia proposta em Duke e Bray (1999) é simplificar os estudos dos receptores descrevendo-os com apenas duas formações discretas: uma ativa e outra inativa. Essa ideia foi bem aceita nos estudos das interações entre os receptores, pois pode comparar os receptores com os estados dos spins, sendo o receptor ativo equivalente a um spin-up e um receptor inativo equivalente a um spin-down. Dessa forma, podemos fazer o estudo de acordo o modelo de ising, onde a influência do vizinho mais próximo afeta o estado do seu vizinho imediato. Considerando que em uma célula existem milhares de receptores e que eles podem estar agrupados uns com os outros é intuitivo perceber que um sinal, seja de um atraente ou de um repelente, será muito mais forte, amplificando a resposta global da bactéria.

No entanto, a simples ideia de considerar os receptores apenas como ativo e inativo, pode não ser a maneira mais real de se verificar os estados da bactéria como um todo, tendo em vista que a situação de atividade ou inatividade pode ser alterada tanto pela conexão do receptor a um atraente como pela metilização produzida pela própria célula no receptor. Assim, para podermos considerar esse processo devemos levar em conta quatro estados no geral: ativo e inativo representados por $a=0,1$; com atrator conectado (com ligante) e sem atrator conectado (sem ligante) representado por $l=0,1$, sendo caracterizado então por um par de variáveis binárias $(a, l)$. A probabilidade para os quatro estados pode ser dada por $p_{a l}$ [30] e pode ser obtido das equações:

$$
\frac{p_{01}}{p_{00}}=\frac{[L]}{k_{i}}, \quad \frac{p_{11}}{p_{10}}=\frac{[L]}{k_{a}}, \quad \frac{p_{10}}{p_{00}}=e^{-f_{m}(m)}
$$

Onde $[L]$ representa a concentração do ligante, $k_{i}$ e $k_{a}$ são constantes químicas de dissociação para o ligante nos estados de ativo e inativo, e $f_{m}(m)$ é a diferença de energia livre entre ativo e inativo na ausência de ligante. Essa diferença depende do estado de metilização do receptor, representado pela variável $m$.

Considerando a condição de normalização $\sum_{a, l} p_{a, l}=1$ e utilizando as possibilidades possíveis entre $a$ e $l$, dadas pela equação 2.1 , temos que a atividade média do receptor, considerando as probabilidades de cada estado, seja ativo com ligante e ativo 
sem ligante, pode ser encontrada da seguinte maneira:

$$
\begin{gathered}
\langle a\rangle=\sum_{a=0}^{1} \sum_{l=0}^{1} a p_{a l}=p_{10}+p_{11} \\
\langle a\rangle=p_{10}+\frac{[L]}{k_{a}} p_{10} \\
\langle a\rangle=p_{10}\left(1+\frac{[L]}{k_{a}}\right)
\end{gathered}
$$

Considerando a condição de normalização e fazendo as substituições de acordo com as equações 2.1 teremos:

$$
\begin{gathered}
\sum_{a l} p_{a l}=p_{00}+p_{01}+p_{10}+p_{11}=1 \\
p_{00}+\frac{[L]}{k_{i}} p_{00}+p_{10}+\frac{[L]}{k_{a}} p_{10}=1 \\
p_{00}\left(1+\frac{[L]}{k_{i}}\right)+p_{10}\left(1+\frac{[L]}{k_{a}}\right)=1 \\
\frac{p_{10}}{e^{-f_{m}(m)}}\left(1+\frac{[L]}{k_{i}}\right)+p_{10}\left(1+\frac{[L]}{k_{a}}\right)=1 \\
\left.e^{+f_{m}(m)}\left(1+\frac{[L]}{k_{i}}\right)+\left(1+\frac{[L]}{k_{a}}\right)\right] p_{10}=1 \\
p_{10}=\frac{1}{e^{+f_{m}(m)}\left(1+\frac{[L]}{k_{i}}\right)+\left(1+\frac{[L]}{k_{a}}\right)}
\end{gathered}
$$

Substituindo a expressão anterior na equação 2.4 chegamos à:

$$
\langle a\rangle=\frac{1}{1+e^{f_{m}(m)} \frac{1+\frac{[L]}{k_{i}}}{1+\frac{[L]}{k_{a}}}}
$$

Que analogamente pode ser comparada com a atividade média de um dipolo magnético, onde considerando a atividade com apenas dois estados, o estado com energia $E_{1}$ e o estado com energia $E_{0}$,

Considerando:

$$
a=0 \rightarrow E_{0}, \quad a=1 \rightarrow E_{1}, \quad p_{0}=\frac{e^{-E_{0}}}{Z}, \quad p_{1}=\frac{e^{-E_{1}}}{Z}, \quad Z=e^{-E_{1}}+e^{-E_{0}}
$$




$$
\begin{gathered}
\langle a\rangle=\sum a p=0 p_{0}+1 p_{1}=0 \frac{e^{E_{0}}}{Z}+1 \frac{e^{E_{1}}}{Z} \\
\langle a\rangle=\frac{e^{E_{1}}}{Z}=\frac{e^{E_{1}}}{e^{-E_{1}}+e^{-E_{0}}}
\end{gathered}
$$

Dividindo os em cima e em baixo por $e^{-E_{0}}$, encontramos:

$$
\begin{gathered}
\langle a\rangle=\frac{1}{1+e^{-E_{1}-E_{0}}}=\frac{1}{1+e^{-\Delta f}} \\
\langle a\rangle=\left(1+e^{-\Delta f}\right)^{-1}
\end{gathered}
$$

Onde $\Delta f=-E_{1}-E_{0}$. Comparando esse resultado com a equação 2.11, concluímos que [1]:

$$
\Delta f=-f_{m}(m)-F_{L}([L]), \text { sendo } \quad F_{L}([L]) \equiv \ln \frac{1+\frac{[L]}{k_{i}}}{1+\frac{[L]}{k_{a}}}
$$

ou seja, na equação 2.15,

$$
\begin{gathered}
e^{-\Delta f}=e^{f_{m}(m)} \frac{1+\frac{[L]}{k_{i}}}{1+\frac{[L]}{k_{a}}} . \\
\Delta f=-f_{m}(m)-\ln \left(\frac{1+\frac{[L]}{k_{i}}}{1+\frac{[L]}{k_{a}}}\right) .
\end{gathered}
$$

Assim, pela característica e tipo de contribuições de $\Delta f$, na situação de atividade do receptor, podemos enxerga-lo como sendo o análogo do campo magnético no modelo de Ising, dando orientação para os receptores. Tendo em vista que sua contribuição tem características tanto internas da bactéria (dependência do nível de metilização $m$ ), quanto externas (dependência da concentração do ligante $[L]$ ), mantendo sempre sua contribuição independente da interação com seus receptores vizinhos. Desta forma, considerando as possibilidades de estado de cada receptor (ativo e inativo), a interação $J$ que é fator de interação/comunicação entre os receptores de uma mesma bactéria e levando em conta a presença de $\Delta f$ como representação de campo externo, a equação de energia de cada receptor como uma representação do modelo de Ising pode ser montada da seguinte forma:

$$
H(a)=J \sum(2 a-1)(2 a-1)-\Delta f\left(m_{i},[L]\right) \sum a_{i}
$$


Portanto, se considerarmos que a bactéria E. Coli possui uma rede de receptores e que a energia de cada um pode ser dada pela equação 2.20 , onde $a \equiv\left(a_{1}, a_{2}, a_{3} \ldots a_{n}\right)$, podemos verificar que a sensibilidade dos receptores e o processo de comunicação pode ser exemplificado pelo modelo de Ising, sendo que cada receptor terá sua influência sobre seu vizinho imediato, favorecendo assim, a comunicação quando a bactéria estiver na presença de um nutriente.

\subsection{Formulação e estrutura do modelo matemático da quimiotaxia}

O modelo matemático utilizado é semelhante aos já estudados em trabalhos anteriores como Mello (2003A, 2003B), Tu (2013), Shimizu (2010) e Lan, Schulmeister, Sourjik e Tu (2011). Um aspecto comum com os estudos anteriores é a presença de duas escalas de tempo muito diferente, uma relacionada com a ligação do estímulo e da atividade de comutação entre os receptores, outra está relacionada com a metilização dos receptores inativos e a adaptação através dessa mesma metilização. O primeiro, referente à ligação do ligante no receptor e a mudança que define a atividade, que é feito de forma muito rápida, esse processo pode ser considerado um estado estacionário ou em equilíbrio. Já o segundo é considerado um processo lento que para conseguir a adaptação depende do ajuste do nível de metilização. Essa adição e remoção de grupos metílicos são ocasionadas pela atividade média de cada receptor. Sendo assim, vamos analisar a capacidade de adaptação quando existe uma alteração na concentração do estímulo.

Primeiramente devemos considerar que cada receptor pode estar no estado ativo e inativo, sendo que cada receptor $T_{q \vec{m} l a}$ pode depender de quatro parâmetros. $\mathrm{O}$ índice $q$ é um dos cinco quimiorreceptores responsáveis por detectar os estímulos, conforme mencionado na seção 1.5. Assim, $q$ podemos ter $q_{1}=1$ e $q_{2}=0$, onde $q_{1}=1$ é atribuído aos receptores sensíveis às substâncias consideradas como estímulo de ligação, enquanto todos os outros receptores recebem o índice $q_{2}=0$. O índice $l$ pode ser $l=0$, ou $l=1$ para quando o receptor está vago ou ligado por um ligante, respectivamente. O uso do vetor $\vec{m}$ se dá pelo fato de existirem dois modelos para a metilização/desmetilização, modelo sequencial e modelo não sequencial. No modelo sequencial (Figura 14) o nível de metilização deve ser descrito pelo escalar $m$, onde os quatro lugares vagos para os grupos metílicos são preenchidos de forma sequencial. No modelo não-sequencial 


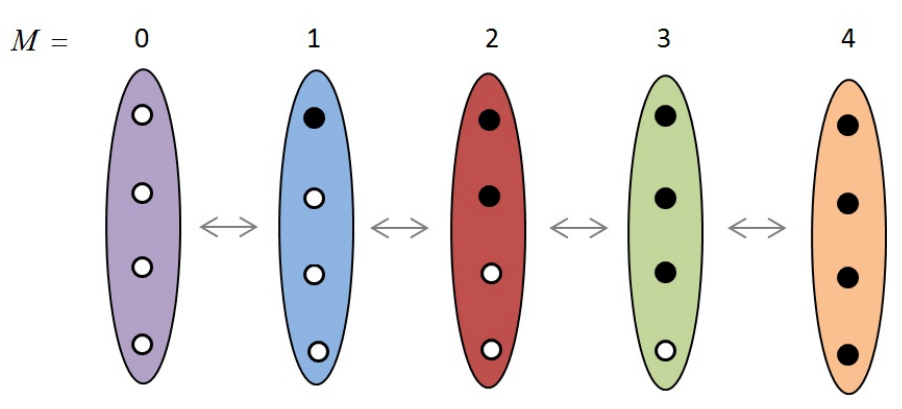

Figura 14 - Esquema de metilização sequencial.

(Figura 15) devemos utilizar o vetor $\vec{m}$, onde cada componente pode ter valor 0 ou 1, pois existem 16 possibilidades de preencher os receptores com os grupos metílicos. Desta forma, no modelo não-sequencial, o estado de metilização é descrito pelo vetor $\vec{m}$ que tem quatro componentes, cada um deles podendo assumir o valor de 1 ou 0 dependendo se algum grupo metílico está presente, ou não. O índice $a$ representa a atividade do receptor, que pode ser $a=1$ para o estado ativo, ou $a=0$ para o estado inativo.

A energia $H_{q \vec{m} l a}$ do receptor é dada por:

$$
H_{q \vec{m} l a}=\mu_{q a} l+\left(E_{q \vec{m}}^{M}+E_{q}^{C}\right) a
$$

onde $E_{q m}^{M}$ é a dependência com os grupos metílicos $m$ e $E_{q}^{C}$ é a dependência da interação com os receptores vizinhos. Toda a energia neste trabalho é escrita em unidades da energia térmica $K_{B} T$.

O potencial do estado ativo $\left(\mu_{q}^{A}\right)$ é encontrado da seguinte maneira: Considerando a energia para os receptores nos estados ativos (equação 2.22),

$$
H_{q \vec{m} l 1}=\mu_{q}^{A} l+\left(E_{q \vec{m}}^{M}+E_{q}^{C}\right)
$$

com o receptor ligado a um ligante $(l=1)$, a probabilidade $P_{\text {qmla }}$ para os estados ativos $(a=1)$ é dado por:

$$
P_{q m 11}=\frac{e^{-\left(\mu_{q}^{A} l+\left(E_{q m}^{M}+E_{q}^{C}\right)\right)}}{Z}, \quad \operatorname{com} \quad Z=e^{-\left(E_{q m}^{M}+E_{q}^{C}\right)}+e^{-\left(\mu_{q a} l+\left(E_{q m}^{M}+E_{q}^{C}\right)\right)}
$$

assim,

$$
P_{q m 11}=\frac{1}{1+e^{+\mu_{q}}}
$$

A probabilidade de ligação de um ligante no receptor depende diretamente da concentração de estímulos no ambiente, quanto maior a concentração maior a chance. 


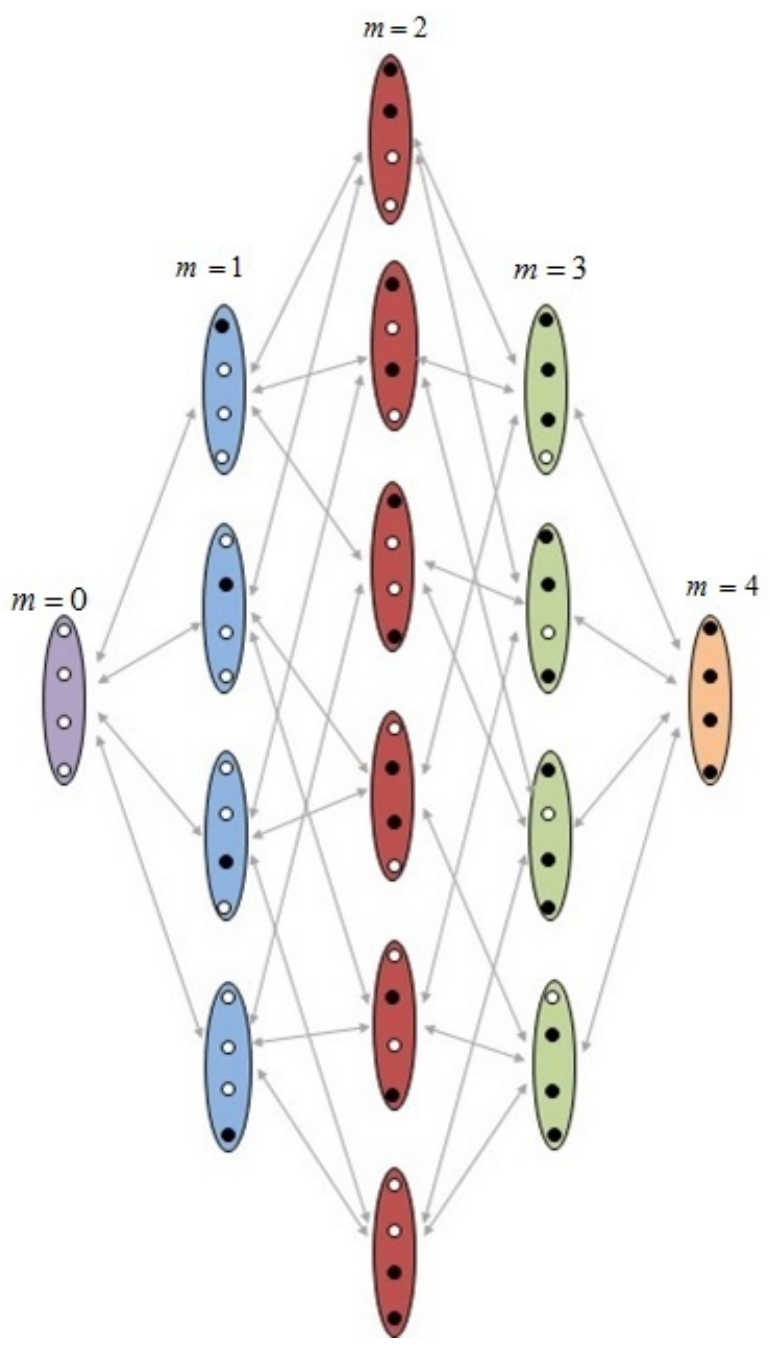

Figura 15 - Esquema de metilização não sequencial.

Sendo a variação da probabilidade no tempo de um receptor ligado a um ligante, dado por:

$$
\frac{d P_{q m l a}}{d t}=-k_{q 1} P_{q m 1 a}+k_{q 0}\left[L_{q}\right] P_{q m 0 a}
$$

onde $k_{q 0}$ e $k_{q 1}$ são constantes de acoplamento e [ $\left.L_{q}\right]$ é a concentração do ligante . Admitindo na equação 2.25 que o receptor no estado estacionário $\frac{d P_{q m l a}}{d t}=0$, podemos encontrar $\left(\mu_{q a}\right)$, conforme abaixo.

$$
-k_{q 1} P_{q m 1 a}+k_{q 0}\left[L_{q}\right] P_{q m 0 a}=0
$$

Definindo $\frac{k_{q 0}}{k_{q 1}}=\frac{1}{K_{q}^{A}}$, pois ambos são constantes de acoplamento, onde o índice $A$ significa ativo, temos:

$$
P_{q m 1 a}=\frac{1}{K_{q}^{A}}\left[L_{q}\right] P_{q m 0 a}
$$




$$
\frac{\left[L_{q}\right]}{K_{q}^{A}}=\frac{P_{q m 1 a}}{P_{q m 0 a}}
$$

usando a equação 2.23 para o receptor no estado ativo, ligado $(l=1)$ e não ligado $(l=0)$ temos

$$
\begin{gathered}
\frac{\left[L_{q}\right]}{K_{q}^{A}}=\frac{P_{q m 11}}{P_{q m 01}}=\frac{e^{-\left(\mu_{q}^{A}+\left(E_{q m}^{M}+E_{q}^{C}\right)\right)}}{e^{-\left(E_{q m}^{M}+E_{q}^{C}\right)}}=e^{-\mu_{q}^{A}} \\
\frac{\left[L_{q}\right]}{K_{q}^{A}}=e^{-\mu_{q}^{A}} \\
\mu_{q}^{A}=\ln \frac{K_{q}^{A}}{\left[L_{q}\right]}
\end{gathered}
$$

Podemos ver claramente a relação direta da equação 2.28 com a equação 1.7 mostrado na seção 1.2. Ambas trazem a razão de ligantes em seus respectivos conceitos, na primeira, entendemos como a razão entre a população de receptores ligados e não ligados, já na segunda a razão está relacionada entre as proteínas ligadas. Outro ponto em comum é o mesmo comportamento das duas equações, conforme abaixo:

Considerando a equação 2.24 e a equação 2.31 , temos:

$$
\begin{aligned}
P_{q \vec{m} 11} & =\frac{1}{1+e^{\ln \frac{K_{q}^{A}}{\left[L_{q}\right]}}} \\
& =\frac{1}{1+\frac{K_{q}^{A}}{\left[L_{q}\right]}} \\
& =\frac{1}{\frac{\left[L_{q}\right]+K_{q}^{A}}{\left[L_{q}\right]}} \\
& =\frac{\left[L_{q}\right]}{\left[L_{q}\right]+K_{q}^{A}}
\end{aligned}
$$

sendo idêntica à equação 1.8, portanto, a constante de dissociação $k_{q}^{A}$ tem o mesmo comportamento com os ligantes livres (seção 1.2) no processo da quimiotaxia bacteriana.

Na equação $H_{q \vec{m} l a}=\mu_{q a} l+\left(E_{q \vec{m}}^{M}+E_{q}^{C}\right) a$, quando o ligante não está ligado ao receptor, a energia do estado ativo é maior que a energia do estado inativo, devido o valor de $E_{q \vec{m}}^{M}$ que depende do estado de metilização e pelo valor de $E_{q}^{C}$ que depende da interação dos vizinhos.

Conforme usado por Mello (2003B), Lan, Schulmeister, Sourjik e Tu (2011) assumimos que o potencial químico $\mu_{q a}$ é constante para cada tipo de ligante $q$, independente 
do nível de metilização, e que todos os sítios de metilização $m$ contribuem linearmente para a energia livre $E_{q \vec{m}}^{M}$. Assim teremos:

$$
E_{q \vec{m}}^{M}=\alpha_{q}\left(|\vec{m}|-m_{q 0}\right)
$$

onde $\alpha_{q}$ quantifica a mudança na diferença de energia entre os estados ativos e inativos , provocada pela adição de um grupo metílico, $m_{q 0}$ representa o nível médio de metilização, na ausência de qualquer estímulo [21]. A norma de $m$ é:

$$
|\vec{m}|=\sum_{i=1}^{M} m_{i}
$$

O efeito da energia de interação dos vizinhos mais próximos é descrito pela soma,

$$
E_{q}^{C}=\sum_{i \in n . n .} C_{q q_{i}}\left(a_{i}-0.5\right)
$$

onde n.n. representa os vizinhos mais próximos (nearest neighbors). A constante de acoplamento identificada por $C_{q q_{i}}$ depende da interação que ocorre entre os tipos de receptores $q$ e $q_{i}$. Assim como Lan, Schulmeister, Sourjik e Tu (2011), neste trabalho, consideramos a simetria da força de acoplamento $C_{q q^{\prime}}=C_{q^{\prime} q}$. O 0.5 é para preservar a simetria entre os estados ativos e inativos. Assim, na equação 2.21, quando o estado de um receptor é alterado, podemos considerar a simetria e representar a contribuição dos receptores vizinhos por:

$$
E_{q}^{C} a=\sum_{i \in n . n .} C_{q q_{i}}\left(a_{i}-0.5\right) a=\sum_{i \in n . n .} C_{q q_{i}}\left(a_{i}-0.5\right)(a-0.5)+0.5 \sum_{i \in n . n .} C_{q q_{i}} a_{i}
$$

com exceção de um termo constante que não afeta na dinâmica. Usando esta expressão podemos descrever a equação para o sistema total de forma simétrica.

$$
H=\sum_{i}\left[\mu_{q_{i} a_{i}} l_{i}+\left(E_{q_{i} \vec{m}_{i}}^{M}+\frac{1}{2} \sum_{j n . n . i} C_{q_{i} q_{j}}\right) a_{i}+\frac{1}{2} \sum_{j n . n . i} C_{q_{i} q_{j}}\left(a_{i}-0.5\right)\left(a_{j}-0.5\right)\right]
$$

Com a existência da influência da interação entre os receptores com a energia externa, o termos $\sum_{j n . n . i} C_{q_{i} q_{j}}$ introduzem uma inohomogeneidade que pode ser substituída por um efeito médio.

$$
\sum_{j n . n . i} C_{q_{i} q_{j}} \approx N_{n . n .} \sum \frac{P_{q}}{P} C_{q_{i} q}
$$


definindo

$$
E_{q_{i} \vec{m}_{i}}^{M^{\prime}} \equiv E_{q_{i} \vec{m}_{i}}^{M}+\frac{N_{n . n .}}{2} \sum \frac{P_{q}}{P} C_{q_{i} q}
$$

com isso, levaremos em conta apenas um campo efetivo e assim, podemos reescrever a equação 2.37 como:

$$
H=\sum_{i}\left[\mu_{q_{i} a_{i}} l_{i}+E_{q_{i} \vec{m}_{i}}^{M^{\prime}} a_{i}+\frac{1}{2} \sum_{j n . n . i} C_{q_{i} q_{j}}\left(a_{i}-0.5\right)\left(a_{j}-0.5\right)\right]
$$

Devido a um maior detalhamento e individualização das energias envolvidas nesse sistema, a equação 2.40 é mais apropriada quando se pretende trabalhar usando o método Monte Carlo, pois o MC junto com a evolução de Metrópolis utiliza uma variação de energia específica. Já para trabalhos que utililizam o campo médio a equação 2.21 é mais apropriada.

A metilização dos sítios vazios feita por CheR, ocorre apenas quando o receptor está no estado inativo, ou seja, $a=0$, enquanto grupos metílicos só são removidos por CheB quando o receptor está no estado ativo, $a=1$. No modelo sequencial a metilização é descrita por:

$$
T_{q m l a} \stackrel{(1-a) k_{R}}{\underset{a k_{B}}{\rightleftharpoons}} T_{q(m+1) l a}
$$

No modelo de metilização não sequencial a metilização de um dado receptor, $T_{q \vec{m} l a}$, muda de acordo com a seguinte equação:

$$
T_{q \vec{m} l a} \stackrel{(1-a) k_{R}}{\underset{a k_{B}}{\rightleftharpoons}} T_{q\left(\vec{m}+\vec{e}_{i}\right) l a}
$$

Onde $i \in\{1 \ldots M\}$ e $m_{i}=0 . e_{i}$ são os quatro vetores unitário, um para cada local de metilização. $k_{R}$ e $k_{B}$ são as taxas de metilização e desmetilização, referente a CheR e CheB. Dessa forma, representa a possibilidade de que cada sítio livre seja metilizado.

\subsection{Comunicação inter-receptor e influência na adaptação}

A existência de modelos que possam descrever o comportamentos e a cooperação entre os receptores e assim explicar o mecanismo da sensibilidade das bactérias é um ponto muito importante no estudo da quimiotaxia. Entre os modelos existentes, os 
mais estudados são os modelos Monod-Wyman-Changeux (MWC) e o modelo de Ising. Evidências experimentais e teóricas da adequação do modelo de Ising para explicar o comportamento dos receptores foram fornecidas por Sourjik e Berg [29] e por Mello e Tu [31]. O modelo de MWC foi proposto como uma alternativa [25], mas experiências recentes resolveram a questão a favor do modelo de Ising, tendo em vista as limitações propostas pelo modelo de MWC [21].

Sistemas sensoriais normalmente possuem a capacidade de detectar uma alteração na concentração dos estímulos, capacidade vantajosa também para a detecção de sinais moleculares das células [32]. Neste trabalho mostrou-se, através de simulações, que a sensibilidade, entre os receptores, é muito maior nos receptores acoplados quando comparado com os receptores desacoplados. O acoplamento dos receptores formam um modelo ideal, fazendo com que as células detectem e respondam aos estímulos extracelulares [32]. A E. Coli é um exemplo desse processo, pois estudos mostraram que ela tem elevada sensibilidade a diversas variedades de atraentes. Assim, uma análise feita a partir de uma matriz bidimensional de receptores quimiotáticos, usando o modelo de Ising, mostrou que as propriedades de cooperação, feitas pelo acoplamento dos receptores, podem ser produzidas simplesmente utilizando a interação entres os receptores vizinhos mais próximos [32].

Para Duke et al (1999), a sensibilidade de um conjunto de receptores independentes (desacoplados) é diretamente proporcional a alteração na ocupação. Assim, para um sistema linear não existe uma maneira de melhorar a sensibilidade nos extremos sem afetar negativamente a resposta no meio da faixa, figura 16 [32].

Já no sistema com os receptores acoplados ocorre um aumento da sensibilidade, tanto nas baixas ou grandes concentrações de ligantes. Se o receptor está em uma área onde a concentração de ligantes é baixa, os receptores que se ligarem aos ligantes ficarão inativos e tenderão a deixar inativos os receptores vizinhos. Conforme já visto anteriormente, receptores inativos tendem a receber grupos metílicos para que se tornem ativos novamente. Essa atividade também é sentida pelos receptores vizinhos (base para a adaptação). Em um ambiente onde existe uma maior concentração de ligantes o processo se torna semelhante ao acima, pois os receptores já estão ligados e consequentemente inativos. Assim, os receptores irão sofrer novamente a adição de grupos metílicos e a sensibilidade, entre os receptores, fará com que os vizinhos mais 


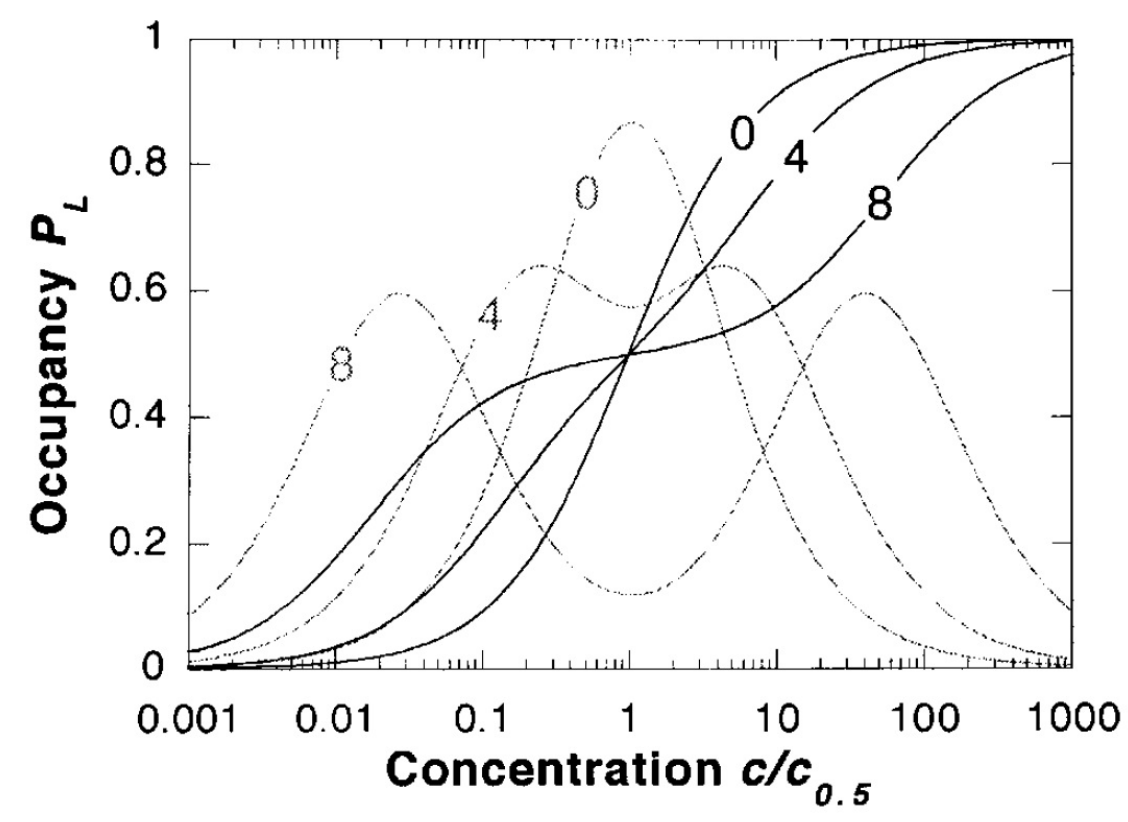

Figura 16 - Razão de receptores ocupados por moléculas de ligante, em função da concentração de ligante do ambiente [32].

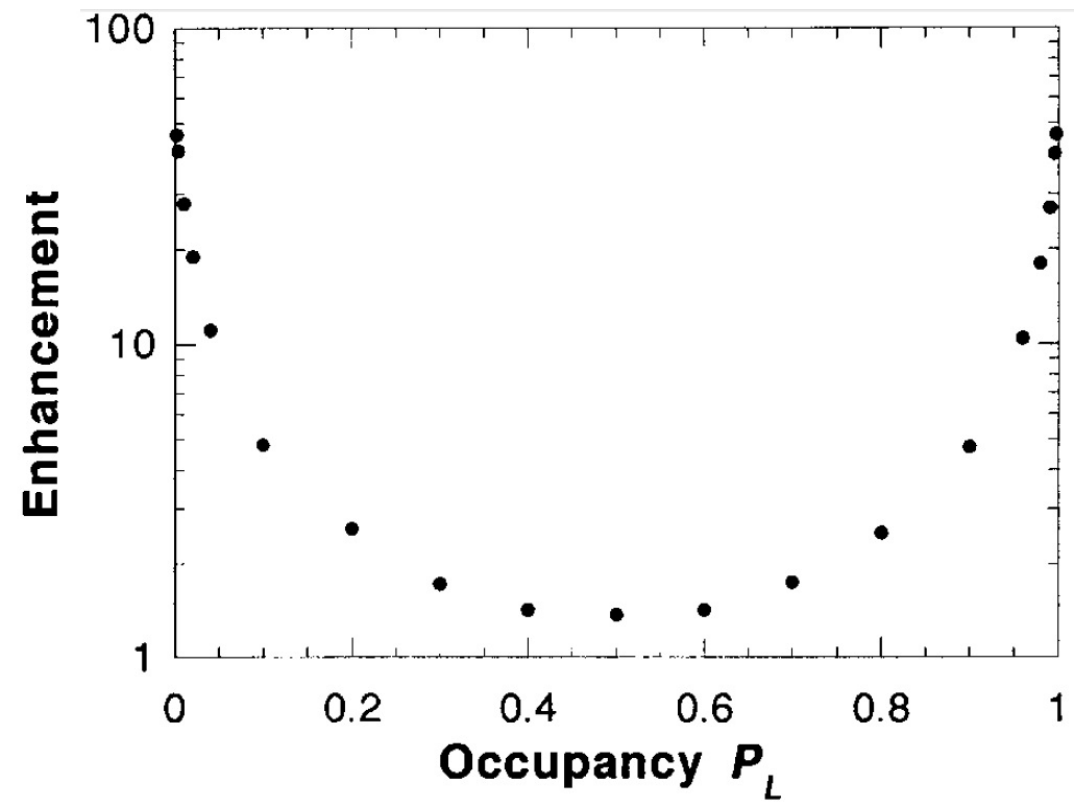

Figura 17 - Razão de receptores ocupados por moléculas de ligante, em função da concentração de ligante do ambiente [32], com adaptação.

próximos sejam influenciados por este estado de atividade. Desta maneira, sistemas com receptores acoplados demontram que em ambientes com pouca ou muita concentração de ligantes a sensibilidade é alta (figura 17).

Através dos efeitos combinados de acoplamento entre os receptores vizinhos e a adaptação, a informação entre os receptores é autorregulada, fazendo com que as respostas sejam sentidas somente quando necessário, seja em baixa ou em alta 
concentração de ligante [32].

\subsection{Adaptação perfeita}

Conforme visto na seção 1.8 a adaptação perfeita independe da concentração de ligantes. No entanto, ela é diretamente influenciada pelo estado de atividade do receptor, ativo ou inativo. Sendo esses estados dependentes da inserção ou retirada de grupos metílicos nos receptores. Desta forma o papel CheR e CheB, proteínas responsáveis pela metilização e desmetilização, respectivamente, são primordiais para se alcançar a perfeita adaptação na quimiotaxia.

A atividade dos receptores depende do nível de metilização, no entanto, a origem desta dependência permanece obscura. Partindo deste principio e considerando que um receptor pode adaptar-se a uma determinada concentração de ligantes ajustando seu nível de metilização podemos montar o modelo matemático da população de receptores assumindo que o a taxa de metilização diminui com a atividade do receptor e aumenta com a inatividade.

A população de cada receptor é descrita pela probabilidade dada por $P_{q \vec{m} a l}$, onde cada receptor pode variar de acordo com o estado de $q, m, a$ e $l$, seguindo as seguintes equações:

$$
\begin{aligned}
P_{q \vec{m} a} & =\sum_{l=0}^{1} P_{q \vec{m} a l} \\
P_{q \vec{m}} & =\sum_{a=0}^{1} P_{q \vec{m} a} \\
P_{q} & =\sum_{\vec{m}} P_{q \vec{m}} \\
P & =\sum_{q} P_{q}
\end{aligned}
$$

como a quantidade de cada tipo de receptor é fixa, $P$ e $P_{q}$ são considerados constantes, enquanto as outras probabilidades (2.43 e 2.44) evoluem durante a simulação.

Dessa forma, para simular a dinâmica de metilização sequencial, na qual $\vec{m}$ pode ser substituída por $m$, não é necessário descrever detalhadamente a população $P_{\text {qmal }}$, para isso, basta sabermos o comportamento de $P_{q m}$ e a atividade média $\left(\langle a\rangle_{q}\right)$. Assim, 


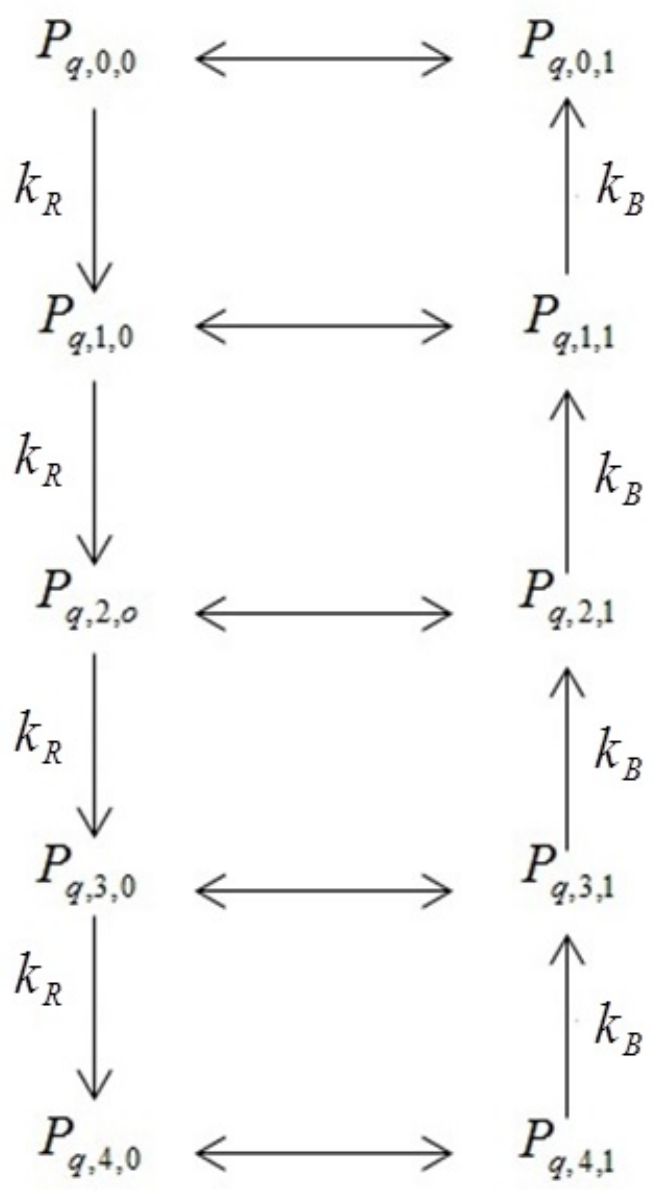

Figura 18 - Esquema simplificado do modelo sequencial, mostrando a população de receptores e seus possíveis caminhos após metilizados/desmetilizados, lembrando que CheR só age em receptores inativos e CheB nos ativos.

podemos descrever o processo de adaptação, como sendo caracterizado pela dinâmica da população de receptores $\left(P_{q m}\right)$, sendo $q$ o tipo de estímulo do receptor e $m$ os sítios metílicos, onde $m \in(0,1,2,3,4)$. Para isso, devemos considerar que a adição e subtração de grupos metílicos seguem um modelo sequencial e que $\langle a\rangle$ é a atividade media na presença de um tipo $q$ de estímulo. Portanto, considerando que:

$$
P_{q m} \rightarrow P_{q m 0}+P_{q m 1}
$$

onde $P_{q m 0}$ e $P_{q m 1}$ são respectivamente as populações de receptores no estado inativo e ativo e que todas as combinações, obedecem um modelo sequencial, conforme Figura 18.

O regime estacionário pode facilmente ser descrito, considerando que a taxa de variação temporal seja nula, ou seja, $\frac{d P_{q m}}{d t}=0$. Assim,

$$
\frac{d P_{q 0}}{d t}=+k_{B} P_{q 11}-k_{R} P_{q 00}=0
$$




$$
\begin{gathered}
\frac{d P_{q 1}}{d t}=+k_{R} P_{q 00}+k_{B} P_{q 21}-k_{B} P_{q 11}-k_{R} P_{q 10}=0 \\
\frac{d P_{q 2}}{d t}=+k_{R} P_{q 10}+k_{B} P_{q 31}-k_{B} P_{q 21}-k_{R} P_{q 20}=0 \\
\frac{d P_{q 3}}{d t}=+k_{R} P_{q 20}+k_{B} P_{q 41}-k_{B} P_{q 31}-k_{R} P_{q 30}=0 \\
\frac{d P_{q 4}}{d t}=+k_{R} P_{q 30}-k_{B} P_{q 41}=0
\end{gathered}
$$

onde $k_{R}$ é a taxa de adição de grupos metílicos e $k_{B}$ é a taxa de remoção de grupos metílicos.

A metilização média $\langle m\rangle_{q}$ dos receptores $q$ pode ser escrita como:

$$
\langle m\rangle_{q}=\frac{\sum_{m=0}^{M} m P_{q m}}{\sum_{m=0}^{M} P_{q m}}=\frac{1}{P_{q}} \sum_{m=0}^{M} m P_{q m}, \quad \text { onde } \quad P_{q}=\sum_{m=0}^{M} P_{q m}
$$

dessa forma, podemos encontrar a taxa de metilização no tempo, derivando em ambos os lados:

$$
\frac{d\langle m\rangle_{q}}{d t}=\frac{1}{P_{q}} \sum_{m=0}^{M} m \frac{d P_{q m}}{d t}
$$

Usando o valor de $\frac{d P_{q m}}{d t}$ para cada estado de metilização do receptor, conforme equações 2.48 , 2.49, 2.50, 2.51 e 2.52 temos,

$$
\begin{aligned}
\frac{d\langle m\rangle_{q}}{d t}=\frac{1}{P_{q}} & {\left[0\left(+k_{B} P_{q 11}-k_{R} P_{q 00}\right)\right.} \\
& +1\left(+k_{R} P_{q 00}+k_{B} P_{q 21}-k_{B} P_{q 11}-k_{R} P_{q 10}\right) \\
& +2\left(+k_{R} P_{q 10}+k_{B} P_{q 31}-k_{B} P_{q 21}-k_{R} P_{q 20}\right) \\
& +3\left(+k_{R} P_{q 20}+k_{B} P_{q 41}-k_{B} P_{q 31}-k_{R} P_{q 30}\right) \\
& \left.+4\left(+k_{R} P_{q 30}-k_{B} P_{q 41}\right)\right]
\end{aligned}
$$

Assim, fazendo os cancelamentos necessario, temos,

$$
\begin{aligned}
\frac{d\langle m\rangle_{q}}{d t}= & \frac{1}{P_{q}}\left[k_{R} P_{q 00}-k_{B} P_{q 21}-k_{B} P_{q 11}+k_{q 10}\right. \\
& \left.\quad-k_{B} P_{q 31}+k_{R} P_{q 20}-k_{B} P_{q 41}+k_{R} P_{q 30}\right]
\end{aligned}
$$




$$
\begin{gathered}
\frac{d\langle m\rangle_{q}}{d t}=\frac{1}{P_{q}}\left[k_{R}\left(P_{q 00}+P_{q 10}+P_{q 20}+P_{q 30}\right)\right. \\
\left.\quad-k_{B}\left(P_{q 11}+P_{q 21}+P_{q 31}+P_{q 41}\right)\right] \\
\frac{d\langle m\rangle_{q}}{d t}=\frac{1}{P_{q}}\left[k_{R}\left(P_{q I}-P_{q 40}\right)-k_{B}\left(P_{q A}-P_{q 01}\right)\right] \\
=k_{R} \frac{P_{q I}}{P_{q}}-k_{B} \frac{P_{q A}}{P_{q}}-k_{R} \frac{P_{q 40}}{P_{q}}+k_{B} \frac{P_{q 01}}{P_{q}} \\
=k_{R}\left(1-\langle a\rangle_{q}\right)-k_{B}\langle a\rangle_{q}-k_{R} P_{40}+k_{B} P_{01}
\end{gathered}
$$

Se a população dos receptores $P_{01}$ e $P_{40}$ for pequena, ou seja, se

$$
P_{01} \ll 1, \quad P_{40} \ll 1
$$

estes termos podem ser desconsiderados da equação 2.58 [21]. Para que esta situação aconteça são necessárias duas condições: que não hajam receptores inativos com $m=4$ e que não hajam receptores ativos com $m=0$. Essas também são satisfeitas, de forma mais restritivas, quando a população de receptores nos estados $m=0$ e $m=4$ é baixa.

Quando o sistema se adapta, ele atinge um estado estacionário, onde $\frac{d m}{d t}=0$, devido ao equilíbrio de adição e subtração de grupos metílicos por CheR e CheB serem aproximadamente iguais em quantidades. Estudando a média da metilização podemos considerar então que $\frac{d\langle m\rangle_{q}}{d t}=0$, ou seja,

$$
\begin{gathered}
\frac{d\langle m\rangle_{q}}{d t}=k_{R}-k_{R}\langle a\rangle_{q}-k_{B}\langle a\rangle_{q} \\
0=k_{R}-\left(k_{R}+k_{B}\right)\langle a\rangle_{q} \\
\langle a\rangle_{q}=\frac{k_{R}}{k_{R}+k_{B}}
\end{gathered}
$$

desta forma, a equação 2.62 nos mostra a atividade média sem dependência da concentração de ligando, ou seja, a adaptação perfeita [21] se as condições da equação 2.59 forem satisfeitas. Fica demonstrado que o sistema de equações que representa esse modelo, com metilização sequencial, leva a adaptação perfeita.

Portanto, a adaptação é o mecanismo biológico responsável pelo ajuste contínuo em resposta às alterações na concentração do estímulo significativo [24]. Isto é conseguido através da adição ou remoção de grupos metílicos nos sítios de metilização. 
As condições que o modelo da quimiotaxia devem cumprir para apresentar perfeita adaptação foram discutidos em [28], onde o estado de metilização é descrito pela variável $m \in\{0 \ldots M\}$, onde $M$ é o número de sítios do receptor que pode ocorrer a adição de grupos metílicos. Esta representação de metilização é muito utilizada em simulações de quimiotaxia [21] e [30].

A variável $m$ escalar só pode ser usado para descrever o nível de metilização, se os quatro sítios estão ocupados sequencialmente . De outro modo, a metilização deve ser descrita por um vetor $\vec{m}$, com quatro elementos, cada um deles assumindo o valor 0 ou 1, conforme mencionado na seção 2.1. Isto não é uma questão de menor importância, tendo em vista que a adaptação perfeita (equação 2.62) só pode ser obtida através da ocupação sequencial dos sítios de metilização [28].

Se impusermos o modelo sequencial, apenas 5 estados são possíveis (figura 14). Caso seja permitida a metilização fora da ordem, 16 estados (Figura 15) serão permitidos. Essas figuras também mostram quais estados são acessíveis pela metilização ou desmetilização de outro estado.

Em outro trabalho, Mello (2003A) descreve seis condições necessárias para que ocorra perfeita adaptação, são elas: a escala de tempo para ligação do ligante ao receptor deve ser muito menor do que a a escala de tempo da fosforilação dada pela metilização; as taxas de metilização/desmetilização estão linearmente relacionadas pela atividade do receptor, sendo zero para $m=4$ e $m=0$; a atividade dos receptores não metilados e os com metilização máxima são independentes da presença de ligantes; a relação entre $k_{R}$ relacionado a CheR e $k_{B}$ relacionado a CheB-P (CheB Fosforizado) são as mesmas para todos os estados de metilização; a taxa de transferência do grupo fosfato de CheA para CheB e CheY é proporcional a auto fosforilação de CheA; com a taxa de metilização e desmetilização sendo iguais podemos desconsiderar a dependência dos receptores não ligados.

A adaptação dos receptores no mecanismo da quimiotaxia proporciona vantagem competitiva relevante. Provavelmente desempenharam um papel importante na evolução da rota da quimiotaxia. 



\section{Método}

\subsection{Método Monte Carlo}

O avanço tecnológico trouxe infinitos benefícios para o desenvolvimento científico e, um exemplo claro, são as diversas maneiras possíveis de manipular os experimentos através das simulações. Com o aumento das complexidades descobertas, nos problemas reais, a simulação está cada vez mais sendo utilizada em várias áreas do conhecimento, tornando assim, uma saída para sistemas complexos que não possuem uma resposta analítica. Para Garcia, Lustosa e Barros (2010), a simulação consiste no desenvolvimento de um modelo ou representação de uma situação real, que possibilita a realização de experimentos em diversos cenários, sendo uma ferramenta de auxílio na avaliação do sistema, fornecendo uma melhor compreensão ao invés de gerar apenas uma solução. Para Andrade (1989) a simulação pode ser usada para experiências com novas situações, mesmo tendo pouca, ou nenhuma informação, com o intuito de preparar para o que possa acontecer no processo real.

Existem dois tipos de modelos de simulação: o determinístico e o probabilístico. No determinístico pressupõe que os dados são obtidos com certeza, não levando em conta que os dados possam ter alterações futuras. No probabilístico, é baseado na tentativa de se encontrar a natureza probabilística envolvida nas variáveis do sistema [33].

Os modelos de simulações probabilísticas tiveram inicio com o método de Monte Carlo que tem como foco simulações de fenômenos aleatórios. Esse nome é devido ao famoso cassino de Monte Carlo, no Principado de Mônaco. Seu desenvolvimento foi iniciado em 1944, durante a Segunda Guerra Mundial, sendo ferramenta de pesquisa para o desenvolvimento da bomba atômica [33].

A primeira publicação sobre método de MC é datada de 1949, contando-se os dias atuais mais de 22.969 publicações sobre este tema. Este crescimento se deve ao grande avanço tecnológico dos computadores que trouxeram um grande aumento na velocidade de processamento e na capacidade de armazenamento das informações [34]. Hammersley e Handscomb (1964) definem o Método de Monte Carlo como a parte da 
matemática experimental que está preocupada em experiências com números aleatórios. Já Yariyaz (2009) define como um método estatístico, no qual se utiliza uma sequência de números aleatórios para a realização de simulações. Desta forma, podemos ver que a aplicação deste método é conhecida em diversas áreas, seja para descrever fenômenos físicos ou para encontrar soluções matemáticas de sistemas complexos.

Em muitas aplicações práticas do método de Monte Carlo, não existe a necessidade de se escrever as equações matemáticas que representam o sistema, sendo necessário apenas que o processo físico possa ser descrito por uma densidade de probabilidade [34]. Desta forma, este método é uma expressão geral, onde as formas de investigação estão baseadas no uso de números fortuitos com estatísticas de probabilidade [33].

No entanto, podem existir algumas dificuldades quando estamos usando o método de Monte Carlo. Uma das principais e que podem acabar gerando o não desenvolvimento do projeto, até mesmo antes de se começar a pensar na simulação, é a capacidade de memória e a velocidade de processamento da CPU. Uma simulação que requer anos para "executar" é totalmente impraticável. Da mesma forma, um cálculo que requer memória maior que o limite existente, somente poderá ser realizado com técnica de programação sofisticada e isso pode retardar a velocidade e aumentar as chances de erros [35]. Ainda para Landau e Binder (2005), existem outras dificuldades que podem influenciar nos resultados das simulações, tais como: erros de truncamento e arredondamento, erros estatísticos e erros sistemáticos.

O método de Monte Carlo constitui basicamente numa grande amostragem aleatória com o intuído de obter resultados numéricos, onde quanto maior for a amostra melhor será o resultado obtido. O método é alimentado por um gerador de número aleatório utilizado para amostragem dos vários fenômenos que ocorrem durante os processos de interesse. Sendo essas amostragens realizadas através das distribuições de probabilidade, conforme Figura 19.

\subsection{Metodologia}

Como a adição e subtração de grupos metílicos (metilização) são os responsáveis pela atividade dos receptores (seção 1.8), será através dessa ação que buscaremos encontrar a adaptação da quimiotaxia na bactéria Escherichia Coli. Assim, usando o 


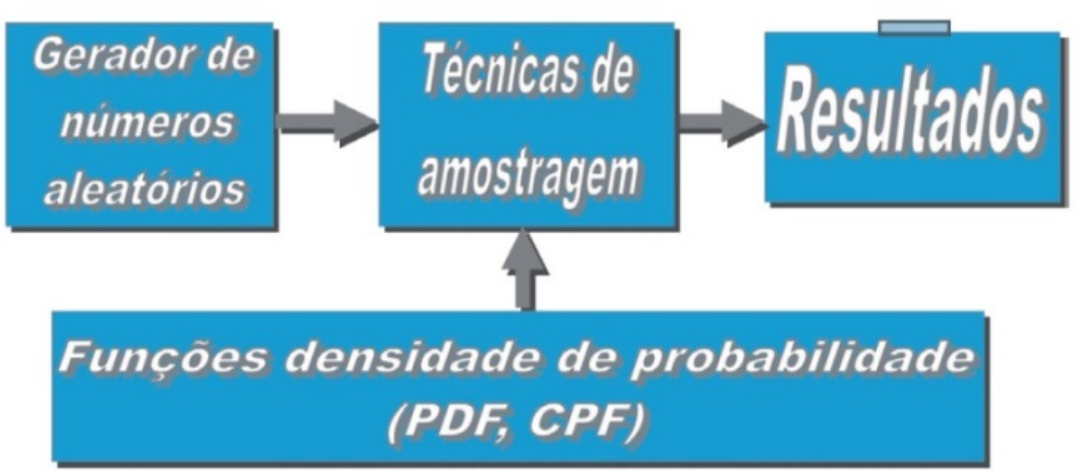

Figura 19 - Esquema simplificado de uma simulação utilizando o método Monte Carlo [34].

modelo Monte Carlo junto com o algoritmo de Metropolis (capaz de gerar uma variação aleatória através de uma probabilidade) iremos simular o processo de metilização. A simulação será realizada através de uma rede quadrada com condição de contorno periódico (pontas opostas identificam-se umas com as outras) de $64 \times 64=4.096$ receptores. Cada receptor contém 8 variáveis binárias $a \in 0,1, l \in 1,0, q \in 0,1 \mathrm{e}$ $m_{i} \in 0,1$. Onde, no modelo sequencial $M \in 0 \ldots 4$. Os parâmetros $k, C, L, \alpha$ e $m_{0}$, em princípio, terão os valores retiradas de estudos anteriores. A variação de alguns parâmetros traçam os resultados de nossa simulação.

Tabela 2 - Parâmetros usados na simulação

\begin{tabular}{lr|lr}
\hline NOMES & VALORES & NOMES & VALORES \\
\hline$n$ & 64 & & \\
$q_{1}$ & 0 & $q_{2}$ & 1 \\
$a_{1}$ & 0 & $a_{2}$ & 1 \\
$K_{q_{1} a_{1}}$ & 18.1 & $K_{q_{1} a_{2}}$ & 53.995 \\
$K_{q_{2} a_{1}}$ & 6 & $K_{q_{2} a_{2}}$ & 60.26 \\
$C_{1,1}$ & -1 & $C_{1,2}$ & -1 \\
$C_{2,1}$ & -1 & $C_{2,2}$ & -1 \\
$k_{r}$ & 1 & $k_{b}$ & 2 \\
$L_{0}$ & 0.1 & $L_{1}$ & 1 \\
$\alpha_{1}$ & -3 & $\alpha_{2}$ & -3 \\
$m_{00}$ & 1 & $m_{10}$ & 1 \\
\hline
\end{tabular}

Na tabela 2 vemos os valores dos parâmetros usados na nossa simulção, onde $n$ é o número de receptores em uma matriz $n \times n ; q$ é o tipo de receptores; $a$ é a atividade (0 para inativo e 1 para ativo); $k$ é a constante de dissociação (que depende do tipo de receptor e da atividade); $C$ é a interação entre o receptores vizinhos; $k_{r}$ e $k_{b}$ são responsáveis, respectivamente, pela adição e subtração de grupos metílicos; $L_{0}$ é a concentração dos estímulos; $\alpha$ mudança na diferença de energia entre os estados ativos e inativos, provocada pela adição de um grupo metílico e o $m_{0}$ é o nível médio da metilização, na ausência de qualquer estímulo, responsável por deslocar da esquerda 
para direita da origem.

Na simulação utilizamos a equação 2.40, separada em duas partes, uma que representa a energia de fatores externos ao receptor, tais como: concentração de estímulos, constante de dissociação e a dependência com os grupos metílicos. A outra parte da equação representa a interação existente entre os receptores, independetemente das preferência de ligação existente, isto é, não depende do tipo de receptor ou estímulo.

Em cada etapa do modelo de Monte Carlo um receptor é aleatoriamente selecionado e os dois procedimentos seguintes são executados:

Passo Atividade/Ligando: Uma das variáveis de $a$ ou $l$ é selecionado, com a mesma probabilidade de ser trocada. Será calculada a variação de energia $\Delta E$ entre a energia inicial e a energia do estado ligado. Se $\Delta E \leq 0$ o novo estado é aceito, caso contrário, ele é aceito com probabilidade $e^{-\Delta E}$.

Passo de metilização: Se $a=0$, cada sítio vazio pode ser metilizado com a probabilidade $k_{R} \Delta t$. Se $a=1$, cada sítio ocupado pode ser desmetilado com probabilidade $k_{B} \Delta t$. Um número aleatório diferente é gerado para implementar a probabilidade de cada sitio de metilização. O passo de metilização deve considerar os estados acessíveis de acordo com as figuras 14 e 15.

Na quimiotaxia, o processo de conexão dos estímulos aos receptores é um processo instantâneo, sendo a adição/subtração de grupos metílicos um processo lento, conforme vimos na seção 2.1. Assim, para obedecer essa regra da quimiotaxia, implementamos no programa uma condição, onde para cada 10 vezes rodado o "passos atividade/Ligando"(responsável por calcular a variação da energia), apenas uma vez é rodado o "passo de metilização"(responsável pelo cálculo da probabilidade de metilização). Dessa maneira, para o processo de metilização, a ligação dos estímulos comporta-se como se sempre estivesse em equilíbrio.

Para esta simulação a concentração de estímulos $\left(L_{0}\right)$ varia de $10^{-1}$ a $10^{8}$. Neste intervalo pudemos visualizar todo o comportamente do sistema da E. Coli, desde as adaptações até a faixa onde o sistema não é capaz de responder mais ao aumento da concentração. Consideramos também o tempo de simulação $(t)$, sendo baseado em "unidade de tempo"que varia de $t=0$ a $t=100$. Com esse valor, podemos varrer toda a concentração de estímulo, conseguindo analisar os aspectos individuais da simulação. 
Esta simulação será capaz de mostrar o comportamento dos sítios de metilização, depois de implementado os passos. Poderemos ver o comportamento da bactéria E.Coli quando ela está na presença de atraentes-químicos e a importância da sua estrutura interna para se adaptar ao meio em que vive.

O objetivo da simulação é a geração de arquivos de dados, onde através deles poderemos construir os gráficos necessários para analisar o sistema como um todo. 

Parte II

Resultados 



\section{Resultados, Análise e Discussão}

Neste capítulo, apresentaremos os resultados obtidos nas simulações e a análise. Este trabalho é baseado em um programa computacional em $\mathrm{C}++$, utilizando simulação Monte Carlo, rodado em um computador pessoal com o sistema operacional Linux versão 14.04 LTS, os gráficos obtidos foram feitos no gnuplot.

Nos capítulos e sessões anteriores, comentamos a importância da quimiotaxia para a evolução das bactérias, sendo que o processo de adaptação quimiotática das bactérias ao meio em que vivem é um dos principais responsáveis por essa evolução. Diante disso, quatro fatores são primordiais para descrever esse processo da adaptação, sendo eles: a atividade dos receptores, a concentração de estímulos, os receptores que estão ligados por estes estímulos e a metilização/desmetilização dos receptores. Vale lembrar que a metilização/desmetilização ocorre através da adição e subtração de grupos metílicos no receptor.

A simulação é baseada nos parâmetros fornecidos na tabela 2. A simulação tem sua evolução vinculada ao aumento da concentração de ligantes ([L0]) variando de $10^{-1}$ a $10^{8}$, que por sua vez, têm dependência com o aumento da unidade de tempo $t$. Assim, a população de [L0] têm sua quantidade aumentada em 10 vezes a cada 10 unidades de tempo, tempo suficiente para que a atividade possa se adaptar e retorne para a atividade anterior, conforme pode ser visualizado na figura 20. A cada aumento de $[L 0]$, receptores são preenchidos por ligantes o que faz com que o número de receptores ligados cresça com o aumento de [LO]. A variação de [LO] para esta simulação é aquela necessária par abranger, desde os receptores completamente desligados aos completamente ligado que, para as constantes usadas no experimento correspondem ao intervalo $[L 0]=10^{-1} \ldots 10^{8}$. As grandezas medidas na simulação, tais como atividade, receptores ocupados e metilização são dadas por suas médias, ou frações das somas dessas gradezas pelo total de receptores do sistema. Para o cálculo da atividade e dos receptores ocupados é feita uma média para todos os receptores e para a metilização é considerada a população média em cada grupo metílico ( $M 0, M 1, M 2, M 3$ e M4). Já para a concentração de ligantes são considerados dois tipos de estímulos, no qual, neste trabalho, são simultaneamente excitados com valor inicial de 0.1. 
Sabemos que a adaptação perfeita, como mencionado na seção 2.5, somente é conseguida se consideramos que o sistema obedeça ao modelo sequencial na metilização, ou seja, que existe uma ordem preestabelecida que deve ser cumprida ao adicionar e subtrair grupos metílicos dos receptores, conforme mostrado na figura 14. É preciso considerar também que a atividade média após a adaptação não deve depender da quantidade de estímulos existente no ambiente.

A figura 20 estabelece uma visão geral do comportamento do sistema, no entanto, é muito complicada para que seja feita uma análise detalhada. Por este motivo, os dados contidos nela serão analisados separadamente nas figuras 21, 22 e 24, onde estão presentes as principais variações dinâmicas utilizadas neste trabalho, no qual poderá ser feito toda análise do comportamento do sistema. Dessa forma podemos discutir fator por fator de cada etapa do processo de adaptação da quimiotaxia bacteriana.

\subsection{Atividade VS Concentração de Estímulos}

Para uma análise mais detalhada, vamos considerar inicialmente na figura 21 apenas a faixa inicial com o tempo de 0 a 20, na qual a concentração de ligante varia de 0.1 1. Neste primeiro momento, vamos analisar apenas a atividade (linha vermelha) e a concentração de ligantes (linha verde).

A figura 21 nos apresenta a visão completa do comportamento da atividade com o aumento da concentração de ligantes e receptores ligados. Podemos ver que o desenvolvimento da atividade está de acordo com o esperado para as condições iniciais do sistema. Fazendo a relação entre atividade e concentração de ligantes [L0] percebemos que com o aumento de $[L 0]$ variando de $10^{-1}$ para $10^{0}$, a atividade permanece praticamente no mesmo estado, mesmo tendo um leve decaimento em $t=10$, pois nessa faixa o valor de $[L 0]$ ainda é muito pequeno, o que não tem uma influência segnificativa no valor da média da atividade.

O ponto principal que devemos observar na figura 21 é a queda instantânea da atividade e o seu retorno lento ao nível adaptado a cada mudança instantânea na concentração de estímulos. Essa queda instantânea na atividade deve ser relacionada a variação da concentração, tendo em vista que receptores vazios e ativos serão rapidamente preenchidos devido a grande quantidade de estímulo, o que diminui sua 


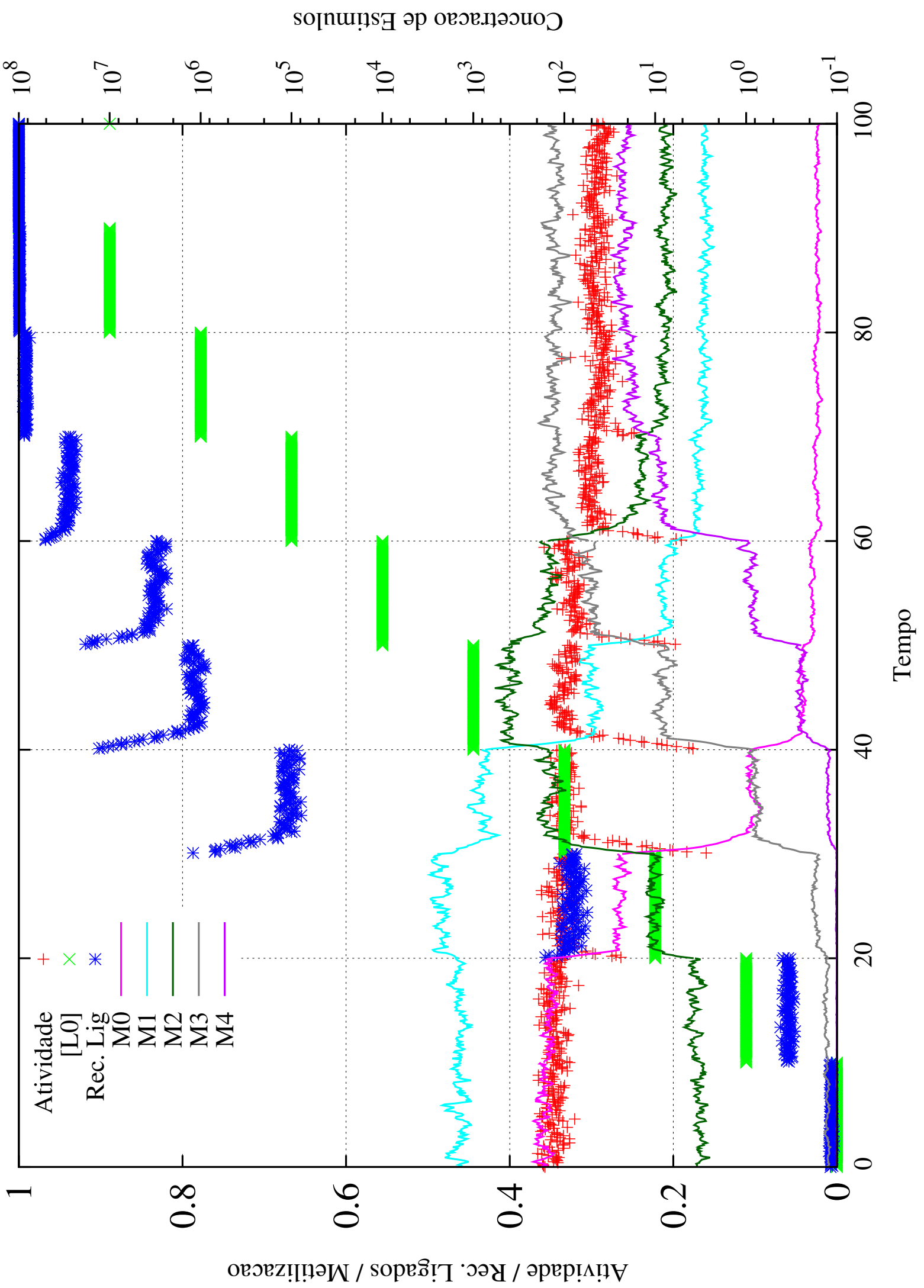

Figura 20 - Comportamento da atividade sob a influência da concentração de ligantes, dos receptores ligados (conectados) e dos grupos metílicos, onde a atividade se refere a média dos receptores ativos, o $[L 0]$ representa a concentração de estímulos externos, "Rec. Lig"é a média dos receptores ligados e $M 0, M 1, M 2, M 3, M 4$ são frações dos receptores com cada número de grupos metílicos. 


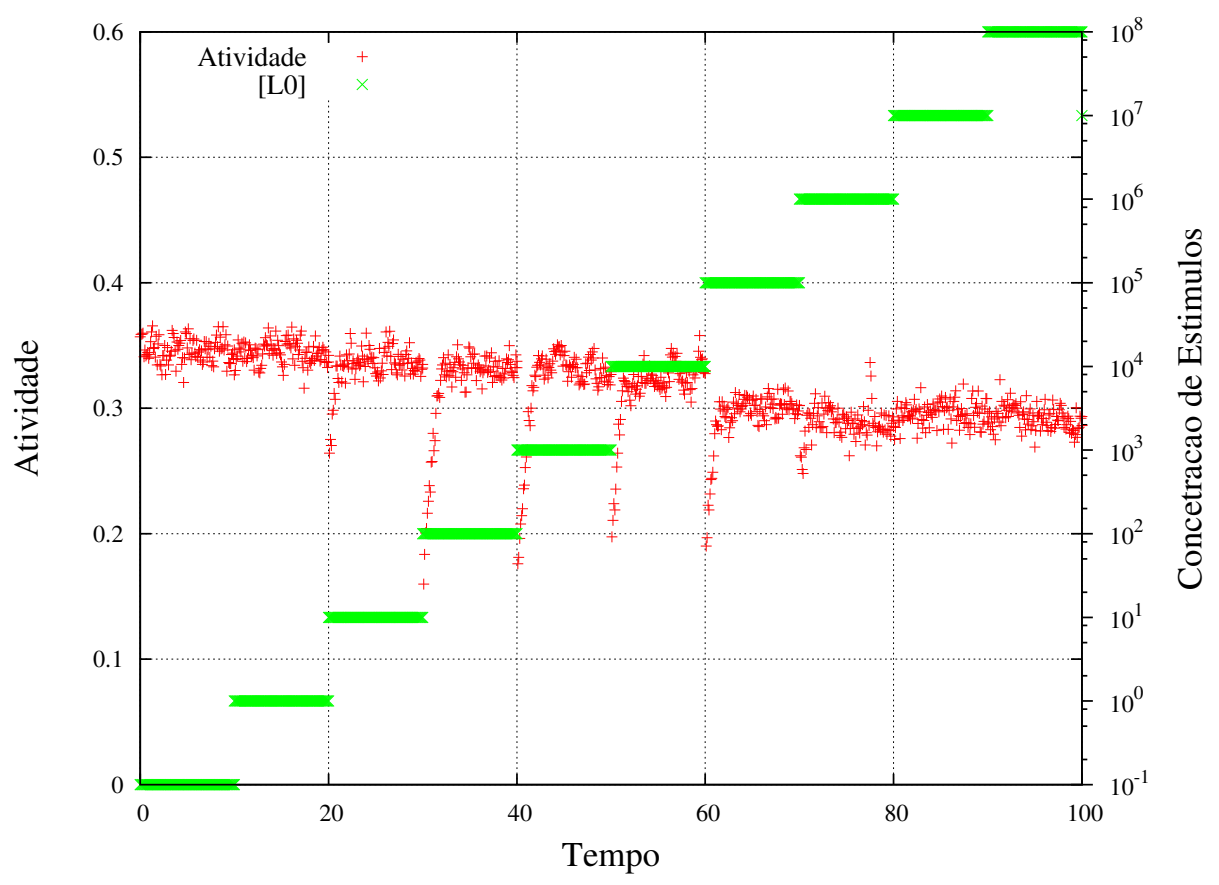

Figura 21 - Atividade dos receptores, Concentração de Estímulo.

atividade. Esse preenchimento rápido faz com que a atividade caia instantaneamente, diminuindo assim, a quantidade de CheY-P (CheY fosforizado), sendo responsável pela diminuição das guinadas da bactéria, conforme mencionado na seção 1.7. Este comportamento é o mais adequado, tendo em vista que a bactéria fará percursos mais longos antes de mudar de direção, desta forma, consumindo um número maior de nutrientes. Já o lento retorno ao nível adaptado é explicado pelo fato de o processo de metilização ser mais demorado, pois a metilização não pode ser feita em qualquer receptor, ou seja, o sistema tem que analisar o receptor que pode receber grupo metílico. Este comportamento pode ser percebido mais claramente na faixa entre $t=20$ a $t=60$ unidades de tempo. Nesse intervalo de tempo a concentração de estímulo aumenta de $10^{1}$ para $10^{5}$, com isso, podemos dizer que somente nessa faixa ocorre uma resposta quimiotática. Fora dessa faixa, o sistema não apresenta esse comportamento de queda na atividade por dois motivos: pela quantidade inicial de [LO] ser muito pequena e com isso não tem muita influência, ou por todos os receptores já estarem ocupados, e dessa maneira não apresenta mais a capacidade de resposta a adição de grupos metílicos.

Esse comportamento comprova que a atividade dos receptores depende da quantidade de ligantes, tendo em vista que quanto maior o número de estímulos, maior também será o numero de receptores conectados e, necessariamente, menor será a atividade do receptor. No entanto, conforme mencionado na seção 1.8 , a adaptação 


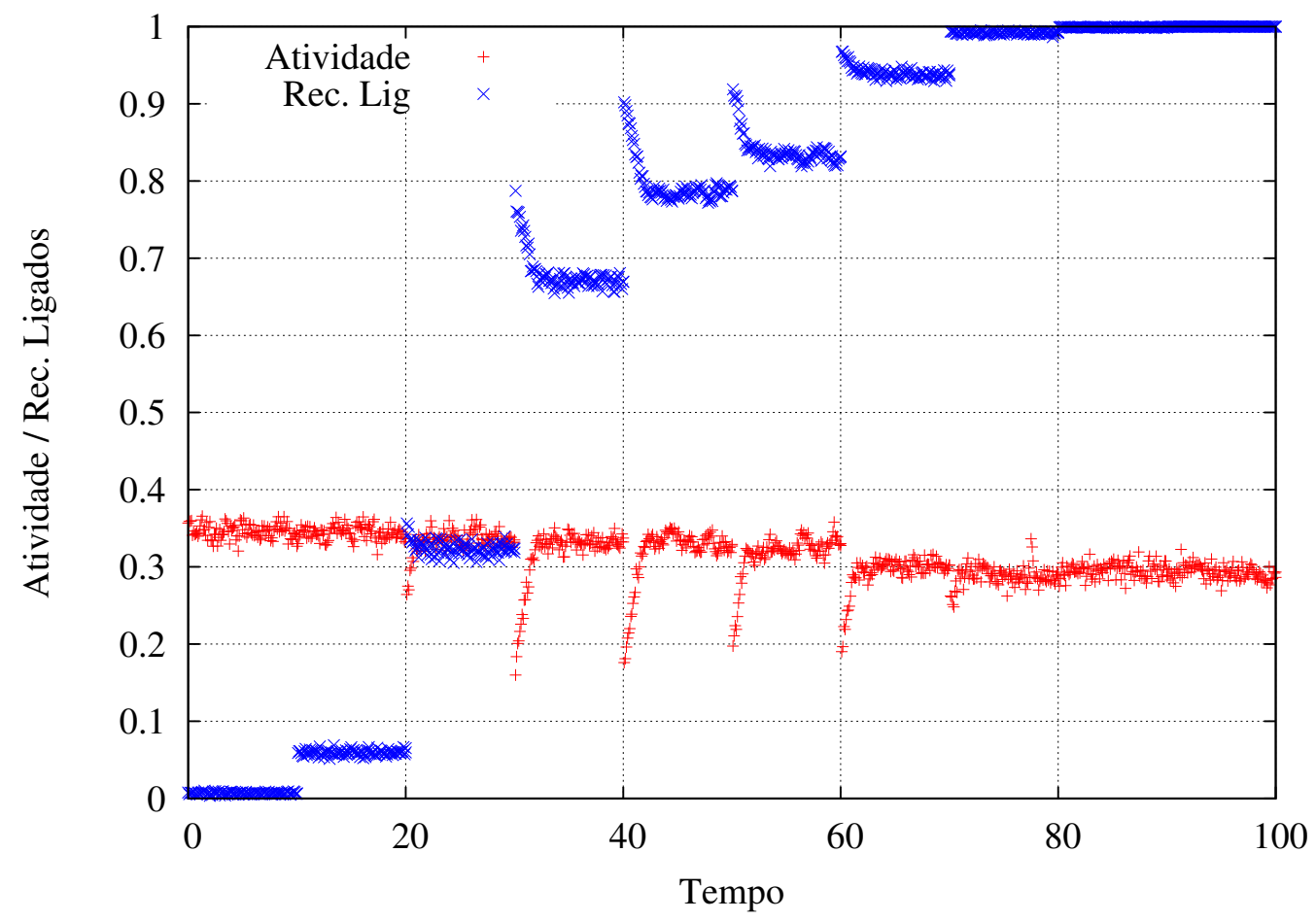

Figura 22 - Atividade dos receptores e receptores ligados aos ligantes.

independe da quantidade de estímulos no ambiente. Isso também pode ser visto na figura 21 nos intervalo de $[L 0]$ variando de $10^{1}$ a $10^{5}$, onde mesmo após o aumento significativo da concentração de estímulos e, consequentemente, do numero de receptores ligados, a atividade sempre se adapta, voltando a condição do estado estacionário. $\mathrm{O}$ que é compatível com a característica robusta do sistema da quimiotaxia da E. Coli.

\subsection{Atividade VS Receptores Ligados}

O gráfico 22, mostra a relação entre a atividade e os receptores ligados por ligantes. Nesse aspecto, devemos analisar a condição do aumento instantâneo dos receptores ligados, provocado pela mudança abrupta na concentração de estímulos, e sua queda gradativa, conforme a atividade aumenta. Para essa análise, devemos observar na figura os trechos onde ocorre um aumento significativo dos receptores ligados, que no caso do gráfico da figura 22 está presente visualmente em cinco pontos do processo $(t=20,30,40,50,60$ e 70$)$.

Nessa relação entre receptores ligados e atividade, dois aspectos podem ser descritos, um positivo e outro negativo. O positivo está relacionado ao ganho de sensibilidade do sistema, pois quanto maior a queda na atividade, após a mudança na 
concentração do estímulo, maior é a sensibilidade. Assim, como a atividade, a ligação dos receptores é um mecanismo rápido, instantâneo, se comparado com a dinâmica da metilização, por isso, no momento que os receptores se conectam aos ligantes a atividade decresce. Quanto maior a queda da atividade mais sensível é o sistema. O aspecto negativo é que se o aumento ocorrido inicialmente fosse mantido, o sistema não conseguiria ter uma boa resposta para o próximo aumento da concentração de estímulo. Isto pode ser observado no gráfico da figura 22, pois o maior valor obtido dos receptores ligados para uma concentração de estímulo é muito semelhante ao nível adaptado do próximo nível de concentração. Se isso ocorresse, seria uma evidência que o sistema não estaria tendo um bom ganho de sensibilidade. No entanto, a simulação demonstrou a situação ideal, onde, após um aumento rápido do número de receptores ocupados, ocorre uma diminuição gradativa, para que no próximo aumento de estímulo o sistema possa obter uma maior resposta possível.

Da mesma forma que o valor dos receptores conectados cresce instantâneamente, a atividade também decresce de forma instantânea, no entando seu retorno à atividade anterior é um processo mais demorado devido a metilização dos receptores ser um processo lento. Isso pode ser visto na curva mostrada na figura 23, que representa uma ampliação do comportamento da atividade entre o intervalo de $t=35$ a $t=50$. Com essa curva podemos visualizar melhor o que acontece ao redor do ponto de decaimento e retorno da atividade. Assim, percebemos que o sistema requer um intervalo de tempo maior para que a atividade retorne ao nível adaptado.

A sensibilidade está diretamente relacionada com a constante de dissociação $K$ que define a quantidade de receptores que não estão ligados e, consequentemente, a atividade do sistema. Assim, conforme a tabela 2, os receptores do tipo $q_{0}$, no estado inativo, precisam de apenas 18.1 de concentração para que $50 \%$ dos receptores sejam ligados, já para os receptores no estado ativo são necessários 53.995 de concentração para se ter $50 \%$ dos receptores preenchidos. A mesma discussão vale para os receptores $q_{1}$. Ou seja, em ambos os casos é bem mais difícil de se conectar quando o receptor esta no estado ativo. Esse conceito vai ao encontro com o conceito biológico que mostramos na seção 1.2, onde quanto menor o valor da constate $K$ maior será o número de receptores ligados e quanto maior seu valor, menor será o número de receptores ligados.

Desta forma, o sistema trabalha em conjunto, ou seja, quando os receptores 


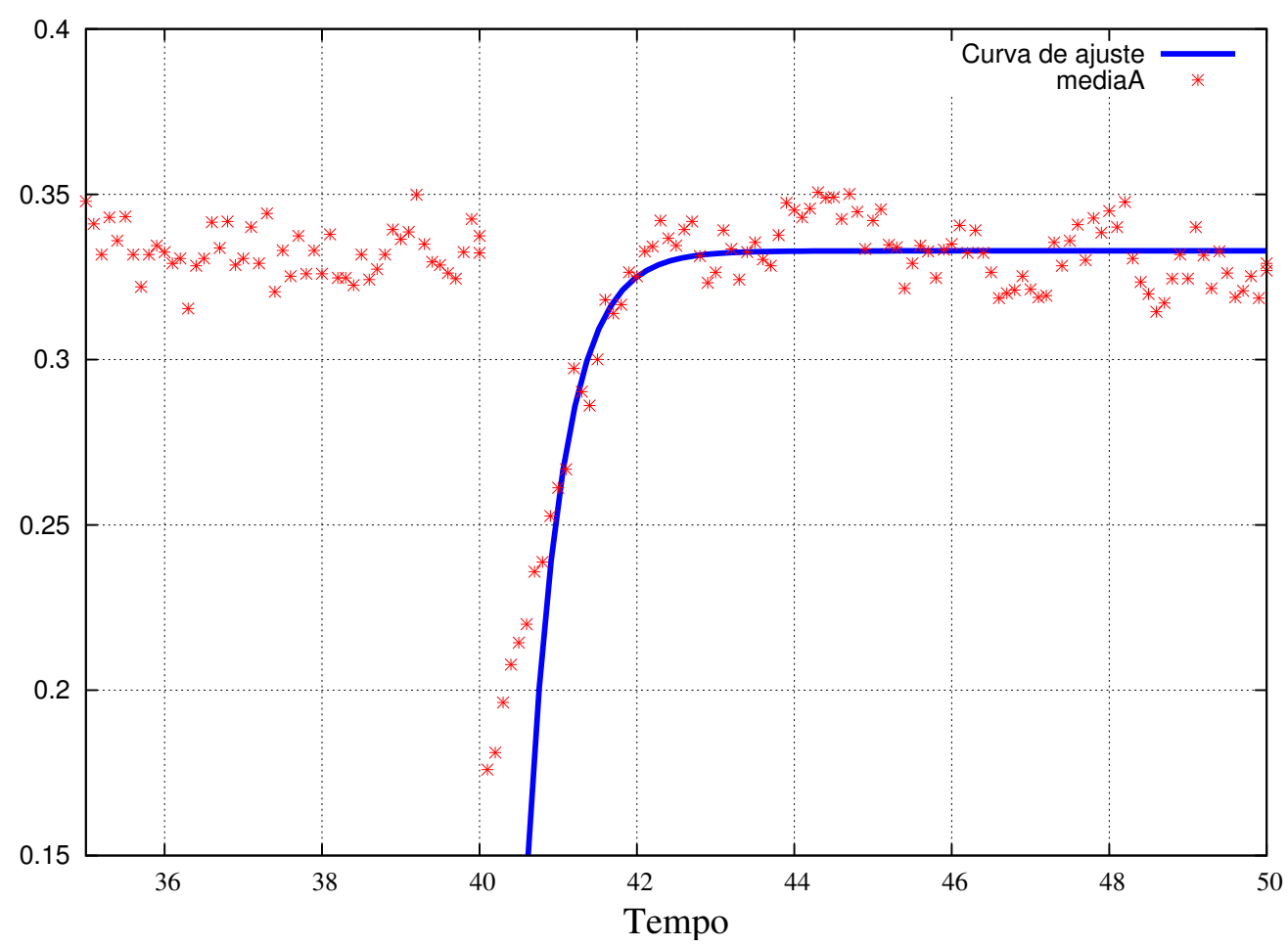

Figura 23 - Ampliação da figura 22 entre o intervalo $t=35$ a $t=50$.

se conectam aos ligantes a atividade diminui. Essa diminuição facilita a ligação dos receptores ligantes em um processo sinergético, pois quanto maior a inatividade maior o número de ligantes que se conectam aos receptores. Esse comportamento pode ser considerado como outro ponto positivo no sistema, pois é uma forma que ele encontrou de ter o melhor ganho possível de sensibilidade. Sendo essa, uma das características dos processos evolutivos das bactérias, onde a busca é pelo menor gasto de energia, com o propósito de obter sempre o maior ganho de sensibilidade.

O outro ponto a ser observado, é a diminuição dos receptores ligados à medida que a atividade aumenta, retornando ao nível adaptado. Isso ocorre porque, com a adição de grupos metílicos, os receptores voltam a ficar ativos e como já sabemos, receptores ativos tem uma maior dificuldade de se ligarem aos ligantes devido à constante de dissociação ser maior. Dessa forma eles tendem a expulsar os ligantes, fazendo com que a atividade aumente.

Em resumo, o mecanismo de ligação/atividade apresenta muitos méritos, destacandose a sinergia entre a atividade e a ligação de estímulos, seguida de uma lenta expulsão dos estímulos ligados, permitindo que os receptores estejam disponíveis para um posterior aumento de [LO]. 


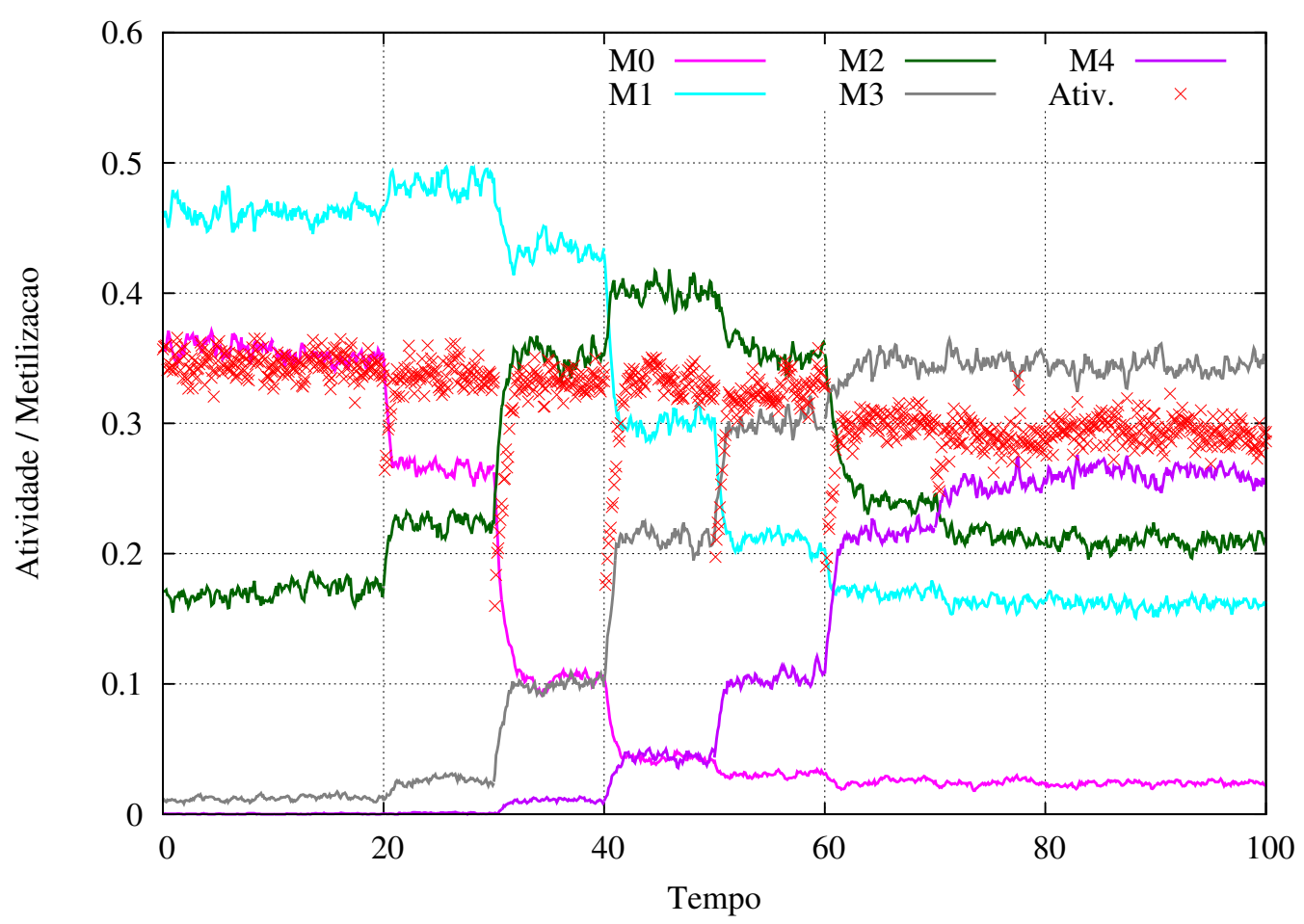

Figura 24 - Comparação entre a atividade por sítios de metilização.

\subsection{Atividade VS Metilização}

Vimos na seção 1.8 que a adição (CheR) e subtração (CheB) de grupos metílicos são os responsáveis pela adaptação do sistema, funcionando como reguladores desse processo. Sabemos que, quando a atividade está baixa, ocorre a adição de grupos metílicos e quando está alta, ocorre a subtração de grupos metílicos. No entanto, a forma como esses processos são acionados, ou até mesmo o limite que serve de parâmetro para esse acionamento ainda não é completamente entendida. Mesmo com essas dúvidas, acredita-se que esse processo é que controla a adaptação.

A figura 24 nos mostra como a população de receptores se distribui entre os 5 níveis de metilização $(M 0, M 1, M 2, M 3$ e $M 4)$ e a influência dessa distribuição no processo de adaptação. Um dos aspectos iniciais que podemos perceber é a variação gradativa na população de cada nível de metilização durante o processo de adaptação. Esse mecanismo é um fator fundamental para um maior aproveitamento do consumo de nutrientes pela bactéria, tendo em vista que a atividade e inatividade regulam a direção dos movimentos das bactérias.

Ainda no gráfico da figura 24 vemos que, inicialmente a população concentra-se nos sítios $M 0$ e $M 1$ e à medida que a concentração de estímulo é aumentada, mais re- 
ceptores são conectados aos ligantes, com isso ocorre uma maior distribuição em outros níveis de ocupação dos sítios metílicos tendo em vista que estamos obedecendo um modelo sequencial, conforme a figura 14. Podemos perceber também que no intervalo onde a adaptação é conseguida ( $t$ variando de 20 a 60) o nível de $M 0$ começa a diminuir e os outros sítios metílicos tendem a aumentar, com exceção de M1 que também têm uma queda. Essa descrição ficará mais clara ao observamos a figura 25.

A quantidade de sítios de metilização existentes nos receptores está diretamente relacionada com a capacidade de adaptação da bactéria. Sabendo disso, podemos verificar na figura 24 que o processo de adaptação pode ser alcançado quando os grupos metílicos dos extremos, neste caso os $M 0$ e $M 4$, estão em um nível baixo. Isso pode ser visto no intervalo de $t$ variando entre 0 e 50, onde a adaptação para a atividade anterior é, de certa forma, conservada, existindo apenas uma pequena queda devido a perda natural do sistema.

No entanto, quando M4 começa a ficar mais cheio, percebemos que o sistema tende a perder a capacidade de adaptação. Isso coloca o sítio $M 4$ como um regulador da adaptação, pois pelo modelo sequencial, quando o M4 é muito populado, a metilização dos receptores chegaram ao seu máximo, não tendo mais um caráter de regulação. Isto porque, quanto maior o número de receptores totalmente metilizados menor será a possibilidade de se alcançar a atividade anterior. Tendo em vista que agora temos menos receptores com capacidade de ganhar grupos metílicos e outros receptores que só podem perder grupos metílicos o que torna-os menos ativo.

A condição que assegura esse comportamento foi descrita na seção 2.4 pela equação 2.59, onde definimos que para acontecer a perfeita adaptação a população de M0, no estado ativo, deve ser muito pequena, ou seja, $M 0 \ll 1$. O mesmo entendimento se aplica a $M 4$, no estado inativo, ou seja, $M 4 \ll 1$. Para uma análise melhor das condições de adaptação perfeita, calculamos a atividade média do receptor no estado metílico $M 0$, conforme abaixo:

Usando os valores da tabela 2 e considerando a equação $H_{q \vec{m} l a}=\mu_{q a} l+\left(E_{q m}^{M}+\right.$ $\left.E_{q}^{C}\right) a$ para uma população de receptores não ligado e com estado do sítio metílico M0 temos a seguinte distribuição:

$$
\langle a\rangle_{m=0}=\frac{e^{-H_{q, 0,1}}}{e^{-H_{q, 0,0}}+e^{-H_{q, 0,1}}}
$$


considerando a dependência com os sítios metílicos $E_{q m}^{M}$ temos,

$$
E_{q m}^{M}=-\alpha\left(m_{q 0}\right)=3
$$

agora, considerando a interação com os receptores vizinhos,

$$
E_{q}^{C}=\frac{1}{2} \sum_{j n . n . i} C_{q_{i} q_{j}}\left(a_{i}-0.5\right)\left(a_{j}-0.5\right)
$$

considerando os receptores vizinhos podemos encontrar os valores extremos de $E_{q}^{C}$ como:

$$
-\frac{1}{2}<E_{q}^{C}<\frac{1}{2}
$$

Usando estas relações na equação 4.1 podemos encontrar a atividade média "máxima" para o receptor de sítio metílico M0 e não ligado,

$$
\begin{aligned}
\langle a\rangle_{m=0} & =\frac{e^{-H_{q, m=0,0,1}}}{e^{-H_{q, m=0,0,0}+e^{-H_{q, m=0,0,1}}}} \\
& =\frac{e^{-\left(E_{q}^{M}+E_{q}^{C}\right)}}{1+e^{-\left(E_{q}^{M}+E_{q}^{C}\right)}} \\
& =\frac{e^{-3.5}}{1+e^{-3.5}} \\
& =0.029
\end{aligned}
$$

Assim, podemos ver que os parâmetros dados na tabela 2 fazem com que a condição 2.59 seja obedecida, pois vemos que a quantidade de receptores ativo no estado M0 é muito baixa.

Uma forma melhor de visualizar esse movimento da população em cada sítio metílico é através dos histogramas mostrados na figura 25. Os dados para essa análise foram retirados do estado estacionário de cada receptor imediatamente antes da mudança de concentração, sendo uma média dos últimos 20 pontos. Dessa forma, podemos perceber que conforme M4 aumenta a adaptação começa a ter problemas.

Pelos histogramas mostrado na figura 25 fica mais claro o que discutimos anteriormente. Podemos ver que no início do processo pouco se altera na quantidade da população de cada sítio metílico, pois como vimos, nesse momento, a quantidade de receptores ligados ainda não é grande o suficiente para produzir uma queda na atividade. No entanto, a mudança mais perceptível está localizada entre $[L 0]=10^{5} \mathrm{e}$ $[L 0]=10^{6}$, é nessa faixa de concentração de estímulos que percebemos um aumento 


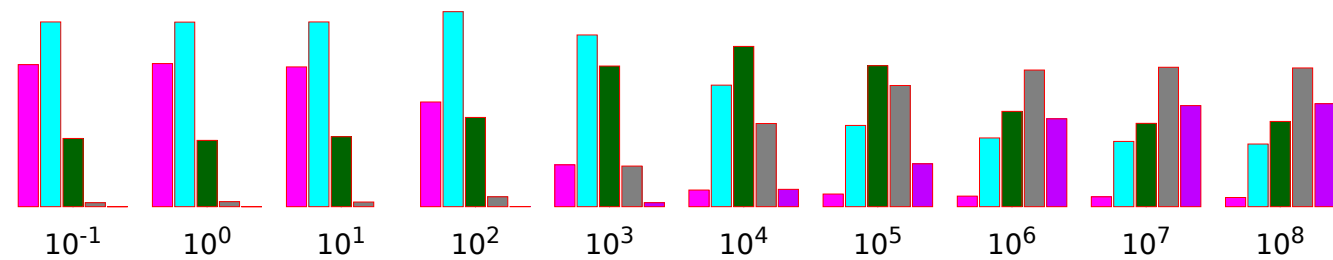

Figura 25 - Distribuição dos níveis após a adaptação, obtidos dos valores médios dos 20 últimos pontos antes de cada mudança de concentração da figura 20, da esquerda para a direita, as colunas de cada conjunto representam a ocupação dos receptores $M 0, M 1, M 2, M 3$ e $M 4$, com a concentração de estímulo no intervalo de $10^{-1}$ a $10^{8}$

considerável na população de $M 4$ e consequentemente, a não adaptação. Pela figura 24, vemos que quando $[L 0]>10^{6}$ o sistema já está estabilizado e adaptado para todos os receptores.

O motivo pelo qual M0 inicialmente se encontra alto na figura 25 é devido as condições iniciais da simulação. No entanto, podemos perceber que à medida que ocorre um aumento na quantidade de estímulos, mais ligantes se conectam nos receptores. Dessa forma, M0 começa a decair, conforme esperado, pois como vimos, os extremos devem ser menos metilizados para que ocorra a adaptação.

Esse aspecto fica mais claro nas figuras 26 e 27, onde aumentamos em uma unidade o valor de $m_{q 0}$ (imagem 26a) e em duas unidades (imagem 27a) nos parâmetros iniciais (tabela 2). É possível perceber a perda da adaptação logo após a parte inicial do sistema, quando $M 4$ começa a aumentar.

A função do $m_{q 0}$, na dinâmica da simulação, é promover um deslocamento da esquerda para direita na inicialização da metilização. Por esta razão vemos que quanto maior o valor de $m_{q 0}$ maior será a diferença na inicialização da metilização de cada receptor, tendo em vista que ele está diretamente ligado à dependência com os grupos metílicos $E_{q m}^{M}$, conforme mostrado na equação 2.33 da seção 2.1.

\subsection{Efeitos do número de grupos metílicos}

Outra forma de se mostrar a relação de dependência entre a adaptação e os sítios metílicos é alterando a sua quantidade. Ao invés de 4 sítios da E. Coli, simulamos receptores com 3 e 6 sítios e analisamos o comportamento com essas alterações. Como resultado, podemos perceber pela figura 28 que com 3 sítios o sistema não conseguiria 


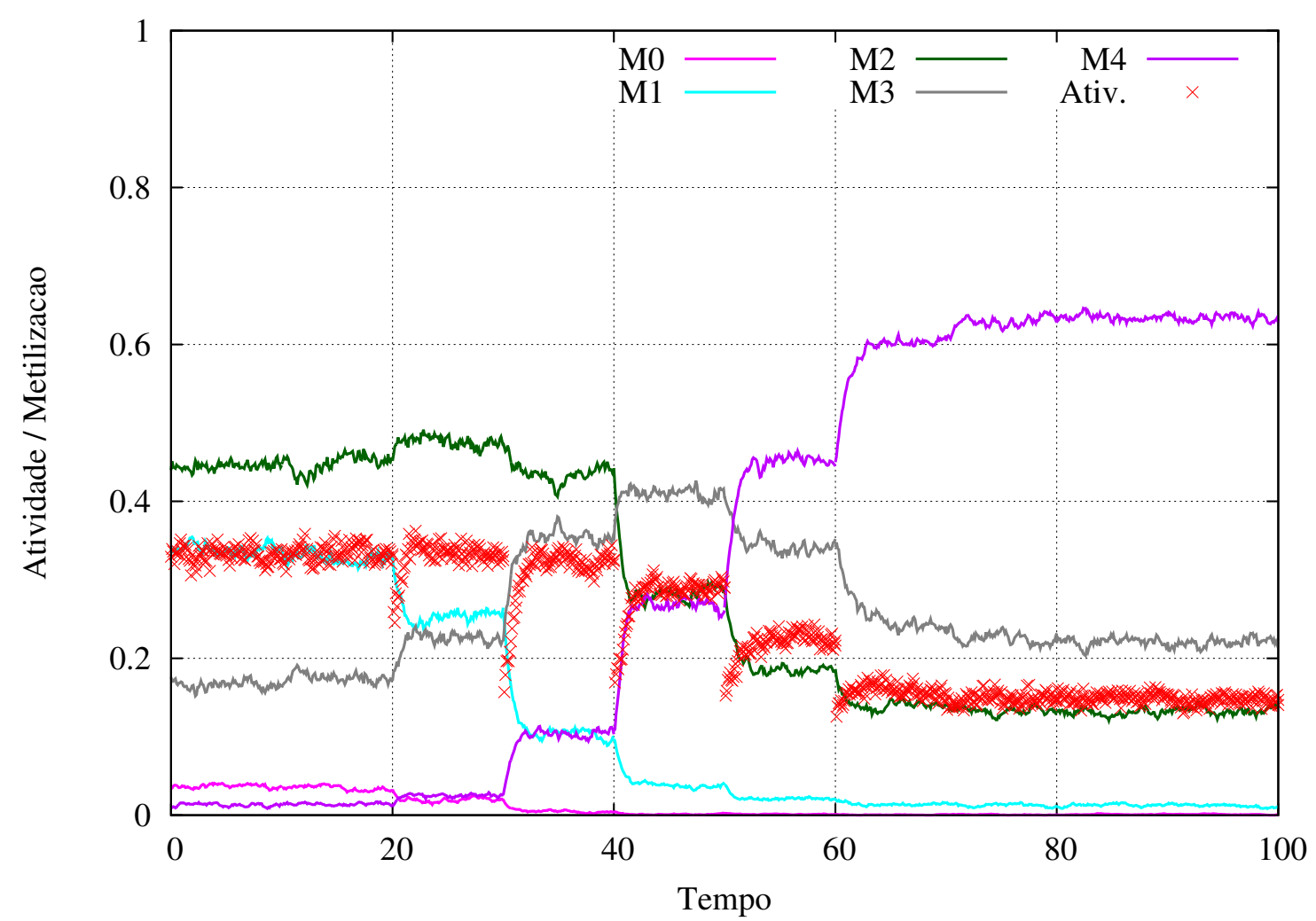

(a)

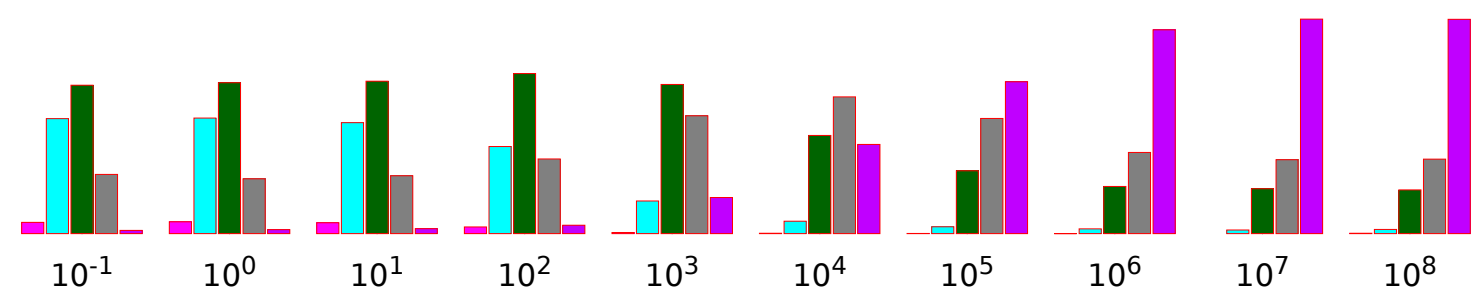

(b)

Figura 26 - Comportamento do sistema com $m_{0}=2$ : a) gráfico com a atividade e a metilização; b) distribuição da população de $M 0, M 1, M 2, M 3$ e $M 4$, entre o intervalo de concentração de estímulo de $10^{-1}$ a $10^{8}$.

se adaptar com $[L 0]>0$ o que seria desvantajoso, a figura 28a representa o gráfico geral e a figura 28 b nos dá a ocupação da população de cada grupo metílico.

Para receptores com 6 sítios (figura 29) percebemos que a atividade volta totalmente ao seu estado inicial para qualquer valor de [L0], o que tornaria a adaptação perfeita em todo o intervalo de concentração estudado. A figura 29a representa o gráfico geral e 29b nos dá a ideia da ocupação da população de cada grupo metílico. Nesta simulação, percebemos que a adaptação é totalmente alcançada no sistema, mesmo com o aumento do nível de metilização do $M 4$.

Dessa forma, fazendo uma comparação entre os gráficos das figuras 20, que 


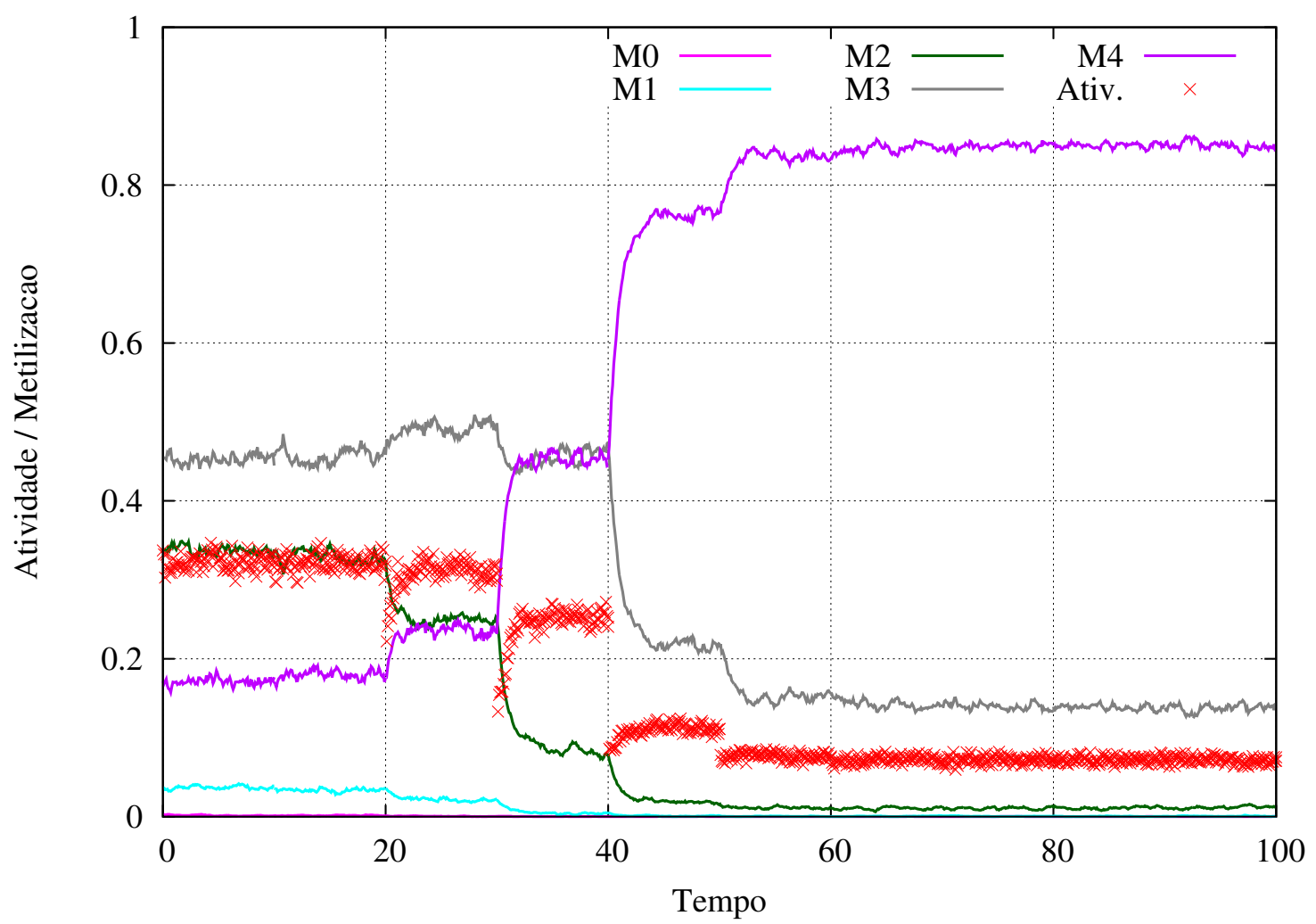

(a)

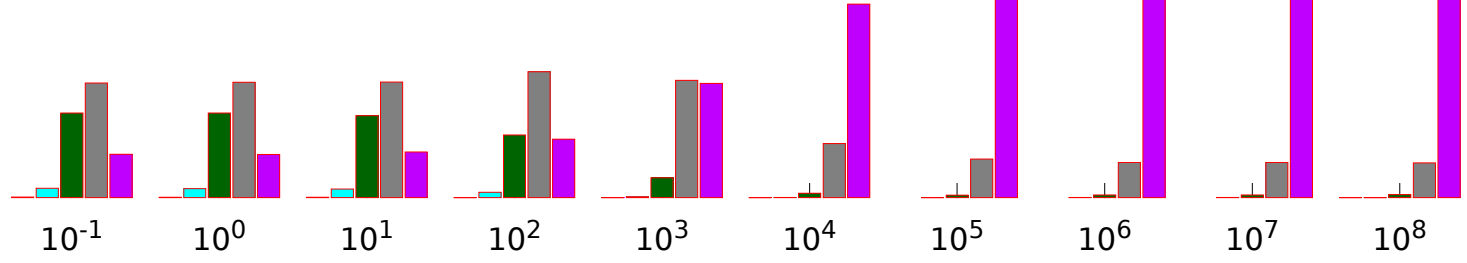

(b)

Figura 27 - Comportamento do sistema com $m_{0}=3$ : a) gráfico com a atividade e a metilização; b) distribuição da população de $M 0, M 1, M 2, M 3$ e $M 4$, entre o intervalo de concentração de estímulo de $10^{-1}$ a $10^{8}$.

representa o sistema com 4 sítios metílicos e o gráfico da figura 29 que representa o sistema com 6 sítios, podemos perceber que não existe um grande ganho de resposta à adaptação, quando aumentamos o número de sítios metílicos no sistema. Assim, a formação dos receptores com 4 sítios metílicos foi a melhor escolha biológica para o sistema, pois, mesmo tendo pequenas flutuações no retorno à atividade anterior, o sistema têm um comportamento satisfatório mesmo não apresentando a adaptação perfeita.

As simulações, utilizando o modelo sequencial, mostraram que mesmo alterando os parâmetros o sistema sempre tende a adaptação no final do processo, tendo em vista 


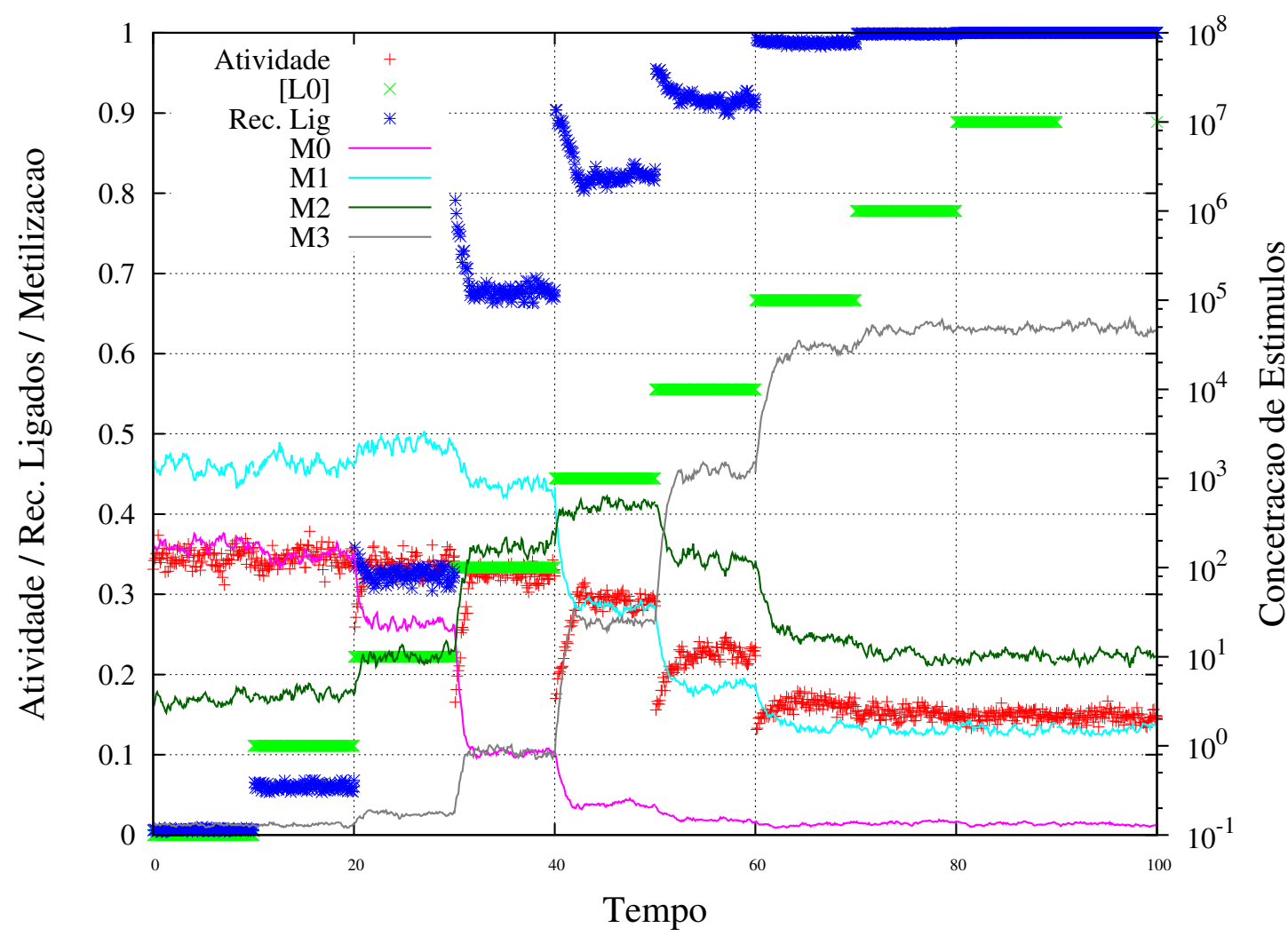

(a)

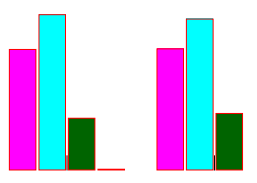

$10^{-1} \quad 10^{0}$

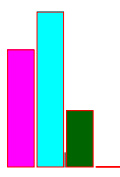

$10^{1}$

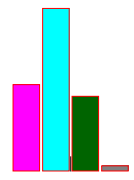

$10^{2}$

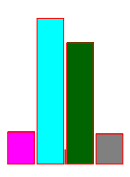

$10^{3}$

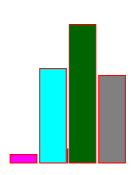

$10^{4}$

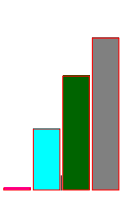

$10^{5}$

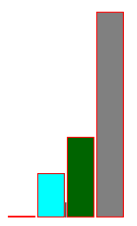

$10^{6}$

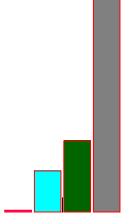

$10^{7}$

(b)

Figura 28 - Comportamento do sistema com 3 sítios de metilização: a) Refere-se ao gráfico geral com todas as grandezas $a,[L 0]$, Rec.lig e sítios metílicos M0, M1, M2, M3; b) Histograma com a ocupação das populações de cada sítios metílicos. 


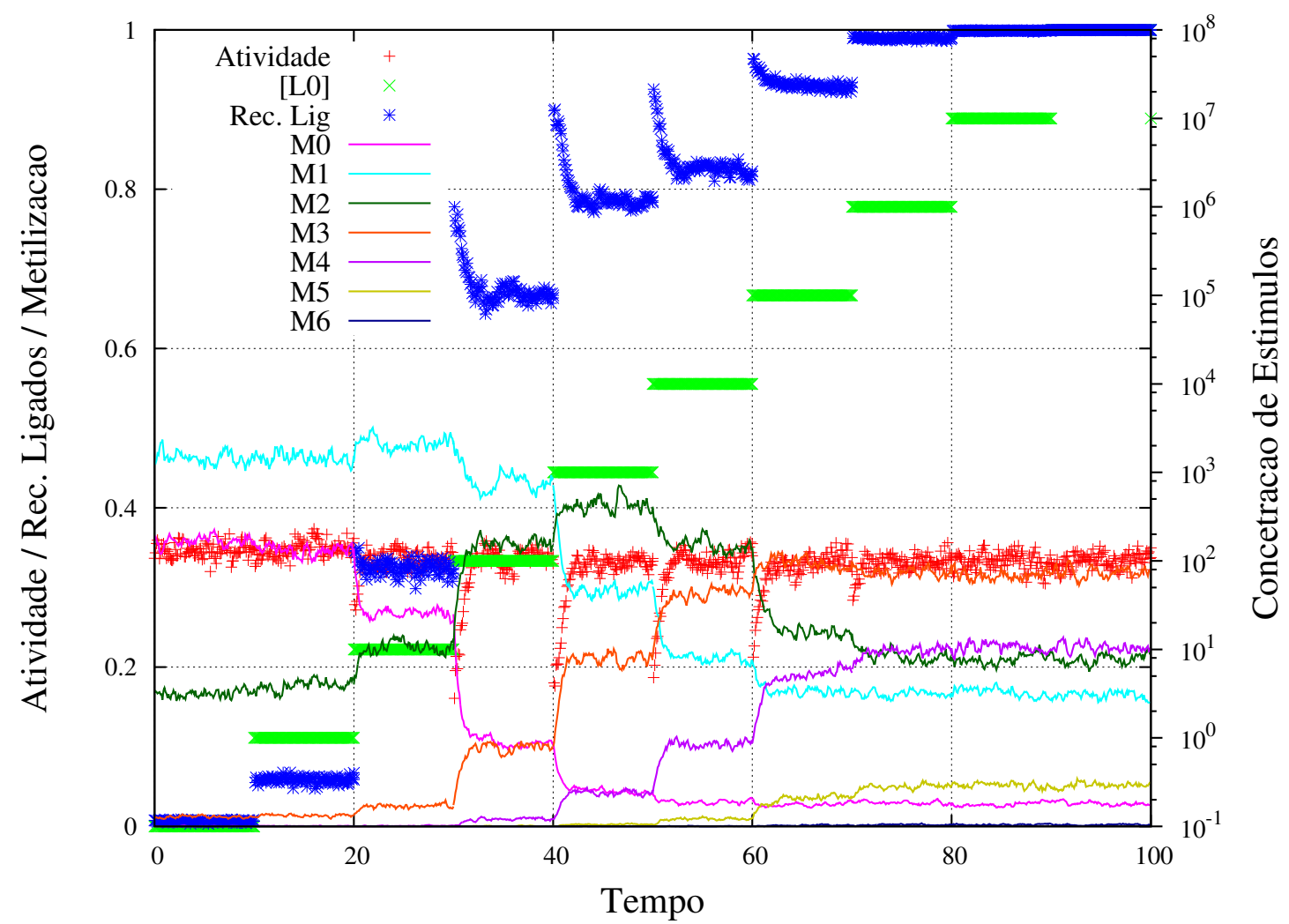

(a)

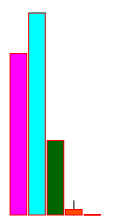

$10^{-1}$

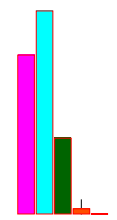

$10^{0}$

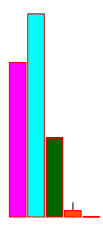

$10^{1}$

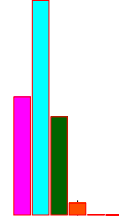

$10^{2}$

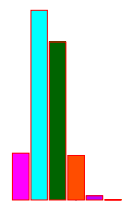

$10^{3}$

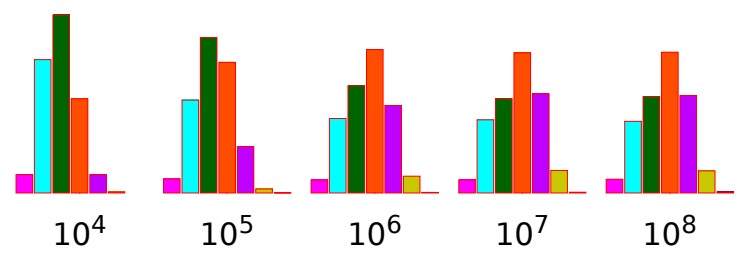

(b)

Figura 29 - Comportamento do sistema com 6 sítios de metilização: a) Refere-se ao gráfico geral com todas as grandezas $a,[L 0]$, Rec.lig e sítios metílicos M0, M1, M2, M3, M4, M5, M6; b) Histograma com a ocupação das populações dos sítios metílicos. 
que todos os receptores estão conectados com ligante.

Portanto, conforme esperado, os extremos M0 e M6 estão com uma população bem baixa e o sistema está conseguindo se adaptar perfeitamente. Essa simulação foi feita tanto para $n=64$ como para $n=100$, onde $n$ é o número de receptores.

\subsection{Modelo Não-Sequencial}

Outro ponto que podemos mostrar nesse trabalho é a simulação para um modelo não sequencial (figura 30). Ela têm todas as grandezas e os grupos metílicos do sistema usado no modelo sequencial. Desta forma, podemos perceber, neste modelo não-sequencial, a existência da mesma dinâmica reservada para o modelo sequencial, como por exemplo, o aumento da quantidade de concentração de estímulos, a ligação dos receptores aos ligantes, a queda instantânea da atividade e a ocupação dos sítios metílicos (M0,M1,M2, M3,M4). No entanto, vemos que não ocorre a adaptação da atividade.

Nesse modelo foi imposto que o preenchimento dos sítios metílicos não seguem uma sequência. Pelo modelo não-sequencial o preenchimento dos sítios obedece o que foi mostrado na figura 15, no qual temos 16 possibilidades, ao invés de 5 do modelo sequencial. Pela figura podemos perceber algumas semelhanças, mas também uma divergência muito importante com o modelo sequencial apresentado anteriormente. A principal diferença surge da impossibilidade de obter uma equação que define a adaptação perfeita, equação 2.62, assim como as condições dadas pela equação 2.59.

Como semelhanças podemos citar o comportamento inicial, onde, igualmente o modelo sequencial, não existem mudanças expressivas, tendo em vista que, no início, pela quantidade de estímulos, poucos receptores estão conectados aos ligantes. Outro fato semelhante é que a relação dos receptores com os ligantes é feito de forma quase instantânea. Por fim, podemos notar que o final do processo todo o sistema tende a se adaptar devido todos os receptores estarem ligado aos ligantes.

Importa para o sistema a queda da atividade e o seu retorno gradual para o valor anterior, o que em nenhum momento foi percebido, conforme mostrado na figura 30a. Podemos perceber através da figura 30b que mesmo com a população dos grupos metílicos M0 e M4 (considerados como reguladores da adaptação) sendo relativamente 


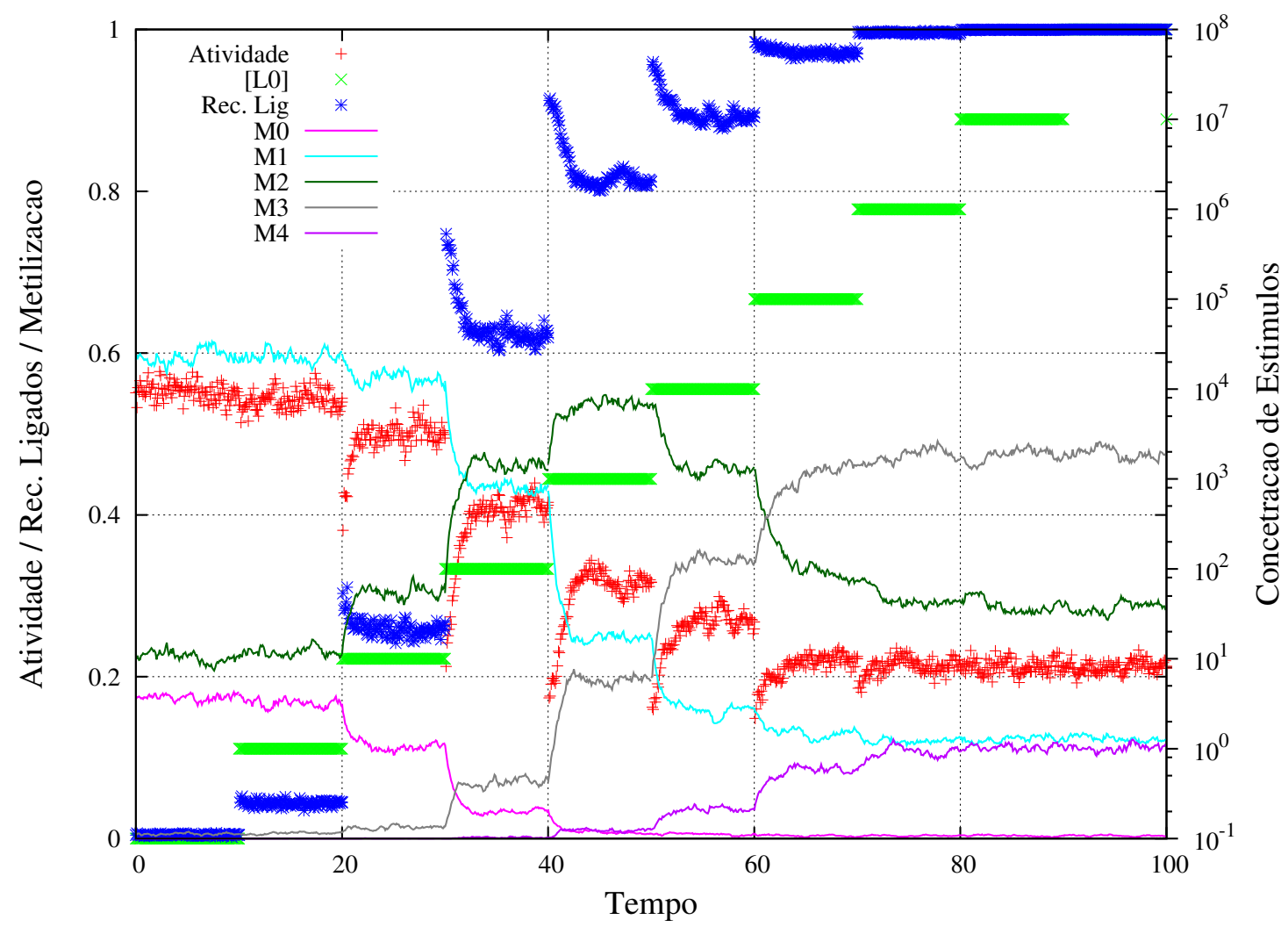

(a)

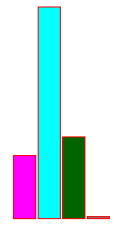

$10^{-1}$

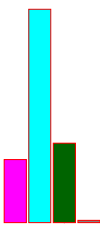

$10^{0}$

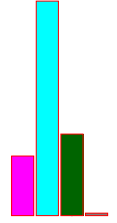

$10^{1}$

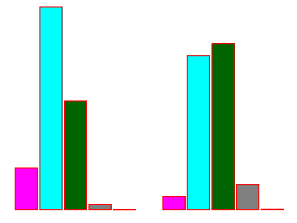

$10^{2}$

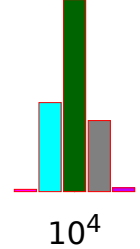

(b)

Figura 30 - Demonstração do sistema não-sequencial: a) Refere-se ao gráfico geral com todas as grandezas b) Histograma com a ocupação das populações de cada sítio metílico.

baixa, o sistema não se adapta. A não-adaptação pode ser percebida de imediato, logo quando uma quantidade maior de ligantes se conecta aos receptores, como por exemplo uma concentração de $[L 0]=10^{4}$. Isto pode ser visto a cada aumento de concentração de estímulos. Portanto, demonstrando que pelo modelo não-sequencial a bactéria não conseguiria a perfeita adaptação. Resumidamente a principal diferença quando comparado o modelo sequencial com o não-sequencial é a não-adaptação. 

Parte III

Conclusão 



\section{Conclusão}

É conhecido (seção 2.3) a analogia entre os receptores da bactéria E.Coli com o modelo de ising para objetos ferromagnéticos, no qual, para o cálculo da energia do sistema é levado em conta a força de interação dos spins dos elétrons. No caso da bactéria E. Coli, a interação acontece entre receptores, independentes das afinidades para determinados estímulos, isso porque a E. Coli possui cinco diferentes tipos de receptores, cada um com uma afinidade para determinado tipo de atraente, sendo os

tipos Aspartato e Serina os mais abundantes. Desta forma, a ligação de um tipo de estímulo afeta todos os receptores. Este entendimento foi primordial para o cálculo da energia individual de cada receptor e com isso a energia total do sistema, onde, para este cálculo, além da força de interação é também considerado a energia livre e a conexão do receptor com os ligantes.

O foco principal deste trabalho girou em torno da adaptação perfeita, que consiste basicamente no restabelecimento do nível de atividade após um aumento na concentração do ligante. Para este estudo, utilizamos como instrumento de demonstração simulações Monte Carlo com algoritmo de Metrópolis. Usamos parâmetros retirados de estudos anteriores. Com a simulação fomos capazes de analisar os resultados obtidos e indicar comportamentos que condizem com a realidade do sistema. As simulações foram feitas obedecendo os modelos sequencial e não-sequencial, que possuem como diferença básica a ordem aleatória de metilização/desmetilização, sendo que no modelo não-sequencial existem mais possibilidades de preenchimento dos sítios, 16 no total.

Os produtos das nossas simulações foram gráficos que serviram para visualizar individualmente cada ponto principal da quimiotaxia, tais como atividade, concentração de ligantes (estímulos), e população dos sítios metílicos. Os resultados em forma de gráfico também serviram para que pudéssemos provar que adaptação somente pode ser conseguida quando obedecemos ao modelo de metilização sequencial.

Nos gráficos analisados, compreendemos melhor o comportamento que a bactéria tem quando está em um ambiente onde a concentração de estímulo aumenta. Essa alteração na concentração de estímulos está diretamente relacionada com a quantidadede receptores que se ligam aos ligantes (estímulos) e também com o restabelecimento 
da atividade anterior. As simulações também ajudaram a comprovar que a quantidade de quatro sítios metílicos é a que mais se adequa para o sistema real. Para comprovarmos isso, realizamos simulações com três e seis sítios. O número menor de sítios não deixou que o sistema se adaptasse em nenhum momento, ao contrário do que o número maior de sítios fez à simulação, pois obtivemos a perfeita adaptação. Contudo, percebemos que a formação com quatro sítios o sistema apresenta uma pequena perda na adaptação durante o processo, o que pode ser aceitável no ponto de vista biológico. Assim, justifica-se a escolha de quatro sítios feita pela natureza, pois traz uma leve flutuação na adaptação o que é o esperado para um processo biológico que depende de fatores externos.

Como a proposta deste trabalho é baseada na sequência da metilização da $E$. Coli fizemos também a simulação obedecendo o modelo não-sequencial e conseguimos evidenciar que nesse modelo o sistema não se adapta. Para esta simulação obedecemos os mesmos parâmetros utilizados no modelo sequencial.

Portanto, este trabalho contribuiu para uma melhor compreenção da quimiotaxia bacteriana, além de confirmar a importância que as simulações tem nos dias atuais, no auxílio a diversas áreas de educação. Como proposta para trabalhos futuros podemos citar a implantação do modelo não-sequencial junto com a verificação dos parâmetros necessários para que este modelo consiga estabelecer a adaptação perfeita. Para tanto varreremos o espaço de parâmetros para verificar se os resultados obtidos são, ou não, uma particularidade do conjunto de parâmetros utilizados. Dessa forma, pretendemos demonstrar a importância da metilização sequencial e da suficiência de 4 sítios metílicos de ligação nos receptores. 


\section{Referências}

1 TU, Y. Quantitative modeling of bacterial chemotaxis: Signal amplification and accurate adaptation. Annual Review of Biophysics, Annual Review of Biophysics, v. 42, p. 337-359, fev 2013. Citado 5 vezes nas páginas xi, 1, 26, 27 e 30.

2 VIEIRA, R. Fundamentos de Bioquímica: textos didáticos. Belém do Pará: Universidade Federal do Pará, 2003. Citado na página 5.

3 SANTOS, C. F. Bioquímica Metabólica. In. GUERRA. R. A. (Org). Ciências Biológicas. $3^{\circ}$ ed.. ed. João Pessoa: Editora Univesitária UFPB, 2011. Citado na página 5.

4 CORSINO, J. Bioquímica. Campo Grande: UFMS, 2009. Citado 2 vezes nas páginas xi e 6.

5 NELSON, D. L.; COX, M. Princípios de Bioquímica. $3^{\circ}$ ed.. ed. São Paulo: Springer, 2002. Citado 2 vezes nas páginas 6 e 7.

6 JUNIOR, W. E. Proteinas: Hidrolise, precipitação e um tema para o ensino de química. Química Nova Escola, Química Nova Escola, v. 24, nov 2006. Citado na página 6.

7 EISENBACH, M. Chemotaxis. London: Imperial College Press - ICP, 2004. Citado 4 vezes nas páginas $8,11,20$ e 24 .

8 MURRAY, J. D. Mathematical Biology: I. An Introduction. Third edition. WashingtonEUA: [s.n.], 2002. Citado na página 9.

9 BREN, A.; EISENBACH, M. How signals are heard during bacterial chemotaxis: protein-protein interactions in sensory signal propagation. Journal of Bacteriology, Nature, v. 182, p. 6865-6873, dec 2000. Citado 4 vezes nas páginas xi, 10, 19 e 20.

10 BERG, H. Motile behavior of bacteria. physics Today, physics Today, p. 24-29, 2000. Citado na página 10.

11 WIKIPEDIA. Chemotaxis - Wikipedia, The Free Encyclopedia. 2014. [Online; accessed 25-September-2014]. Disponível em: $<$ http://en.wikipedia.org/w/index.php?title= Chemotaxis\&oldid=622954526>. Citado 3 vezes nas páginas xi, 10 e 14.

12 EISENBACH, M. Encyclopedia of life sciences. Nature Publishing Group, Nature Publishing Group, 2001. Citado 7 vezes nas páginas xi, xv, 11, 12, 14, 15 e 16.

13 SOURJIK, V. Receptor clustering and signal processing in e. coli chemotaxis. TRENDS in Microbiology, TRENDS in Microbiology, v. 12, n. 12, dec 2004. Citado 3 vezes nas páginas 12,18 e 21.

14 EISENBACH, M.; R., C. S. Bacterial chemotaxis: Unsolved mystery of the flagelar switch. Current Biology, Current Biology, v. 8, p. 444-446, 1998. Citado na página 13.

15 INSALL, R. H. Understending eukaryotic chemotaxis: a pseudopod-centred view. Nature Reviews Molecular Cell Biology, Nature Reviews Molecular Cell Biology, v. 11, p. 453-458, 2010. Citado na página 14. 
16 GUZMAN, M. Técnicas de otimização baseadas em quimiotaxia de bactérias. Dissertação (Doutorado) - Escola de Engenharia de São Carlos da Universidade de São Paulo, 2009. Citado 4 vezes nas páginas xi, 15, 17 e 18.

17 KUDO, S.; MAGARIYAMA, Y.; AIZAWA, S. Abrupt change in flagellar rotation observed by laser dark-field microscopys. Nature, Nature, v. 346, p. 677-680, 1990. Citado na página 17.

18 BAKER, M. D.; M., W. P.; B, S. J. Signal transduction in bacterial chemotaxis. BioEssay, BioEssay, v. 28, 2005. Citado 2 vezes nas páginas 20 e 22.

19 ALON, U. et al. Roburtness in bacterial chemotaxis. Nature, Nature, v. 397, jan 1999. Disponível em: <http:/ /www.nature.com>. Citado 2 vezes nas páginas 22 e 23.

20 MORTON-FIRTH, C. J.; SIMIZU, T. S.; BRAYD. Afree-energy-based stochastic simulation of the tar receptor complex. J. Mol. Biol, J. Mol. Biol, p. 1059-1074, 1999. Citado 3 vezes nas páginas xi, 22 e 23.

21 LAN, G. et al. Adapt locally and act globally: strategy to maintain high chemoreceptor sensitivity in complex environments. Mol. Syst. Biol., Mol. Syst. Biol., 2011. Citado 7 vezes nas páginas xi, 24, 27, 35, 37, 42 e 43.

22 GUYTON, A. C.; HALL, J. E. Fisiologia Médica. Rio de Janeiro: Guanabara Koogan, 2002. 973 p. Citado na página 24.

23 ENDRES, R. G.; J., F. J.; S, W. N. Chemotaxis receptor complex: From signaling to assembly. Plos Computation Biology, Plos Computation Biology, v. 3, p. 152-173, dec 2010. Citado na página 25.

24 MELLO, B. A.; TU, Y. Effects of adaptation in maintaining high sensitivity over a wide range of backgrounds for e. coli chemotaxis. Biophysical Journal, Biophysical Journal, p. 2329-37, 2007. Citado 3 vezes nas páginas 25, 26 e 42.

25 MELLO, B. A.; TU, Y. An allosteric model for heterogeneous receptor complexes: understanding bacterial chemotaxis response to multiple stimuli. Proc. Natl. Acad. Sci, Proc. Natl. Acad. Sci, p. 17354-59, 2005. Citado 2 vezes nas páginas 26 e 37.

26 BRAY, D.; LEVIN, M. D.; MORTON-FIRTH, C. J. Receptor clustering as a cellular mechanism to control sensitivity. Nature, Nature, v. 393, 1998. Citado na página 27.

27 SHI, Y.; DUKE, T. Cooperative model of bacterial sensing. The American Physical Society, The American Physical Society, v. 58, p. 6399-6406, 1998. Citado na página 27.

28 MELLO, B. A.; TU, Y. Perfect and near perfect adaptation in a model of bacterial chemotaxis. Biophysical Journal, Biophysical Journal, v. 84, p. 2493-56, 2003A. Citado 2 vezes nas páginas 27 e 43 .

29 SOURJIK, V.; BERG, H. C. Receptor sensitive in bacterial chemotaxis. Proceeding of the National Academy of Sciences-PNAS, Proceeding of the National Academy of Sciences-PNAS, v. 99, p. 123-1273, 2002. Citado 2 vezes nas páginas 27 e 37.

30 MELLO, B. A.; SHAW, L.; TU, Y. Effects of receptor iteraction in bacterial chemotaxis. Biophysical Journal, Biophysical Journal, v. 87, p. 1578-1595, set 2004. Citado 2 vezes nas páginas 28 e 43. 
31 MELLO, B. A.; TU, Y. Quantitative modeling of sensitivity in bacterial chemotaxis: the role of coupling among different chemoreceptor species. Proc. Natl. Acad. Sci, Proc. Natl. Acad. Sci, p. 8223-28, 2003B. Citado na página 37.

32 DUKE, T. A. J.; BRAY., D. Heightened sensitivity of a lattice of membrane of receptors. Proc. Natl. Acad. Sci, Proc. Natl. Acad. Sci, v. 96, p. 10104-10108, 1999. Citado 4 vezes nas páginas xii, 37, 38 e 39.

33 GARCIA, S.; LUSTOSA, P.; BARROS, N. Aplicabilidade do método de simulação de monte carlo na previsão dos custos de produção de companhias industriais: $\mathrm{O}$ caso da companhia vale do rio doce. RCO - Revista de Contabilidade e Organizações FEA-RP/USP, Plos Computation Biology, v. 4, 2007. Citado 2 vezes nas páginas 45 e 46.

34 YORIYAZ, H. Método de monte carlo: princípios e aplicações na física médica. Revista Brasileira de Física Médica, Revista Brasileira de Física Médica, v. 3, p. 141-149, 2009. Citado 4 vezes nas páginas xii, 45, 46 e 47.

35 LANDAU, D. P.; BINDER, K. A Guide to Monte Carlo Simulation in Statistical Physics. EUA: [s.n.], 2005. Citado na página 46. 